\title{
1 Deformable plate tectonic models of the southern North Atlantic
}

2 Alexander L. Peace*1, J. Kim Welford ${ }^{1}$, Philip J. Ball ${ }^{2} \&$ Michael Nirrengarten $^{3}$

3

4

5

6

7

8

9

10

11

12

13

14

15

16

17

18

19

20

21

22

23

24

25

26

27

28

29

30

${ }^{1}$ Department of Earth Sciences, Memorial University of Newfoundland, St. John's, Newfoundland and Labrador, A1B 3X5, Canada

${ }^{2}$ Faculty of Natural Sciences, Geography, Geology and the Environment, William Smith Building, Keele University, Newcastle, Staffordshire, ST5 5BG, United Kingdom

${ }^{3}$ Département Géosciences et Environnement, Université de Cergy-Pontoise, Neuville-surOise, France

* Corresponding author. Email: alpeace@mun.ca

\section{Abstract}

Significant, poly-phase deformation occurred prior to, simultaneous with, and after the opening of the North Atlantic Ocean. Understanding this deformation history is essential for understanding the regional development and the mechanisms controlling rifting and subsequent failure or breakup. Here, we primarily use published constraints to construct deformable plate tectonic models for the southern North Atlantic from 200 Ma to present using GPlates. The aim of this work is to test both the capability of the GPlates deformable modelling approach and the reliability of published plate reconstructions. Overall, modelled crustal thickness values at 0 Ma produced from the deformable models show general, regional-scale, similarities with values derived from the inversion of gravity data for crustal thickness. However, the deformable models typically underestimate thinning in marginal basins and overestimate crustal thickness in continental fragments compared to values from gravity inversion. This is possibly due to: 1) thinning occurring earlier than the $200 \mathrm{Ma}$ start time modelled, 2) variations in the original crustal thickness, 3) depth-dependent stretching, 4) rigid blocks undergoing some degree of thinning, and 5) variations in the mesh density of the models. The results demonstrate that inclusion of micro-continental fragments, and locally defined limits of continental crust, generally produce results more akin to observations. One exception is the Grand Banks where global GPlates models produce more realistic deformation, likely due to the inclusion of the exhumed domains continent-ward of the transition zone boundary. Results also indicate that Flemish Cap rotation is required to provide a reasonable fit between North America and Iberia, with the paleo-position of the Flemish Cap likely to be the protoOrphan basins. Moreover, the East and West Orphan Basins formed separately due to the respective rotations of the Flemish Cap and the Orphan Knoll, which was likely associated with other continental fragments that subsequently contributed to the thicker crust forming the boundary between the East and West Orphan basins. The results also suggest a link between tectonic and magmatic processes. For example, the inclusion of an Orphan Knoll microcontinental block results in greater extension (higher beta factors) in the northern West Orphan Basin near the termination of the Charlie-Gibbs Fracture Zone, and the site of the CharlieGibbs Volcanic Province (CGVP). Thus, we infer that the CGVP was likely influenced by plate tectonic processes through the concentration of strain resulting from interaction in proximity 
40 to the transform system. Finally, marginal basins that were considered to be conjugate and thus

41 related, may only appear conjugate through later rotation of micro-continental blocks, and thus

42 their genesis is not directly related.

\section{Keywords}

44 Rifting; Magmatism; North Atlantic; Deformable plate models; GPlates; Continental breakup;

45 Tectonics; Plate Tectonic; Conjugate margins; Microplates; Rifted margins; Passive margins;

46 Continental margins; Modelling; Crustal structure; Crust; Rift

\section{Introduction}

48 The opening of the modern North Atlantic Ocean represents the final dispersal and end of the 49 Laurasia continental amalgamation that formed the northern portion of the Pangaea 50 supercontinent (Gaina et al., 2009; Hansen et al., 2009; Frizon De Lamotte et al., 2015)(Fig. 51 1). The ocean is divided into two main spreading branches; the Northeast Atlantic between 52 Greenland and Europe, and the Labrador Sea - Baffin Bay system between Greenland and 53 North America (Srivastava, 1978; Beniest et al., 2017), that form a complex junction with the 54 northeast Atlantic to the north of the Charlie-Gibbs Fracture Zone (CGFZ) (Gaina et al., 2009).

55 In addition to the primary breakup axes, complex styles of deformation occurred on the 56 continental margins, including the preservation of relatively undeformed continental fragments 57 (Peron-Pinvidic and Manatschal, 2010; Peron-Pinvidic et al., 2012; Nirrengarten et al., 2018; 58 Schiffer et al., 2018), continental transform systems (e.g., the Davis Strait; Suckro et al., 2013; 59 Peace et al., 2018a), and multiple failed rift axes (e.g., the North Sea; Rattey and Hayward, 60 1993). Despite the significant role that such deformation had upon the geological evolution of 61 the continental margins, including the prospective petroliferous basins, plate tectonic 62 reconstructions often struggle to account for much of this deformation prior to breakup (Ady 63 and Whittaker, 2018). For this reason, it is the deformation in these continental rifted margins 64 and basins, including the driving mechanisms, that form the focus of this study.

65 Here, we primarily use published constraints (e.g., Müller et al., 2016; Matthews et al., 2016; 66 Nirrengarten et al., 2018; Welford et al., 2018) to construct deformable plate tectonic models 67 for the southern North Atlantic using the open source GPlates environment (Williams et al., 68 2012a; Gurnis et al., 2018; Müller et al., 2018). We then compare the results obtained from the 69 deformable models with both geological and geophysical observations including: crustal 70 structure derived through gravity inversion (Welford et al., 2012; Roberts et al., 2018), regional 71 seismic reflection lines (e.g., Tucholke et al., 2007; Tucholke and Sibuet, 2007), the age of synrift strata in passive margin rift basins (e.g., Gouiza et al., 2016), documented inversion (e.g., Yang, 2012), and occurrences of rift-related magmatism (e.g., Keen et al., 2014). The aim of 74 this analysis was to investigate: 1) the reliability of published constraints as model components; 75 2) the reliability and applicability of the current generation of GPlates deformable models to reproduce realistic passive margin deformation, and 3) the implications for the spatio-temporal evolution of the region, including the consequences for magmatism, conjugate margin, and connected basin studies. 
81

82

83

84

85

86

87

88

89

90

91

92

93

94

95

96

97

98

99

100

101

102

103

104

105

106

107

108

109

110

111

112

113

114

115

116

117

118

119

120

121

In this study, the southern North Atlantic (Fig. 1) includes the conjugate Newfoundland-Iberia margins to the south and extends as far north as the southern Labrador Sea, southeast Greenland and the conjugate northwest European margin south of Iceland, approximately the same study area as that of Nirrengarten et al. (2018). This study area was chosen as the large-scale postbreakup plate movements are well constrained from studies of the oceanic crust (e.g., BarnettMoore et al., 2018) and pre-breakup kinematics have been derived from studies of the surrounding rifted continental margins (e.g., Hopper et al., 2003; Gouiza et al., 2016; Dafoe et al., 2017; Nirrengarten et al., 2018; Peace et al., 2018b; Peace et al., 2018c; Gouiza and Paton, 2019), which provide constraints to build models of these domains.

Prior to breakup, the proto-North Atlantic region comprised a collage of Archaean and Proterozoic terranes (Kerr et al., 1996; St-Onge et al., 2009; Štolfová and Shannon, 2009; Engström and Klint, 2014; Grocott and McCaffrey, 2017). The breakup of the North Atlantic involved multiple rift and breakup phases (Srivastava, 1978; Lundin, 2002; Oakey and Chalmers, 2012; Barnett-Moore et al., 2018; Gernigon et al., 2019). Rifting prior to breakup of the North Atlantic is documented from the stratigraphic and magmatic record to have been multi-phase, and to have occurred from the Permian, been widespread during the Triassic, and continued into the Jurassic, Cretaceous and Cenozoic (Umpleby, 1979; Larsen et al., 2009; Stoker et al., 2016; Peace et al., 2018d). Following this prolonged, region-wide rifting, opening of the Atlantic was initiated in the Central Atlantic in the Jurassic and propagated into the proto-North Atlantic in Early Aptian time (e.g., Tucholke et al., 2007; Barnett-Moore et al., 2018).

Continental breakup resulted in the genesis of the North Atlantic ocean basin separating conjugate, rifted continental passive margins (Chian et al., 1995; Eddy et al., 2017; Gernigon et al., 2019). As with passive margins globally (Geoffroy et al., 2015; Franke, 2013; Lundin et al., 2018), North Atlantic passive margins can be considered to be 'magma-poor' such as the Grand Banks-Iberia, or 'magma-rich' such as the Rockall-Hatton Bank and southeast Greenland margins. However, significant widespread rift and breakup related magmatism is also documented on the so-called 'magma-poor' margins such as on and offshore Newfoundland (Strong and Harris, 1974; Lapointe, 1979; Deemer et al., 2010; Keen et al., 2014; Peace et al., 2017b; Peace et al., 2018c; Geng et al., 2019). Whilst the NewfoundlandIberia margins are often considered as the archetypical 'magma-poor' margins (Peron-Pinvidic et al., 2007; Eddy et al., 2017; Alves and Cunha, 2018), the conjugate northern Newfoundland - Ireland conjugate pair has been the focus of fewer studies (Sinclair, 1995; Welford et al., 2012).

North Atlantic passive margins contain multiple rift basins that have attracted considerable petroleum exploration and production interest (Enachescu, 2006; Jauer et al., 2014; Alves et al., 2014; Scotchman et al., 2018; Schofield et al., 2018; Shannon, 2018), and thus it is of utmost importance that accurate plate reconstructions are produced with exploration in mind if they are to be useful in this aspect (Ady and Whittaker, 2018). In this study several of these marginal rift basins are focused on principally the Orphan Basin, offshore Newfoundland, Canada, and the Rockall and Porcupine basins, offshore the UK and Ireland, the development 
122 of which are detailed in numerous previous works and as such only the most salient points are

123 provided below.

\section{The Orphan Basin}

125 The Orphan Basin is located offshore NE Newfoundland (Figs. 1 \& 2), on a predominantly 126 non-volcanic segment of the Newfoundland passive margin (Reston, 2009). It is constrained 127 by the continental shelf to the west, the Grand Banks to the south, the micro-continental 128 fragments of the Orphan Knoll and Flemish Cap to the northeast and east, respectively and the 129 Charlie-Gibbs fracture zone to the north (Peron-Pinvidic and Manatschal, 2010; Welford et al., 130 2012; Watremez et al., 2015; Gouiza et al., 2016; Dafoe et al., 2017) (Figs. 1 \& 2). The Orphan 131 Basin is considered to comprise of East and West sub-basins, separated by the Central Orphan 132 High structure (Dafoe et al., 2017), a region comprising thicker crust (Welford et al., 2012). 133 The basin was affected by several extensional episodes between the Jurassic and the Early 134 Cretaceous, separated by events of uplift and erosion (Gouiza et al., 2016). The preserved 135 tectono-stratigraphic sequences reveal that deformation initiated in the eastern part of the 136 Orphan Basin in the Jurassic, followed by deformation in the west in the Early Cretaceous 137 (Gouiza et al., 2015; Gouiza et al., 2016). This progression resulted in syn-rift structures filled 138 with Jurassic-Lower Cretaceous syn-rift sediments that are overlain by thick Upper Cretaceous 139 to Cenozoic post-rift sequences (Gouiza et al., 2016; Dafoe et al., 2017). Crucially however, it 140 is likely the Cretaceous rifting that significantly thinned the crust and resulted in 141 hyperextension in the basin (Gouiza et al., 2015; Lau et al., 2015).

\section{The Porcupine Basin}

143 The Porcupine Basin is a deep-water sedimentary basin, located offshore to the southwest of 144 Ireland (e.g., O'Reilly et al., 2006; Watremez et al., 2018; Chen et al., 2018) (Fig. 1). Its present 145 shape and large-scale structure formed through a major episode of lithospheric stretching in 146 Jurassic times, with other rift episodes in earlier Permo-Triassic and later Early Cretaceous 147 phases (Shannon, 1991; Tate, 1993; Sinclair et al., 1994; O'Reilly et al., 2006) resulting in 148 hyperextension (Chen et al., 2018). The basin architecture is likely influenced by Caledonian 149 trends (Doré et al., 1999). Constraints on the geometry of the pre-Cenozoic successions in the 150 Porcupine Basin are poor away from the basin margins, with the Cretaceous and Mesozoic 151 successions better understood as generally unfaulted and dominated by the post-rift interval 152 (O'Reilly et al., 2006). A prominent, controversial, ridge feature has been documented in the 153 southern part of the Porcupine Basin which has been interpreted as 1) a volcanic structure (Tate 154 and Dobson, 1988; White et al., 1992; Calvès et al., 2012); 2) a serpentinite mud diapir (Reston 155 et al., 2001, 2004); or 3) a block of continental crust (Hardy et al., 2010).

157 The Rockall Basin is the sedimentary basin underlying the present day bathymetric depression 158 known as the Rockall Trough offshore of the UK and Ireland (Fig. 1). The detailed geological 159 evolution of the Rockall Basin is still largely unknown due to the lack of deep well penetrations 160 in the basin and the limited seismic data coverage, leaving the early history of this vast region 161 to be enigmatic (Tate et al., 1999; Shannon et al., 1999; Schofield et al., 2018; Roberts et al., 162 2018). Early extensional structures have been recognised, suggesting rifting initiated in the 
163 Permo-Triassic, resulting in half-graben formation, followed by further extension in the Late

164 Jurassic and Cretaceous (Doré et al., 1999; Naylor and Shannon, 2005). Igneous rocks are abundant in the Rockall Basin, particularly in the northeastern part of the basin where extensive

166 flood basalt lava flows, sill complexes and volcanic centres of Late Cretaceous-to-Early

167 Eocene age, belonging to the North Atlantic Igneous Province, have been described using 168 seismic and borehole data (Archer et al., 2005; Thomson, 2005; Magee et al., 2014). In 169 addition, the structure of the Rockall Basin is complicated further as the basin may have become hyperextended during Early Cretaceous rifting, leading to the potential for high segmentation, and a lack of Jurassic and older sequences towards the centre of the basin (Lundin and Doré, 2011). Regionally, there are similarities, including the correlation of key regional unconformities, between the Porcupine and Rockall basins, which demonstrate the similar history of these basins (McDonnell and Shannon, 2001).

\section{Approach, materials, methodology and model setup}

176 Reconstructions of the southern North Atlantic: the need for deformable plate tectonic models

Many plate tectonic models and reconstructions have been produced for the MesozoicCenozoic rifting and breakup of the North Atlantic region (Bullard et al., 1965; Rowley and

180 Lottes, 1988; Dunbar and Sawyer, 1989; Hosseinpour et al., 2013; Barnett-Moore et al., 2018; Nirrengarten et al., 2018). Each of these models inherently comes with its own assumptions, simplifications and omissions, depending on the scientific question being evaluated. Many, but not all (e.g., Whittaker, 2016; Ady and Whittaker, 2018), previous plate tectonic models for the southern North Atlantic are rigid-plate-type models and thus do not account for deformation of the continental domains prior to, during, and after breakup. The reason for this is that, although integral to deformation history, the constraints on deformation in the continental domains are much harder to obtain and less reliable compared to those from the oceanic domains such as dateable (and globally correlatable) oceanic magnetic anomalies and fracture zones (e.g., Srivastava and Roest, 1999). As such constraints do not exist for the deformed continental domains that this study seeks to reconstruct, alternative constraints must therefore be sought. Constraints on the deformation of continental domains can be obtained from 1) style and geometry of deformation including the locations of preserved continental fragments and large-scale faults, and 2) stratigraphic evidence for the timing of deformation, including riftonset and termination (Nirrengarten et al., 2018). Finally, Although a global plate model that includes deformable plates was produced by Müller et al. (2019) here we focus on modelling different scenarios for the southern North Atlantic, and focus particularly on the role of microcontinental fragments.

198 Furthermore, deformation of adjacent continental domains must be resolved such that it is in 199 agreement with the kinematics and timings of global models that have been derived from much 200 better constraints of the oceanic crust (Seton et al., 2012; Matthews et al., 2016; Müller et al., 2016). In order to deal with this latter point, the GPlates deformable modelling approach that we utilised (Gurnis et al., 2018; Welford et al., 2018; Müller et al., 2019), primarily uses the large-scale movement of plates to drive deformation, in addition to the inclusion of microcontinental fragments in some models. Finally, as constraints on continental deformation are 
much poorer, multiple scenarios must be considered, and thus modelled to evaluate their potential to accurately reproduce deformation.

207 The models presented in this work were built in GPlates 2.1 using the deformable plate 208 modelling methodology and theory described in Gurnis et al. (2018) and deployed in Welford et al. (2018) to the Baffin Bay area, to the north of the primary study area in this work. The GPlates deformable plate modelling methodology allows for deformation to occur around surrounding rigid plates (Gurnis et al., 2018). Some deformable plate tectonic models are intended to accurately restore deformed crust (e.g., Ady and Whittaker, 2018). Here, however, the models are intended to examine the influence on deformation of variable input parameters. In particular, we investigate the roles of 1) preserved micro-continental fragments, 2) various interpretations of breakup timing and geometry, and 3) the timing of basin formation through nine different models intended to investigate sensitivity to specific input parameters. In this study, models that produce more similarity at $0 \mathrm{Ma}$ with present day observations of crustal structure and deformation styles are deemed to be a better reconstruction of deformation, and thus their inputs are likely to be more accurate.

\section{General model setup}

221 We use the GPlates software (version 2.1) to conduct this investigation (e.g., Williams et al., 222 2012b; Müller et al., 2018). This open source plate tectonic modelling platform allows for a 223 variety of investigations using plate tectonic reconstructions (e.g., Phethean et al., 2016; Gion et al., 2017) including deformable models (Gurnis et al., 2018; Welford et al., 2018).

Within GPlates 'features' (i.e. points, polylines or polygons) can be defined from geological and geophysical observations (Gurnis et al., 2018). Such features, optionally including their time of appearance and/or disappearance, can be combined into a topological network (Fig. 3). A topological network is a feature whose spatio-temporal evolution is defined by the features comprising the network (Müller et al., 2016). Within this evolving network in GPlates, crustal strain accumulation can be modelled (Fig. 4), and thus estimates of crustal thickness through time can be derived. The models can account for both thickening and thinning of the crust. The full methodology and governing equations behind the GPlates deformable models are provided in Gurnis et al. (2018) and applied in Welford et al. (2018) to Baffin Bay.

Here, through a series of models, we systematically change the components comprising a topological network of the southern North Atlantic in order to investigate their influence on crustal deformation. Specifically, nine different deformable plate tectonic models for the southern North Atlantic have been built, each of which is intended to test different input parameters (Table 1 and Fig. 5). All models were run from $200 \mathrm{Ma}$ to the present (0 Ma) and assume a uniform, region-wide, crustal thickness of $30 \mathrm{~km}$ at $200 \mathrm{Ma}$, as this is within the range of values provided by previous studies (30-35 km thick) for the original crustal thickness of the Grand Banks, including the Flemish Cap (e.g. Marillier et al., 1994; Funck, 2003; Van Avendonk et al., 2009). Although widespread thinning likely occurred across the proto-North Atlantic region prior to $200 \mathrm{Ma}$, the modelled interval is taken as this time because prior to 200 Ma: 1) the reconstructions become increasingly unreliable due to the scarcity of oceanic crust, 2) the beta factors are generally too low, as there is no significant syn-rift fault heave (although 
throw may still be significant e.g., Triassic faults in Jeanne d'Arc Basin; Tankard and Welsink,

247 1987) and, 3) the age of rift phases are poorly defined due to continental or lacustrine facies

248 (Leleu et al., 2016). The implications of this assumption upon the results are discussed later in

249 this paper.

250 Although our deformable models generally use inputs taken directly from the literature, minor modifications were required in some cases to: 1) test certain aspects of the inputs and their impact upon the results, and 2) to allow the models to run and produce geologically reasonable results. Where modifications from the previous versions were either required or experimented with, they are detailed below, as are the relevant models that have been produced with the original published version for comparison (Table 1). Crustal thickness points in GPlates were created for the entire deformable network in each model with a spacing of $1.15625^{\circ}$ (GPlates density level 8) with no random offset.

\section{The continent-ward extent of deformation}

Studies of passive margins demonstrate that rift-related deformation may extend significant distances continent-ward of the first (oldest) oceanic or transitional crust (Wilson et al., 2006; Japsen et al., 2006; Ashby, 2013; Peace et al., 2018a; Peace et al., 2018c). Although such deformation generally likely decreases in magnitude continent-ward, the GPlates models require a solid boundary to denote the limits of deformation (Gurnis et al., 2018). As such, in all models presented in this work the outer limits of the topological network for the southern North Atlantic (i.e. the primary area of investigation) are taken to be the necking lines defined in Nirrengarten et al. (2018) based on the interpretation of crustal structure on seismic reflection-refraction lines and extrapolated with large-scale gravity inversion. In addition, although it is beyond the primary area of interest, the outer limits of deformation for the Baffin Bay - Labrador Sea area correspond to the $300 \mathrm{~km}$ half-width rift zone limits from Welford et al. (2018). Furthermore, the Nirrengarten et al. (2018) necking line has been extended further north along the southeast Greenland margin so that the Hatton-Rockall area could be examined. The addition of this continuation of the necking zone provides a boundary to the model but as it is not fully geologically constrained, detailed interpretation of the results on the East Greenland margin is not undertaken. The inclusion of the Baffin Bay - Labrador Sea area in addition to the southeast Greenland margin is primarily to provide a geologically reasonable northern boundary to the main study area to the south.

Finally, it should also be noted that Welford et al. (2018) found that the geometry and location of the outer limit of deformation is less important in controlling the resultant crustal thickness in the GPlates deformable models than other factors such as the timing of breakup. According to Welford et al. (2018) based on experiments with variable width of the rift zone, the main caveat is that the deformable zone needs to be wide enough so that edge effects do not have a significant influence. The continental margins defined by the topological networks were found to not be greatly influenced by edge effects and are of a similar width to those in Welford et al. (2018). 
Model 1 uses the Müller et al. (2016) continent ocean boundaries (COBs) to define the oceanward limit of continental crust, whereas Models 2-6(a-d) use the edge of continental crust (ECC) from Nirrengarten et al. (2018). The Müller et al. (2016) COBs are taken from the global compilation and include exhumed mantle (hyper-extended) domains as material continentward of the COB (e.g., on the Grand Banks, offshore Newfoundland). The Nirrengarten et al. (2018) ECC on the other hand, is defined locally in the southern North Atlantic and places the exhumed domains ocean-ward of the. As the ECC and COB were defined independently by Nirrengarten et al. (2018) and Müller et al. (2016), respectively, it is important to recognise that the criteria used to define these domains is slightly different. The intent of using these different parameters in separate models was to investigate the influence of including the exhumed domains. The ECC was used as a model input rather than the last landward oceanic crust (LaLOC) (again from Nirrengarten et al. 2018) as LaLOC also includes the exhumed domains. In some areas however (e.g., on the northwest European margin), ECC and LaLOC from Nirrengarten et al. (2018) are at the same location. The reason for ambiguity in interpretation of some areas is partially due to high volumes of igneous intrusions hindering observations (Schofield et al., 2018), the interpreted absence of coupled and exhumed mantle domains, and the presence of compression, for example in northern Iberia (e.g., Druet et al., 2018).

The original ECC from Nirrengarten et al. (2018) does not include a defined time of appearance (i.e. breakup) in the same way that the Müller et al. (2016) COBs do, as the latter were compiled for use in reconstructions. Thus, times of appearance for the Nirrengarten et al. (2018) ECC were defined as corresponding to the times when the reconstructed ECC were no longer overlapping. Breakup times defined in this way can be seen in the results and do not differ greatly (within $\sim 10$ Myrs) from the ages of breakup for the adjacent Müller et al. (2016) COBs.

As such, the following times of appearance (breakup) for the Müller et al. (2016) COBs and the ECC modified from Nirrengarten et al. (2018) were used in the models (as detailed in Table $1)$ :

- Newfoundland-Labrador margin - COBs appear at 126-110 Ma, and ECC appears at 140-120 Ma.

- Iberian margin - COBs appear at 130-124 Ma, and ECC appears at 140-120 Ma.

- Labrador Sea - COBs appear at 90-70 Ma, and ECC appears at 84-70 Ma.

- Bay of Biscay - COBs appear at $120 \mathrm{Ma}$, and ECC appears at $115 \mathrm{Ma}$.

- Southeast Greenland and conjugate Rockall-Hatton margin - COBs appear at $55 \mathrm{Ma}$, and ECC appears at 53.7-51 Ma

- Irish margin (Porcupine and southern Rockall) - COBs appear at $110 \mathrm{Ma}$ and ECC appears at 115-83 Ma.

Finally, in order to achieve a more realistic time-progressive breakup, the Nirrengarten et al. (2018) ECC was broken up into much smaller polyline segments but the geometry was not greatly changed. The only area where the geometry had to undergo a minor amendment was for the Goban Spur and northwest Iberian margin to prevent overlap in the model that would not allow the mesh to be adequately constructed. 
328 As with the majority of plate tectonic reconstructions, the GPlates environment poles of

329 rotation are defined and used to reconstruct past plate movements and positions (Gurnis et al.,

330 2012). Within the context of the models presented, it is the plate velocities derived through the 331 poles of rotation relative to one another that drive deformation (Gurnis et al., 2018). Thus, it is 332 essential that poles of rotation describe past plate motions as realistically as possible, and that 333 multiple scenarios are considered. We therefore test multiple possible poles of rotation 334 (reconstruction trees) including: 1) Matthews et al. (2016) (Model 1) 2) Nirrengarten et al. 335 (2018) (Models 2-5), and 3) new poles of rotation (this study; for the Flemish Cap, Hatton336 Rockall Bank, Porcupine bank and Orphan Knoll (Models 6a-d). The poles of rotation for the 337 micro-continental blocks, including those derived in this study, are provided in Tables 2a-d 338 and expanded upon in the subsequent sections. All features that lie on a particular plate (as defined by the GPlates static polygons; Müller et al., 2016) are rotated.

\section{1} Micro-continental blocks and fragments

It is well-acknowledged that during rifting, fragments of continental material may remain relatively undeformed whilst the surrounding areas undergo significant deformation (Lister et al., 1986; Peron-Pinvidic and Manatschal, 2010; Blischke et al., 2011; Schiffer et al., 2018). A diverse range of preserved continental fragment types can be recognised and characterised including: micro-continents (e.g., Jan Mayen Microplate Complex; JMMC, Peron-Pinvidic et al., 2012a; Peron-Pinvidic et al., 2012b; Schiffer et al., 2018; Polteau et al., 2018), continental ribbons (e.g., Flemish Cap, Rockall Bank and Galicia Bank), H-Blocks (e.g., offshore 348 Newfoundland), and extensional allochthons (e.g., ODP sites 1069, Iberian Margin) (PeronPinvidic and Manatschal, 2010).

As such, investigations into these relatively preserved fragments of continental material within the deformable rifted domain represent another significant element of the models. Nirrengarten et al. (2018) built a new regional plate tectonic reconstruction that included independent microcontinental blocks with individual temporally restricted poles of rotation. Specifically, the Nirrengarten et al. (2018) model includes polygons and temporally defined poles of rotation for the Flemish Cap, Orphan Knoll, Porcupine Bank and the Rockall-Hatton Bank. Thus, this new model allows for investigations into the development of the rift basins between these blocks of continental material during rifting to be undertaken. Furthermore, this model (i.e. Nirrengarten et al., 2018) therefore allows for a detailed investigation into the West and East Orphan, Rockall and Porcupine basins to be undertaken, where previous global reconstructions have not. In our models micro continental fragments behave as rigid blocks and retain their original (200 Ma) crustal thickness of $30 \mathrm{~km}$ throughout the modelled interval.

362 In addition to defining poles of rotation for the micro-continental blocks, the geometry of those features also had to be defined for the models. For the Flemish Cap and Porcupine Bank, the necking zone from Nirrengarten et al. (2018) was used, but as a separate feature from the main necking line (as outlined above). For the Hatton-Rockall Bank, the polygon from Nirrengarten et al. (2018) was used as a rigid block. The reason that the Rockall and Hatton Bank polygon was used rather than the necking zones was due to the many unknowns in the region, relating 
to magmatic thickening of the crust obscuring the position of the necking domains and the 369 likely influence of depth dependent stretching. For the Orphan Knoll, Model 1 uses the polygon 370 from Nirrengarten et al. (2018) whilst Models 3 and 6a-d use a smaller polygon defined based371 on the interpreted pre-rift basement on seismic reflection data (Fig. 2).

\section{Individual model specifics and motivations}

373 The input parameters for Models 1-6(a-d) are detailed in Tables 1 and 2a-d, and the initial 374 setups for these models are shown on Figure 5, whilst descriptions of the intended line of 375 investigation are provided below.

The intention of Model 1 was to investigate predictions for deformation when global constraints for poles of rotation and COBs (i.e. breakup ages) are used (Müller et al., 2016; Matthews et al., 2016). In global models of the Newfoundland and Iberian margins, the exhumed domains comprising serpentinised mantle peridotite are continent-ward of the COB. Model 1 does not include any micro-continental blocks so that their influence can also be isolated and thus assessed in the models where they are included. Model 2 was built to examine how the Nirrengarten et al. (2018) parameters would influence deformation without significant modification, whilst Model 3 is identical to Model 2 except that the geometry for the Orphan Knoll is defined using the basement horizon interpreted from seismic reflection data in the Orphan Basin (Fig. 2). Model 4 is the same as Models 2 and 3 except no micro-continental fragment for the Orphan Knoll is included. The only micro-continental fragment included in Model 5 is the Flemish Cap. The intention of Model 5 was to investigate deformation in the Orphan, Rockall and Porcupine basins in the absence of the smaller micro-continental fragments. Finally, the intention of Models 6a-d was to combine various components of the previous models (i.e. Models 1-5) that produced deformation most akin to geological and geophysical observations, in addition to experimenting with new poles of rotation that result in different configurations for the interplay between micro-continental fragments at $200 \mathrm{Ma}$.

\section{GPlates deformable modelling results}

\section{Crustal thickness, evolution, and beta factors}

395 The evolution of crustal thickness through time in all models shows general similarities as the 396 large-scale movement of the major plates (i.e. North America, Greenland, Iberia and Eurasia) are ultimately driven by similar poles of rotation (e.g., Barnett-Moore et al., 2018). However, the small (basin) scale manifestations of deformation are highly variable. Implications for this deformation form the focus of this study and are more susceptible to minor variations in model inputs such as micro-continental fragment parameters.

In this section, where appropriate, the results for particular regions have been grouped into scenarios that contain similar results, as not all aspects are varied in each model, allowing for the isolation of controlling mechanisms (Table 1). The results of the crustal thickness modelling are shown in Figures 6 and 10 for the entire modelled region, and for the Irish and Canadian margins in Figures 11 and 12, respectively. The results of the extension (beta factor) calculations for the deformable models are shown for the Irish and Canadian margins in Figures 
supplementary information. For all beta factor calculations, an initial model (200 Ma) crustal thickness of $30 \mathrm{~km}$ was assumed (Table 1).

\section{Porcupine Bank and Basin}

The region in proximity to the Porcupine Bank and Basin represents one of the areas that the different models produced highly variable results, in terms of both the final crustal thickness (0 Ma; Figs. 6 and 11) and evolution from $200 \mathrm{Ma}$ (Figs. 5-7), in addition to the calculated beta factors (Figs. 13 and 14). This demonstrates the importance of microcontinental fragments in the rift evolution of this region. Moreover, although nine models are presented in this study (Fig. 4), these only result in three significantly different scenarios for the Porcupine Basin as a result of differing amounts (or absence) of rotation of the Porcupine Bank (Table 1). For the crustal thickness in the Porcupine Basin, these are: scenario 1 (no thinning; Models 1 and 5), scenario 2 (moderate crustal thinning to approximately $20 \mathrm{~km}$ at $0 \mathrm{Ma}$; Models 2, 3 and 4), and scenario 3 (significant crustal thinning to approximately 5-15 km at $0 \mathrm{Ma}$; Models $6 \mathrm{a}, 6 \mathrm{~b}, 6 \mathrm{c}$ and 6d) (Figs. 6 and 11).

In scenario 1, with no relative movement between the Porcupine Bank and the Irish margin necking zones, no deformation occurs in the Porcupine Basin for the entire modelled interval between 200 and $0 \mathrm{Ma}$ (Figs. 6a,e, 5a,e, 6a,e and 7a,e). In such a situation, the Porcupine Basin is essentially protected from deformation elsewhere due to its unique shaped geometry, resulting in beta factors of 0 (Figs. 13a,e). In scenario 2, by $150 \mathrm{Ma}$, thinning of the crust in the Porcupine Basin is apparent, resulting in crust in the southernmost Porcupine Basin that is down to $20 \mathrm{~km}$ thick but minimal crustal thinning in the northern parts of the Porcupine Basin (Fig. 9b, c \& d). Crustal thicknesses established at $150 \mathrm{Ma}$ in scenario 2 remain unchanged until present $(0 \mathrm{Ma})$ due to the cessation of clockwise rotation of the Porcupine Bank, giving beta factors of 2-4 (Figs. 13b-e). In scenario 3, more significant rotation of the Porcupine Bank (compared to the models in scenario 2) results in much thinner crust at $150 \mathrm{Ma}$ in the Porcupine Basin of approximately 5-20 km (Fig. 9f-i). By $100 \mathrm{Ma}$ in scenario 3, thinning is widespread in the Porcupine Basin with crustal thickness generally $<15 \mathrm{~km}$ (Fig. 8f-i) and beta factors of approximately 4-6 (Fig. 13f-I, i.e. hyperextension), with regional thin-spots in the north and south depicting crustal thicknesses as low as $5 \mathrm{~km}$ (Fig. 11f-i) and beta factors of 6-8 (Fig. 13fi). In scenario 3, the crustal thicknesses (and therefore beta factors) predicted at $100 \mathrm{Ma}$ continue until present (0 Ma) (Fig. 6f-i \& 11f-i).

\section{The Orphan Basin}

As with the Porcupine Bank and Basin area (Fig. 1), the Orphan Basin (Fig. 2) represents one of the areas in this study that the different models produce highly dissimilar results, again in terms of both the final crustal thickness (0 Ma; Fig. 6 \& 12), and temporal evolution from 200 Ma (Fig. 7-8), in addition to beta factor calculations (Fig. 14). This is as a result of the focus on the role of the Orphan Knoll and Flemish Cap micro-continental fragments during rifting, and in particular their paleo-positions, geometries and trajectories to their current locations, which profoundly influenced the crustal development of the Orphan Basin.

In Model 1, at $200 \mathrm{Ma}$, it can be seen that the necking zone for the Flemish Cap overlaps with the necking zone on the Iberian margin (Fig. 4a), an unrealistic phenomena that is discussed in 
detail below. Furthermore, by $0 \mathrm{Ma}$ in Model 1, with no relative movement between the North American necking zone and the Flemish Cap, crustal thicknesses are maintained at approximately 30,25 , and $20 \mathrm{~km}$ in the southernmost, central, and northernmost Orphan Basin, respectively (Figs. 6a \& 12a), resulting in beta factors near 0 for much of the Orphan Basin (Fig. 14a). This is particularly apparent at $100 \mathrm{Ma}$ (Figs. 8a) where it can be seen that relative movement between North America and Europe results in some thinning in the outermost Orphan Basin but minimal effects towards the North American necking zone where the inner Orphan Basin is essentially protected from thinning.

457 In Model 2, the use of the more extensive Nirrengarten et al. (2018) geometry for the Orphan 458 Knoll results in crustal thickness variations in the Orphan Basin at 0 Ma from 5-25 km (Figs. $4596 \mathrm{~b} \& 12 \mathrm{~b}$ ) and beta factors of approximately 2-6 (Fig. 14b). Furthermore, a significant 460 dichotomy between the extent of deformation in the East and West Orphan sub-basins is 461 apparent in Model 2. In particular, at $0 \mathrm{Ma}$, significantly thinner crust of $<10-15 \mathrm{~km}$ is predicted in the West Orphan Basin (beta factors of 4-6) compared to the East Orphan Basin where 15$20 \mathrm{~km}$ thick crust (beta factors of 2-4) is predicted. In addition, particularly thin crust of $<5$ $\mathrm{km}$ thick (beta factors 6-8) is modelled at $0 \mathrm{Ma}$ in the northernmost West Orphan Basin. Model 2 predicts thinning of the East Orphan Basin earlier than the West Orphan Basin, which can be observed at $150 \mathrm{Ma}$ (Fig. 9b) where crust of approximately $30 \mathrm{~km}$ is still underlying the West Orphan Basin whilst the East Orphan Basin has been thinned to approximately $20 \mathrm{~km}$ thick crust. Overall, Model 2 predicts significantly thinner final (0 Ma) crustal thickness and earlier thinning in the East than the West Orphan sub-basins.

Model 3 used a smaller spatial extent for the Orphan Knoll (Figs. 2 and 4c) but the same poles of rotation as those used in Model 2 (Table 1). The result of this is that at $0 \mathrm{Ma}$, a region of crust approximately $15-20 \mathrm{~km}$ thick (beta factor $<2$; Fig. 14c) persists from the western Flemish Cap to the western limits of the Orphan Basin that is not apparent from the Model 2 results (Figs. 12c). Furthermore, the differing crustal thicknesses between the East and West Orphan sub-basins (as predicted by Model 2) are not apparent. However, the earlier thinning of East Orphan (Fig. 9c) is still apparent.

The evolution of crustal thickness in Models 4 and 5 is very similar as the inputs for the Orphan region are the same (Table 1). In Models 4 and 5, the absence of an Orphan Knoll plate (Fig. 4) and the inclusion of the Flemish Cap rotation results in more uniform crustal thicknesses across the Orphan Basin (Fig. 12d-e), with less of the small-scale manifestations of deformation observed in this region in other models (e.g., Models 2, 3 and 6a-d). In particular, at $0 \mathrm{Ma}$, crust of 10-15 km thick (beta factor approximately 4; Fig. 14d) is predicted in the northwest, with a band of crust approximately $15-20 \mathrm{~km}$ thick (beta factor predominantly $<3$; Fig. 14d) across the central Orphan Basin and a particularly thin region of crust around $5 \mathrm{~km}$ thick (beta factor approximately 6; Fig. 14d) in the southernmost Orphan Basin. of modifying the starting positions and trajectories of the Orphan Knoll and Flemish Cap is that Models 6a-6d display highly variable crustal evolution and final results, demonstrating the importance of these micro-continental fragments, as discussed below. 
491 In Model 6a, the Flemish Cap is located close to the North American margin necking zone 492 whilst the Orphan Knoll is located outboard, northwest of the Flemish cap (Fig. 4f). This 493 configuration results in extensive rapid crustal thinning from 200-150 Ma between the Orphan 494 Knoll and Flemish Cap down to $<5 \mathrm{~km}$ thickness, and crustal thinning down to $15 \mathrm{~km}$ for the 495 rest of the East Orphan Basin (Fig. 9f). By 100 Ma, Model 6a predicts crust approximately 5$49610 \mathrm{~km}$ thick (beta factor of approximately 4-6) for the majority of both the East and West 497 Orphan sub-basins, with the easternmost parts of the West and East Orphan basins displaying 498 crust $<5 \mathrm{~km}$ thick (beta factor $>15$ ), which remains the case until present (Figs. 6f, 12f \& 14f).

499 In Model 6b, the Orphan Knoll is initially located south of its position in Model 6a, west of the 500 Flemish Cap (Fig. 4g \& Table 1). The result of this configuration is that, of all the model results, 501 it is Model $6 \mathrm{~b}$ that produced the most extensive thinning across both the East and West Orphan 502 basins (Figs. 12 and 14). In particular, this extensive thinning was established by 150 Ma when 503 crust approximately 5-10 km thick (beta factor 3-6) is predicted in the East Orphan Basin (Fig. $5049 \mathrm{~g}$ ). By $100 \mathrm{Ma}$, Model $6 \mathrm{~b}$ predicts crust 5-10 km thick (beta factor 3-6) across the entirety of 505 both the East and West Orphan basins (Fig. 8g), which persists until present (Fig. 6g \& 12g).

506 The Orphan Knoll in Model 6c is again initially located west of the Flemish Cap, however, 507 both the Flemish Cap and the Orphan Knoll are not as tightly positioned next to the North 508 American margin necking zone (Fig. 4h). The result of this initial plate tectonic configuration 509 is that by $150 \mathrm{Ma}$, most of the crust in the East Orphan Basin has been thinned to $15 \mathrm{~km}$ (beta 510 factor 2), with localised areas depicting $<10 \mathrm{~km}$ thick crust (beta factor 3 ) such as south of the 511 Orphan Knoll (Fig. 9h). By 100 Ma in Model 6c, crustal thinning is more extensive in the East 512 Orphan Basin, whilst thinning in the West Orphan Basin resulted in crust of variable thickness 513 from 5-15 km thick (beta factor 2-6) (Fig. 8h), which remains the case until $0 \mathrm{Ma}$ (Fig. 6h). 514 Overall, the level of crustal thinning in Model 6c is notably lower at $150 \mathrm{Ma}$, which continues 515 to be the case until $0 \mathrm{Ma}$ (long after the cessation of extension) compared to Models $6 \mathrm{a}, \mathrm{b}$ and 516 d.

517 In Model 6d, the location of the Flemish Cap at $200 \mathrm{Ma}$ is identical to Model 6c, however, the 518 Orphan Knoll is located much closer to the Flemish Cap than the North American necking zone 519 (Fig. 4i). The result of this starting configuration is that by $150 \mathrm{Ma}$, significant crustal thinning 520 in the East Orphan Basin has occurred, locally down to $5 \mathrm{~km}$ (beta factor 6) whilst retaining 15 $521 \mathrm{~km}$ thick crust (beta factor 2) in some areas (Fig. 9i). By $100 \mathrm{Ma}$, crustal thinning in the East 522 Orphan Basin results in widespread crust of $<10 \mathrm{~km}$ thick (beta factor $<3$ ), whilst in the West 523 Orphan Basin the crustal thickness at this time is predicted to be generally $10-15 \mathrm{~km}$ (beta 524 factor 2-3), but locally $5 \mathrm{~km}$ thick (beta factor approximately 6) (Fig. 8i). This scenario persists 525 until 0 Ma (Fig. 6i \& 12i), i.e. much more extensive thinning in the East than the West Orphan 526 Basin.

527 Despite the major differences between the results of the models outlined above, some 528 similarities persist across the predictions for crustal thickness and evolution in the Orphan 529 Basin. In particular, in all models that include a separate plate for the Flemish Cap (Models 2, $5303,4,5$ and 6a-d), a region of thin crust in the southernmost East Orphan Basin (north of where 531 the Flemish Cap joins the North American Necking zone; Fig. 1) is predicted. The extent and 
geometry of this thin region varies slightly between models with this region being affected by more widespread thinning in some models (e.g., Models $6 \mathrm{~b}$ and $6 \mathrm{~d}$ ).

\section{Southern Grand Banks and Iberian Margin}

535 Although the role of the Flemish Cap and its implications for the development of the Orphan 536 Basin have been described above, this section focuses on the resultant deformation outboard 537 (east) of the Flemish Cap and to the south on the Newfoundland and the conjugate Iberian 538 margins, where again the Flemish Cap appears to have played an integral role. As with the 539 results from some of the other areas described in this section, the modelled evolution of crustal 540 deformation in this region can be considered to belong to one of multiple scenarios. These are: scenario 1 (marginal crustal thickness $<10 \mathrm{~km}$ at $0 \mathrm{Ma}$; Model 1), scenario 2 (marginal crustal thickness generally 10-15 km at $0 \mathrm{Ma}$; Models 2, 3, 4 and 5), scenario 3 (marginal crustal thickness 10-15 km and crust 25-30 km thick northeast of the Flemish Cap at $0 \mathrm{Ma}$; Model 6a and 6b), and scenario 4 (marginal crustal thickness 10-15 km and crust $20 \mathrm{~km}$ thick northeast of the Flemish Cap at $0 \mathrm{Ma}$; Model 6c and 6d).

546 In scenario 1, by $150 \mathrm{Ma}$, significant thinning of the crust on the Iberian Margin and Grand 547 Banks is predicted to result in crust 10-20 km thick, decreasing towards the south (Fig. 9a), 548 whereas in scenario 2 the crust is modelled to be typically $15-25 \mathrm{~km}$ thick, with less significant 549 along margin variation (Fig. 9c-e). In scenario 3 however, rotation of the Flemish Cap is predicted to result in significant crustal thickening to $>50 \mathrm{~km}$ on the Galicia Bank and east of the Flemish Cap (Fig. 9f-g), whilst in scenario 4, this rotation is predicted to result in crust approximately 30-35 km thick east of the Flemish Cap (Fig. 9h-i).

By 100 Ma (Fig. 8), in scenario 1, most of the Iberian and Newfoundland margins are predicted to have had crustal thicknesses generally $<10 \mathrm{~km}$ thick, whereas in scenario 2, by $100 \mathrm{Ma}$, this area is predicted to have crustal thicknesses of approximately $15 \mathrm{~km}$. In scenario 3, the crustal thickening that was apparent earlier at $150 \mathrm{Ma}$ (Fig. 9f- g) caused by the rotation of the Flemish Cap is still apparent at $100 \mathrm{Ma}$ (Fig. $8 \mathrm{f}-\mathrm{g}$ ) compared to the models where such thickening did not occur. However, this region now has a crustal thickness of 15-25 km thick. Moreover, in scenario 4, the extent of the crustal thickening caused by the rotation of the Flemish Cap is again less significant at $100 \mathrm{Ma}$ than for the scenario 3 models (Fig. 8h-i). In particular, a region of crust approximately 20-25 km thick remains east of the Flemish Cap and the crust of the northern Iberian margin (Fig. 8h-i) is slightly thicker than in the models from scenarios 2 and

563 3. For all scenarios, the crustal thicknesses at $100 \mathrm{Ma}$ (Fig. 8) persist through the entirety of the post-breakup evolution (Fig. 7) to present (Fig. 6)

\section{The Rockall-Hatton area}

566 As with the Orphan Basin and the Porcupine Basin and Bank region, the Rockall-Hatton area 567 represents one of the regions with highly variable results between models but for which 568 resultant crustal thicknesses can be considered to belong to different scenarios, for ease of 569 description. These are: scenario 1 (crustal thickness of 20-25 km at $0 \mathrm{Ma}$; Model 1), scenario 5702 (crustal thicknesses of approximately $15 \mathrm{~km}$ northwest, $5-15 \mathrm{~km}$ southwest and $20 \mathrm{~km}$ 571 southeast of Rockall-Hatton Bank at $0 \mathrm{Ma}$; Models 2, 3 and 4), scenario 3 (crustal thicknesses of generally $15-20 \mathrm{~km}$ at $0 \mathrm{Ma}$; Model 5), and scenario 4 (highly variable crustal thicknesses 
of 5-20 km thick southeast of Rockall-Hatton Bank and $20 \mathrm{~km}$ to the northwest at $0 \mathrm{Ma}$; Models 6a-d). In addition, there are some minor variations between the results for the Rockall-Hatton area in Model 6a and the other constituents of scenario 4, expanded upon below.

In scenario 1 at $150 \mathrm{Ma}$, widespread diffuse thinning, as it is not spatially restricted as Model 1, does not include a separate Hatton-Rockall Bank micro-continental fragment (Fig. 4a) to focus deformation into smaller areas such as the Rockall Basin (Fig. 9a). This scenario results in crust around $25 \mathrm{~km}$ thick (beta factor $<1$ ) for Model 1 at $150 \mathrm{Ma}$. In scenario 2 at $150 \mathrm{Ma}$, thinning is apparent in the Rockall Basin where crustal thicknesses from 20-25 km (beta factor $<1$ ) are widespread and are locally as low as $15 \mathrm{~km}$ (beta factor 2) (Fig. 9a, c \& d), whilst no thinning is yet predicted to the northwest of the Rockall-Hatton Bank micro-continental fragment. In scenario 3, crustal thickness at $150 \mathrm{Ma}$ is similar to that of scenario 1 in that the absence of a separate Hatton-Rockall Bank micro-continental fragment results in widespread diffuse thinning typically resulting in crustal thicknesses of 20-25 km (beta factor $<1$ ) (Fig. 9e). In scenario 4 at $150 \mathrm{Ma}$ (Fig. 9f-i) in the Rockall Basin (Fig. 1), much greater localisation of thinning is predicted compared to the other scenarios considered. In particular, in scenario 4 , crustal thicknesses of $<10 \mathrm{~km}$ are predicted, whilst in other parts of the Rockall Basin local crustal thicknesses of $15-25 \mathrm{~km}$ (beta factor $<1-2$ ) are predicted. Moreover, at $150 \mathrm{Ma}$ in scenario 4 in the region to the northwest of the Rockall-Hatton Bank micro-continental fragment (i.e. the southeast Greenland Margin), crustal thickening is predicted, which is described in the following section dedicated to the southeast Greenland margin.

At $100 \mathrm{Ma}$, all scenarios (1-4) produce a similar distribution of crustal thicknesses to those of $150 \mathrm{Ma}$ except that the crust is generally predicted to be thinner (Fig. 8). For example, in scenario 1 at $100 \mathrm{Ma}$, crustal thickness is around $20 \mathrm{~km}$ (beta factor $<1$ ), compared to $25 \mathrm{~km}$ thick at $150 \mathrm{Ma}$. Similarly, scenario 2 at $100 \mathrm{Ma}$ predicts crustal thicknesses around $15-20 \mathrm{~km}$, compared to $20-25 \mathrm{~km}$ thick at $150 \mathrm{Ma}$, and scenario 4 at $100 \mathrm{Ma}$ predicts crustal thicknesses of 10-20 km thick, compared to $15-25 \mathrm{~km}$ for $150 \mathrm{Ma}$. Finally, as with the $150 \mathrm{Ma}$ results, the Rockall-Hatton Bank area in scenario 3 is near identical to that of scenario 1 for $100 \mathrm{Ma}$.

At $50 \mathrm{Ma}$ (Fig. 7), the crustal thickness in the Rockall Basin is generally similar to the $100 \mathrm{Ma}$ results (Fig. 8), and as with most regions described in this result section the crustal thicknesses predicted at $50 \mathrm{Ma}$ closely resemble those at $0 \mathrm{Ma}$ (Fig. 6) for all scenarios.

\section{Labrador Sea and southeast Greenland}

Model input parameters for the Labrador Sea and southeast Greenland were not varied between models as much as for other locations in the study area as these proximal regions did not represent the primary focus of this study. Variation in model results in these regions is entirely controlled by changing input parameters elsewhere in the modelled domain. Despite this, predictions of crustal thickness for these regions do vary between model results.

On the margins of the Labrador Sea, modelled deformation is near identical in all models, and any minor variations are likely caused by varying parameters (e.g., poles of rotation) elsewhere in the modelled domain (Table 1). This is the case for both the final result (0 Ma; Fig. 6) and the evolution from $200 \mathrm{Ma}$ to this point (Figs. 7-9). Moreover, in Model 1, when the global parameters are used (Müller et al., 2016; Matthews et al., 2016) compared to those of 
614 Nirrengarten et al. (2018), the only observable difference from the results obtained in Models

$6152-6 \mathrm{~d}$ is that global constraints do not predict an area of anomalously thin crust on the northern

616 Labrador margin. Overall, at $0 \mathrm{Ma}$ (Fig. 4), all models predict crustal thickness on the margins

617 of the Labrador Sea around $15 \mathrm{~km}$ thick (beta factor of approximately 2) with some localised

618 thinning of $<10 \mathrm{~km}$ (beta factor of approximately $<3$ ) with the temporal evolution to reach this

619 point not varying significantly between models.

620 Despite not being the focus of this study, results for southeast Greenland show more variation 621 between models than those of the Labrador Sea (Fig. 6). The reason for this is that inputs for 622 the conjugate Rockall-Hatton area are intentionally varied considerably between models (Fig. 623 4), which impacts the southeast Greenland margin. First, considering the modelled crustal 624 thickness at $0 \mathrm{Ma}$, it can be seen that in Model 1, using the global constraints (Müller et al., 625 2016; Matthews et al., 2016), results in slightly thicker crust (approximately $20 \mathrm{~km}$ ) in 626 southeast Greenland for more of the margin (particularly to the south) than for Models 2-5. In 627 Models 6a-d however, when a closer fit between the Rockall-Hatton Bank and the Irish Margin 628 is used (Fig. 4f-i) compared to Models 2-5, a thicker modelled crust at $0 \mathrm{Ma}$ is predicted, 629 particularly to the north of the southeast Greenland margin. The development of this slightly 630 thicker crust on the southeast Greenland margin when a closer fit between the Rockall-Hatton 631 Bank and the Irish margin is modelled is particularly apparent at $100 \mathrm{Ma}$ (Fig. 8f-i) and 150 632 Ma (Fig. 9f-i).

633 Bay of Biscay

634 Results for the Bay of Biscay are not as variable as for other modelled regions discussed in this 635 study as this region did not represent the focus of this study in the same way that the Orphan 636 Basin and Irish margin did. In all models, by $0 \mathrm{Ma}$, significant crustal thickening in the 637 easternmost Bay of Biscay is predicted (Fig. 6). This is more apparent in Model 1 as the 638 continental margins are wider making the thicker region more extensive in area (Fig. 6). In all 639 models, crustal thickness in the Bay of Biscay increases from around $15 \mathrm{~km}$ (beta factor 2) in 640 the west to $>50 \mathrm{~km}$ (beta factor 0 ) in the east.

\section{Discussion}

\section{Comparison between deformable model results and regional observations}

643 In this section, the results of the GPlates deformable models (Figs. 6-14) are compared to 644 geological and geophysical observations from across the modelled region, principally the 645 gravity inversion results from Welford et al. (2012) (Fig. 15) but also other observations such 646 as the interpretation of seismic reflection data (e.g., Yang, 2012; Keen et al., 2014; Gouiza et 647 al., 2016). This was undertaken to test whether the various models accurately reproduced 648 deformation of the margins of the southern North Atlantic. The gravity inversion in Welford et 649 al. (2012) utilised the GRAV3D inversion algorithm ( $\mathrm{Li}$ and Oldenburg, 1996; Li and 650 Oldenburg, 1998), which is also applied in Welford et al. $(2010,2018)$.

651 The inputs for deformable models that result in features shared with real, independent 652 observations at $0 \mathrm{Ma}$ can be deemed to be candidates for attributes that may have influenced 653 the regional evolution. Furthermore, insights into which basins can be considered related are 
also possible, and are described below. The results of the gravity inversion by Welford et al. 655 (2012) are directly compared to the final results of Model 6c. Model 6c is chosen for this 656 comparison as this result is the closest (of all the deformable model results) to the crustal 657 thicknesses predicted by gravity inversion (Fig. 15).

659 Previous work has shown that the Porcupine Basin has a complex rift and post-rift history 660 (Jones et al., 2001; Reston et al., 2004; Naylor and Shannon, 2005; O'Reilly et al., 2006; Yang, 661 2012; Chen et al., 2018; Prada et al., 2018; Watremez et al., 2018). This complex rift history is 662 depicted in the results of the deformable plate tectonic models, including the prediction of 663 hyperextension.

664 Resultant crustal thicknesses derived through deformable models show general similarity with 665 the predictions of gravity inversion (Fig. 15). However, crustal thickness, both in the Porcupine 666 Basin and the Porcupine Bank, are largely over predicted in the models, which means beta 667 factors are intrinsically under predicted. The crust in the Porcupine Basin has been documented 668 to be locally as low as $2 \mathrm{~km}$ thick based on wide-angle seismic data (O'Reilly et al., 2006). 669 This is possibly because stretching, and thus thinning, had already initiated by the Permian or 670 Triassic (Štolfová and Shannon, 2009), or even as early as the Carboniferous (Tate, 1993). This 671 means that there is inherited thinning that occurred prior to the start of the modelled interval 672 from $200-0 \mathrm{Ma}$. However, given that the models are capable of producing reasonable firstorder reconstructions of deformation, this may imply that tectonic and crustal thinning prior to 674 the Jurassic was minor, or that the pre-cursory extension did not significantly alter the crustal 675 structure, perhaps because geodynamic processes remained decoupled. In addition, Chen et al. (2018) proposed following the analysis of wide-angle seismic data that the Porcupine Basin represents a propagating rift with variations in strain along the rift axis, a situation that is reproduced in our models that include a rotation of the Porcupine Bank. This suggests that such a scenario proposed by Chen et al. (2018) was likely during the early evolution of the Porcupine Basin.

681 For the Porcupine Basin and Bank, Models 6a-d produced crustal thicknesses that were most 682 comparable with those derived from gravity inversion (Welford et al., 2012) and the 683 interpretation of wide-angle seismic data (O'Reilly et al., 2006). Models 6a-d all contain significant rotation of the Porcupine Bank (Tables $1 \& 2 \mathrm{a}-\mathrm{d}$ ), implying that this phenomenon is required to explain the distribution of crustal thicknesses observed on the gravity inversion results. Moreover, Models 6a-d realistically reproduce the two crustal thin spots depicted in the gravity inversion. Regarding the two crustal thin spots, the Porcupine Basin can be divided into a northern and a southern region by the Clare Lineament (Tate, 1993). Although the models presented did not include any specific features to represent the Clare Lineament, the resultant crustal thickness maps for the Porcupine Basin in Models 6a-d show a division into northern and southern sub-basins. This perhaps implies that such a division may be a direct product of rifting, and in particular rotation of the Porcupine Bank, rather than as a result of such a discrete structure. In addition, more extensive stretching in the south of the Porcupine Basin than the north has been concluded by previous work (Watremez et al., 2018; Chen et al., 2018), which may be further evidence that rotation of the Porcupine Bank occurred. Overall, the results 
suggest that significant clockwise rotation of the Porcupine Bank is required to account for the 697 extensional deformation that resulted in the formation of the Porcupine Basin. Another 698 possibility is that the Porcupine Bank and Basin are segmented, leading to greater extension in 699 the south than the north. Geological and geophysical evidence for such segmentation has 700 however not been recognised, and thus we prefer the rotation model.

701 One of the most enigmatic features of the Porcupine Basin remains the nature and origin of the 702 Porcupine Median Ridge (e.g., Reston et al., 2004; Calvès et al., 2012). Although they do not 703 provide conclusive evidence, the results presented do indicate that stretching may have been 704 on the order capable of hyperextension (i.e. beta factors $>6$; Fig. 13), and thus a mantle 705 exhumation origin of the Porcupine Median Ridge is plausible at this location, but it does not 706 allow us to rule out other explanations such as an igneous origin, as favoured by some workers 707 (Calvès et al., 2012).

\section{Orphan Basin and Flemish Cap}

709 The Orphan Basin represents one of the areas for which the different deformable plate tectonic 710 models produce different results (Figs. 12). This is as a result of this study focusing on the 711 tectonic role and origin of the Orphan Knoll and Flemish Cap, which have proven to be integral 712 to the formation of the Orphan Basin. Overall, the results of the models show general agreement 713 with crustal thicknesses obtained from gravity inversion (Welford et al., 2012) (Fig. 15), with 714 our preferred model again being Model $6 \mathrm{c}$. In addition, the timing of deformation in the models 715 is in general agreement with geological observations, suggesting that thinning may have begun 716 earlier in the East than the West Orphan sub-basins (Gouiza et al., 2016) but that by the 717 Jurassic, rifting was documented across the Orphan Basin (Dafoe et al., 2017).

718 As significant internal deformation within the Flemish Cap is not documented by geological 719 and geophysical observations (Funck, 2003; Sibuet et al., 2007), we interpret this to be strong 720 evidence for the clockwise rotation of the Flemish Cap from a more northern position, as 721 proposed in Sibuet et al. (2007) and modelled in Models 2-6d. Models that do not include 722 rotation of the Flemish Cap and Orphan Knoll (Model 1) do not result in sufficient thinning of 723 the crust in the Orphan Basin. When no rotation of the Flemish Cap is included, there is an 724 overlap at $200 \mathrm{Ma}$ between the Flemish Cap and the Iberian margin necking zone (Fig. 4a). 725 The model that appears to reproduce the present-day structure of the Orphan Basin most closely 726 is Model 6c, but localised aspects of all models that include a rotating Flemish Cap can be seen 727 to resemble the results obtained from gravity inversion. For example, for all models that include 728 a rotation component for the Flemish Cap, a region of thin crust can be observed to the south 729 of the westernmost Flemish Cap micro-continental fragment, whilst a comparable crustal thin730 spot is also intriguingly documented on the results of the gravity inversion, perhaps a local

732 Despite the significance and necessity of Flemish Cap rotation, its rotation in Models 6a and $7336 \mathrm{~b}$ results in unrealistic deformation of Galicia Bank on the Iberian margin. This implies that 734 although rotation of the Flemish Cap is very likely required to explain the observed crustal 735 geometries of the Orphan Basin (as outlined above), perhaps the rotation is unlikely to be as 736 extensive or substantial as the scenarios modelled in Models $6 \mathrm{a}$ and $6 \mathrm{~b}$. Thus, constraints on 
the amount of rotation that the Flemish Cap may have undergone can be obtained, i.e. rotation

738 of the Flemish Cap is more likely to be comparable to the situation considered in Models 6c 739 and 6d. Overall, the results of the deformable models suggest that rotation of the Flemish Cap 740 was of comparable magnitude to that proposed in Sibuet et al. (2007) (i.e. it moved 200-300

$741 \mathrm{~km}$ southeast and rotated approximately $43^{\circ}$ with respect to Galicia Bank and Iberia).

742 In addition to providing insights into the evolution of the Flemish Cap, the results allow us to 743 make inferences regarding the origin of the Orphan Knoll. For example, in models that do not 744 include a separate Orphan Knoll micro-continental fragment, the structural division (thicker 745 crust of approximately $15-20 \mathrm{~km}$ ) observed between the East and West Orphan sub-basins in 746 the gravity inversion results (Fig. 15e) is not retained (Fig. 12a, d \& e). Moreover, this structural 747 division is also observed from seismic data, which depict a thinned crust (4-16 km thick) 748 underneath the eastern and western parts of the Orphan Basin, forming two sub-basins 749 separated by a wide structural high with a relatively thick crust (17 km thick) (Gouiza et al., 750 2016). This implies that the preservation of some thicker crust at this location during rifting 751 was likely.

752 However, as different geometries for the Orphan Knoll were considered, the model results 753 allow us to also comment upon this aspect. In particular, when the larger, more elongate 754 geometry (as proposed in Nirrengarten et al. 2018 and modelled in Model 2) was used, a 755 significant structural division between the East and West Orphan sub-basins results in the 756 prediction of greater crustal thicknesses in the central region compared to the predictions of gravity inversion. When a smaller geometry for the Orphan Knoll was used (defined using seismic basement; Fig. 2), this produces overall crustal thicknesses that are more comparable to those from gravity inversion. However, this does not produce such a clear division between 760 the East and West Orphan sub-basins. Therefore, a singular, relatively undeformed, microcontinental fragment in the region of the Nirrengarten et al. (2018) Orphan Knoll seems unlikely. Rather this region may be occupied by multiple, smaller continental crustal fragments that have undergone less deformation than crust in the adjacent East and West Orphan basins. Alternatively, this may be explained by the processes of depth-dependent stretching, which has been proposed in previous works analysing the crustal architecture of the Orphan Basin. Gouiza et al. (2016), for example, proposed a large discrepancy between brittle extension localized in the upper crust and the overall crustal thinning. A limitation of our deformable models is that they do not include depth dependant stretching (Gurnis et al., 2018). This may explain some of the local observations from the gravity inversion results. Alternatively, the simplification of the deformable domain used in these models does not properly address the localisation of spatially and temporally discrete rifting phases that may be overlapping in the Jurassic and Cretaceous rift events (e.g., Naylor and Shannon, 2005).

In addition to the geometry of the Orphan Knoll, its position at $200 \mathrm{Ma}$, and its trajectory thereafter have been shown to have a significant influence on resultant crustal deformation (Models 6a-d). The results of the deformable models indicate that the most likely position of the Orphan Knoll at $200 \mathrm{Ma}$ is near equidistant between the necking zone of the Flemish Cap and the North American margin necking zone, as this situation (Model 6c) produces a distribution of crustal thicknesses at $0 \mathrm{Ma}$ that is most comparable to the results of the gravity inversion (Fig. 15). 
780 Overall, according to the results of the deformable models, to explain the crustal evolution and 781 deformation of the Orphan Basin, relatively undeformed Orphan Knoll and Flemish Cap micro782 continental fragments are required. As such, the preferred model for the evolution of the 783 Orphan Basin is Model 6c. However, it seems plausible that some internal deformation within 784 these blocks would provide a stronger agreement between the independent results of the 785 deformable models and the gravity inversion, a situation that the modelling setup used in this 786 study (Gurnis et al., 2018) unfortunately does not allow for.

\section{Southern Grand Banks and Iberian Margin}

788 The southern Grand Banks (i.e. south of the Flemish Cap) and the conjugate Iberian margin 789 represent the only area modelled in this study where the use of the global constraints produced 790 deformation more akin to observations. In particular, Model 1 used the Müller et al. (2016) 791 continent ocean boundaries (COBs) to define the ocean-ward limit of continental crust, 792 whereas Models 2-6(a-d) used the edge of continental crust (ECC) from Nirrengarten et al. 793 (2018). The Müller et al. (2016) COBs are taken from the global compilation and include 794 exhumed mantle (hyper-extended) domains as material continent-ward of the COB (e.g., on 795 the Grand Banks, offshore Newfoundland). Conversely, the Nirrengarten et al. (2018) ECC is 796 defined locally in the southern North Atlantic and places the exhumed mantle domain ocean797 ward of the ECC. The result of including the exhumed domains in global models is that beta 798 factors more akin to hyper-extension are predicted by deformable Model 1 for this area.

799 As with the other areas considered during this work, there again appears to be more similarity 800 with the beta factor map than with crustal thickness, perhaps again suggesting that thinning 801 may have begun earlier than the modelled interval, that initial crustal thickness was less than $80230 \mathrm{~km}$, or that the mapping of the ECC or necking line was not accurate.

\section{The Rockall-Hatton area}

804 The geological evolution of the Rockall-Hatton area is well-acknowledged as being 805 particularly enigmatic due to poor seismic and well control (Tate et al., 1999; Shannon et al., 806 1999; Schofield et al., 2018; Roberts et al., 2018). It is for this reason that in our models the 807 region was included as a singular polygon (Nirrengarten et al., 2018), despite it being known 808 that the region within the polygon contains numerous basins and structures that were active 809 during rifting (Elliott and Parson, 2008). However, despite this acknowledged simplification, 810 there are many ways in which the results of the deformable models are in general agreement 811 with the predictions from the gravity inversion, given the limitations of each approach. For 812 example crustal thicknesses in the Rockall Basin from deformable Models 6a-6d are of a 813 similar magnitude to the values derived from gravity inversion (Fig. 15) and seismic data which 814 show crust in the Rockall Basin to be around $10 \mathrm{~km}$ thick in parts (Shannon et al., 1999). It is

815 for this reason that Models 6a-6d represent our preferred models for this region.

\section{Labrador Sea margins and southeast Greenland}

817 The margins of the Labrador Sea and southeast Greenland represent peripheral regions that did 818 not form the focus of this work. Thus, in order to achieve optimal results for the regions of 819 focus to the south, some unrealistic deformation may be predicted in some of the models of 
these regions. In particular, structural inversion caused by the northward movement of the

821 Rockall-Hatton Bank of the magnitude predicted in our Models 2, 3, 4 \& 6a-d is likely to be 822 unrealistic as such deformation is not documented in southeast Greenland. It is more likely that 823 deformation was accommodated within the Rockall-Hatton Bank, which was modelled as a 824 single rigid polygon (Fig. 4) despite this region containing multiple basins and structures that 825 were known to be active during rifting (Hitchen, 2004; Elliott and Parson, 2008).

\section{Bay of Biscay}

827 On the margins of the Bay of Biscay, the models predict significant crustal thinning in the west $828(\sim 10-15 \mathrm{~km})$ and thickening to the east, where crustal thickness may exceed $40 \mathrm{~km}$ (Fig. 6). 829 The unrealistic crustal thickening may indicate that the poles of rotation in this region require 830 further modification. However, the Bay of Biscay was not the focus of this work, which as 831 outlined previously focused on the Canadian and Irish margins. As such future work should 832 seek to further constrain the tectonic history of this region, including the role of oblique 833 extension and the poles of rotation for any micro-continental fragments.

\section{Compression and inversion of the passive margins of the southern North Atlantic}

835 Compression is indicated at numerous locations, in many of the results of the deformable 836 models. For example, in proximity to the rotating micro-continental fragments it is common 837 (e.g., east of Flemish Cap and west of Porcupine Bank; Models 6a-d at 150 Ma Fig. 9f-i). In 838 addition, more significant thickening due to compression is predicted in the Pyrenean region 839 in all models, which can be observed by $100 \mathrm{Ma}$ (Fig. 8) and is retained until present (Fig. 6). 840 This compression is to be expected in passive margin basins and adjacent regions (Cloetingh 841 et al., 2008). Comparison with regional observations shows that these predictions are 842 reasonable, as inversion of marginal basins is a commonly documented phenomena in the 843 region (Doré et al., 1996; Tate et al., 1999; Yang, 2012; Cadenas et al., 2018; Druet et al., 844 2018).

845 For example, in the northern Porcupine Basin it has been demonstrated (using seismic 846 reflection data) that Late Jurassic-Early Cretaceous compression likely occurred (Yang, 2012). 847 In addition, more recent inversion is observed of Cenozoic age from across the European 848 northeast Atlantic margin, including; domes, anticlines, reverse faults and broad-scale 849 inversions (Doré et al., 1996; Doré et al., 2008). Our models predict the Late Jurassic-Early 850 Cretaceous compression documented in the northern Porcupine Basin (Yang, 2012), and even 851 allow us to suggest the cause of this deformation being the rotation of the Porcupine Bank. 852 However, our models do not predict the more recent Cenozoic inversion as much of this occurs 853 post-breakup, and through mechanisms that cannot be expressed through the GPlates 854 deformable plates workflow (Gurnis et al., 2018), such as far-field orogenic stress or 855 breakup/spreading forces such as ridge push (Doré et al., 2008).

856 Further south, on the Iberian margin, previous work also documents compression in the Bay of 857 Biscay and Pyrenees region due to the kinematics of the Iberian Plate (Vissers and Meijer, 858 2012a; Vissers and Meijer, 2012b). Significant crustal thickening due to compression is 859 predicted by our models of this region, in line with these regional observations. However, the 860 kinematics of the Iberian plate, and thus the opening mechanism of the Bay of Biscay, remain 
861 a subject of debate (Tavani et al., 2018). Therefore, although our models also predict this

862 deformation, as we have not explicitly experimented with different opening scenarios for the

863 Bay of Biscay we are not able to make significant inferences regarding the mechanisms 864 involved.

865 The Newfoundland margin has also been found by previous work to exhibit evidence of 866 compression compatible with observations in our models (Grant, 1987; Enachescu, 2006; Lau 867 et al., 2006). Further north, on the Labrador Margin, Dickie et al. (2011) documented structural 868 inversion on seismic data of Coniacian age, which is not predicted by our models. Moreover, 869 structural inversion to the north of the present study area in the Davis Strait and Baffin Bay 870 region is widespread (Oakey and Chalmers, 2012; Gion et al., 2017; Peace et al., 2018c). 871 Although, our modelled domain does not extend to these latter regions these observations 872 demonstrate that marginal compression is a widespread and significant event across the North 873 Atlantic region.

\section{Summary of comparison between modelling results and observations}

875 Overall, the deformable plate tectonic models presented have reproduced deformation at $0 \mathrm{Ma}$ 876 that is in many ways comparable to observations made on the margins of the southern North 877 Atlantic, given the limitations of the regional geological understanding and modelling 878 approach. In particular, Model 6c appears to produce crustal thickness values comparable to 879 those derived from gravity inversion for more regions than the other models. Thus, we deem 880 Model $6 \mathrm{c}$ to be the best reconstruction of micro-continental fragments of all models presented 881 herein. However, even within the results of this best approximation model, several regions still 882 depict discrepancies from regional geological and geophysical observations. In particular, such 883 areas include: the margins of the Bay of Biscay, southeast Greenland and the Rockall-Hatton 884 Bank area.

\section{Implications for conjugate margin studies}

886 It is well-acknowledged and documented that in order to fully comprehend rift evolution, and 887 thus the large-scale processes driving deformation, both conjugate margins must be studied 888 (Lister et al., 1986; Chian et al., 1995; Welford et al., 2012; Ball et al., 2013; Louden et al., 889 2013; Gernigon et al., 2015; Peace et al., 2016). However, the inclusion of rotating, 890 independent, micro-continental fragments within the rift (as examined in this study) has 891 profound implications for conjugate margin studies (Sibuet et al., 2007; Nirrengarten et al., 892 2018). The reason for this is that margin segments that today look as if they are conjugate did 893 not originally form as conjugates. In fact they are pseudo-conjugates that have been translated 894 into locations with orientations that appear conjugate due to poly-phase rifting and the 895 formation and subsequent rotation of micro-continental blocks. This is particularly true for 896 micro-continental blocks that have undergone a significant rotation or along margin movement 897 such as the Flemish Cap (Sibuet et al., 2007). Regarding the Flemish Cap, in our preferred 898 model (Model 6c), we interpret that the northeastern Flemish Cap was conjugate to the 899 Porcupine Bank, whilst the southwest Flemish Cap was conjugate to the Goban Spur and 900 Galicia Bank (Fig. 4h). Thus, some 'conjugate margin' studies may be overly simplistic in 901 areas such as the southern North Atlantic where multiple, disparate continental fragments may 
902

903

904

905

906

907

908

909

910

911

912

913

914

915

916

917

918

919

920

921

922

923

924

925

926

927

928

929

930

931

932

933

934

935

936

937

938

939

940

941

942

have originally been part of the same rift system. The situation can be further complicated in areas such as this area which contain triple junctions (i.e. extinct Labrador Sea spreading axis joining the main North Atlantic axis; e.g., Srivastava, 1978), in addition to rift axes that failed to achieve breakup e.g., Rockall Basin (Joppen and White, 1990).

An example of this type of ambiguity in the studied region is determining which parts of the East and West Orphan basins on the Canadian Margin can be considered conjugate to the Porcupine or Rockall Basins on the Irish Margin (Skogseid, 2010). Some previous reconstructions place East Orphan Basin conjugate to Porcupine Basin and West Orphan Basin conjugate to Rockall Basin. However, according to the reconstruction of Nirrengarten et al. (2018), as used in the models described, the Rockall Basin may not be conjugate to West Orphan and, furthermore, the Rockall Basin might be more akin to East Orphan and the Porcupine Basin may not be conjugate to either the West or East Orphan basins. Overall, due to the complications of determining precisely which basins and margin segments were conjugate in the rift, we suggest describing candidate basins as connected basins rather than conjugate margins or basins. Future work should seek to determine which, if any, of the Irish and Eastern Canadian offshore basins can be considered connected or related.

\section{Implications for local and regional magmatic evolution}

The interplay between extensional tectonic processes and magmatism represents one of the most studied and debated topics within the Earth sciences (White and McKenzie, 1989; White, 1992; Foulger and Anderson, 2005; Larsen et al., 2009; Foulger et al., 2015; Peace et al., 2016; Peace et al., 2017a; Petersen et al., 2018; Clarke and Beutel, 2019). The results of the models presented herein allow us to compare predictions of the timing and extent of significant crustal deformation with dated occurrences of igneous rocks (e.g., Hansen et al., 2009; Keen et al., 2014; Wilkinson et al., 2016; Á Horni et al., 2017). Thus, they allow us to test the potential role of plate tectonic processes in the development of rift-related magmatism. However, without careful consideration of the model input parameters, they do not allow us to discern between different mechanisms, i.e. the difference between active and passive rifting (e.g., Geoffroy, 2005; Franke, 2013; Geoffroy et al., 2015). In addition, there are factors that may also exert some control on magmatism such as inherited mantle fertility or re-fertilization as necking and exhumation processes evolve (e.g., Picazo et al., 2016) and also potential temperatures (Nielsen, 2002), that our models do not allow us to comment upon directly.

\section{Charlie-Gibbs Volcanic Province}

The Charlie-Gibbs Volcanic Province (CGVP) is a magmatic province documented from seismic data in the northern West Orphan Basin, near the western termination of the CharlieGibbs Fracture Zone (CGFZ) (Pe-Piper et al., 2013; Keen et al., 2014). The CGVP comprises a suite of seamounts and flows (Keen et al., 2014), and can be considered as part of a sequence of Mesozoic-Cenozoic rift-related magmatism on the Newfoundland Margin (Pe-Piper et al., 1992; Pe-Piper et al., 2007; Peace et al., 2018c). Keen et al. (2014) stratigraphically dated the CGVP as Mid-Late Cretaceous, and postulated that the emplacement of these magmatic rocks may have been related to transtensional movements on the CGFZ, i.e. a significant kinematic, plate tectonic control on magmatism. However, although a Late Cretaceous age is credible in 
943 the regional geological context, it should be considered approximate due to the sparse well

944 control in the northern West Orphan Basin.

945 The deformable results show that in models where a separate plate is included for the Orphan

946 Knoll, there is a rapid thinning of the crust, and therefore high beta factors, at the location of

947 the CGVP during the interval ca. $80-120 \mathrm{Ma}$ (Figs. 7-10, and 15), i.e. at a similar time to the

948 emplacement of the CGVP (Keen et al., 2014). Thus, it appears that the modelling results

949 provide evidence in support of the formation mechanism proposed by Keen et al. (2014).

950 Moreover, the results indicate that the Orphan Knoll is integral to the evolution of the Orphan

951 Basin and surrounding area, and further justify its inclusion as a separate plate in models (i.e.

952 Nirrengarten et al., 2018).

953 The results of the models herein are intriguingly similar to the predictions of the numerical 954 models by Beutel (2005) who also predicted stress concentrations at ridge-transform955 intersections that could result in adiabatic melting and thus seamount formation. In addition, 956 the numerical modelling of Ammann et al. (2017) suggests that rift obliquity plays a significant 957 role in the formation of large oceanic fracture zones such as the CGFZ, potentially providing 958 further evidence that the CGFZ underwent significant oblique extension. Finally, given that 959 oceanic transforms have been suggested to form at the locations of major pre-existing 960 structures, a link between tectonic and magmatic processes seems plausible, with such barriers 961 to rifting being associated with magmatism elsewhere in both numerical models (Koopmann 962 et al., 2014) and geological observations (Peace et al., 2017a).

963 Finally, however, many other factors are known to influence magmatism. Such factors include 964 mantle fertility (Foulger et al., 2005; Foulger and Anderson, 2005; Shorttle et al., 2014; Picazo 965 et al., 2016), and also possibly thermal anomalies (White and McKenzie, 1989; Geldmacher et 966 al., 2005), neither of which can be ruled out as either dominant or complementary factors based 967 on the model results.

\section{Limitations of the GPlates deformable models methodology}

969 Here, we have applied the GPlates deformable modelling methodology described in Gurnis et 970 al. (2018) to the passive margins and rift basins of the southern North Atlantic region (Fig. 1). 971 Whilst comparison of our results with other, independent predictions of crustal thickness and 972 structure shows general, large-scale similarity, there remain disparities that can be largely 973 explained due to the limitations of this methodology. However, through recognition of the 974 limitations of the methodology, we are able to discern the most important aspects of the 975 kinematic evolution of the North Atlantic, including the potential controlling mechanisms.

976 First, the methodology utilised herein requires the assumption that at the start of the model, the 977 crust is homogeneous and of uniform thickness. However, even if the models were capable of 978 starting with a heterogeneous crust of variable thickness, realistically predicting such 979 parameters (e.g., thickness, strength, pre-existing heterogeneity) would likely prove 980 problematic, and possibly introduce further uncertainties.

981 In addition, starting the models at $200 \mathrm{Ma}$ likely also influenced the final results. The reason 982 for this is that regional stretching, or even rifting, likely occurred prior to $200 \mathrm{Ma}$ (Stoker et 
al., 2016). This means that the crustal thickness at $200 \mathrm{Ma}$ was likely highly variable, which is not accounted for in the models. However, given that comparable results, given this limitation are produced, this perhaps implies that crustal thinning prior to $200 \mathrm{Ma}$ was insignificant at the scale considered in this work.

987

988

989

990

991

992

993

994

995

996

997

998

999

1000

1001

1002

1003

1004

1005

1006

1007

1008

1009

1010

1011

1012

1013

1014

1015

1016

1017

1018

1019

1020

1021

1022

1023

1024
Another assumption of the modelling approach that is likely to have had an impact upon the results is that the model setup requires the boundaries to the deformable domain to be 'hard', i.e., deformation cannot diffuse into the surrounding undeformed continent, and overlapping rift events cannot be modelled, which has been shown to be the case in the region (e.g., Porcupine Basin - Bulois et al., 2018). This means that domains of the model have to be selected to be either deformable or non-deformable, i.e. one cannot define regions that are only deformable for part of the modelled interval. The result of this is that it is not possible to implement a scenario in which a particular domain, for example a microcontinental fragment, undergoes some thinning but not as much as surrounding regions. Moreover, another aspect of the hard model boundaries is that they may have introduced edge effects. Although the influence of edge effects appears to be relatively minor, edge effects may be influential in areas of oblique extension (such as the Pyrenees). Of all model limitations, the results presented herein suggest that the hard model boundaries may have had the most significant influence upon resultant crustal thicknesses, and thus calculated beta factors.

The initial location, geometry of the model inputs (Fig. 4), as well as the subsequent trajectory as determined by the poles of rotation (Tables 1-2a-d) influence the results. This is demonstrated through the highly variable results produced in Models 1-6c, which use different inputs. It is not only plausible, but likely, that some of the discrepancies between model results and real-world observations can be explained due to ambiguity in the model inputs. Our results presented herein (as well as preliminary experiments also conducted) suggest that of particular importance is the reconstructed position of the ECC as well as the timing of breakup. Future work should focus on better constraining these aspects to build on the models presented herein.

Another consideration is that as with other areas considered, the Rockall Basin likely underwent depth dependant differential stretching (Shannon et al., 1999) and our models, based on Gurnis et al. (2018), do not account for this. In particular, it is claimed that in the Rockall Basin, the upper crust has been thinned by a stretching factor of 8-10 while the middle and lower crust (and probably also the lithospheric mantle) were stretched by a factor of 2-3 (Shannon et al., 1999). This could explain some of the discrepancies between the deformable model results and the predictions of crustal thickness obtained from gravity inversion, although the more dominant influence upon the results is likely to be the lack of internal deformation within the modelled Rockall-Hatton Bank polygon, where rifting is documented (Hitchen, 2004; Elliott and Parson, 2008).

Finally, the assumption of symmetrical, depth-uniform, pure-shear deformation is likely to have also had an influence upon the final model results. For example, previous work has proposed that simple shear-type deformation may have been dominant in the Porcupine Basin (Reston et al., 2001; O'Reilly et al., 2006) and Labrador Sea (Peace et al., 2016), where observations of asymmetric basin fill and crustal geometry as well as detachments have been reported. However, despite the outlined simplification of the models, the application of pure 
1025

1026

1027

1028

1029

1030

1031

1032

1033

1034

1035

1036

1037

1038

1039

1040

1041

1042

1043

1044

1045

1046

1047

1048

1049

1050

1051

1052

1053

1054

1055

1056

1057

1058

1059

shear, symmetric, depth uniform thinning does appear to successfully manage to replicate the first-order crustal structure, and thus allows for differentiation between the geodynamic scenarios modelled (Fig. 4). This perhaps implies that at the scale considered in this study, rifting can be assumed to approximate pure shear-type deformation (e.g., McKenzie, 1978).

\section{Conclusions}

A suite of deformable plate tectonic models based on published constraints for the southern North Atlantic has been created in GPlates. The purpose was to test the viability of the GPlates deformable modelling approach, the published model inputs, and the influence of various prerift configurations. The conclusions of this study are as follows:

1) The GPlates deformable modelling tool has proven to be an effective means of testing different scenarios for the tectonic development of the southern North Atlantic.

2) Inclusion of micro-continental fragments, and more locally defined limits of continental crust, in deformable models, generally produces results more akin to observations, with the exception of the Grand Banks where global models produce more realistic deformation. This is likely due to the inclusion of the hyper-extended domains (coupled and exhumed) as continental material in such global models.

3) New poles of rotation for the Porcupine Bank, Orphan Koll, Flemish Cap and the Rockall-Hatton Bank produce deformation more akin to geological and geophysical observations.

4) Rotation of the Flemish Cap is unequivocally required to provide a geologically reasonable fit between North America and Iberia, with the paleo-position of the Flemish Cap in the proto-Orphan Basin producing reasonable estimates of crustal deformation given modelling limitations.

5) A smaller, refined geometry of the Orphan Knoll (after Nirrengarten et al. 2018) is probably more representative. However, this produces some unrealistic predictions for the crustal evolution of the Orphan Basin and thus smaller continental fragments may exist in the vicinity of the Nirrengarten et al. (2018) Orphan Knoll polygon.

6) Inclusion of the Orphan Knoll in models results in higher modelled beta factors in the northern West Orphan Basin near the termination of the CGFZ, and the site of the CGVP. Thus, we infer that the CGVP was potentially influenced by plate tectonic processes, with the Orphan Knoll probably being related.

7) The East and West Orphan basins formed separately due to the respective rotations of the Flemish Cap and the Orphan Knoll, which was likely associated with other continental fragments that subsequently contributed to the formation of the region of thicker crust between the East and West Orphan basins. 
8) Basins that were considered to be conjugate, and thus strongly related, may in fact only have been brought into positions that appear to be conjugate through later rotation of micro-continental blocks, and thus their genesis is not as related as previously inferred.

\section{Acknowledgements}

1064 Alexander L. Peace's postdoctoral fellowship at Memorial University of Newfoundland was 1065 funded by the Hibernia Project Geophysics Support Fund and Innovate NL. We would like to 1066 thank the GPlates development and maintenance team and the members of the MAGRiT group 1067 at Memorial University of Newfoundland for valuable scientific discussions. We would also 1068 like to acknowledge TGS for the generous provision of the seismic reflection data from the 1069 Orphan Basin. To prevent visual distortion of the data, most figures in this manuscript use 1070 perceptually uniform colour palettes from the Scientific Colour Maps collection for which we 1071 acknowledge Crameri (2018). Finally, we would like to thank the two anonymous reviewers 1072 for their constructive comments that greatly helped to improve this manuscript. 


\section{References}

1075

1076

1077

1078

1079

1080

1081

1082

1083

1084

1085

1086

1087

1088

1089

1090

1091

1092

1093

1094

1095

1096

1097

1098

1099

1100

1101

1102

1103

1104

1105

1106

1107

1108

1109

1110

1111

1112

1113

Á Horni, J., Hopper, J.R., Blischke, A., Geisler, W.H., Stewart, M., McDermott, K., Judge, M., Erlendsson, Ö., and Árting, U., 2017, Regional distribution of volcanism within the North Atlantic Igneous Province: Geological Society, London, Special Publications, v. 447, no. August, p. SP447.18, doi: 10.1144/SP447.18.

Ady, B.E., and Whittaker, R.C., 2018, Examining the influence of tectonic inheritance on the evolution of the North Atlantic using a palinspastic deformable plate reconstruction: , doi: $10.1144 / \mathrm{SP} 470.9$.

Alves, T.M., Bell, R.E., Jackson, C.A.L., and Minshull, T.A., 2014, Deep-water continental margins: Geological and economic frontiers: Basin Research, v. 26, no. 1, p. 3-9, doi: 10.1111/bre.12053.

Alves, T.M., and Cunha, T.A., 2018, A phase of transient subsidence, sediment bypass and deposition of regressive-transgressive cycles during the breakup of Iberia and Newfoundland: Earth and Planetary Science Letters, v. 484, p. 168-183.

Ammann, N., Liao, J., Gerya, T., and Ball, P., 2017, Oblique continental rifting and long transform fault formation based on $3 \mathrm{D}$ thermomechanical numerical modeling: Tectonophysics, doi: 10.1016/j.tecto.2017.08.015.

Archer, S.G., Bergman, S.C., Iliffe, J., Murphy, C.M., and Thornton, M., 2005, Palaeogene igneous rocks reveal new insights into the geodynamic evolution and petroleum potential of the Rockall Trough, NE Atlantic Margin: Basin Research, v. 17, no. 1, p. 171-201, doi: 10.1111/j.1365-2117.2005.00260.x.

Ashby, D., 2013, Influences on continental margin development: a case study from the Santos Basin, South-eastern Brazil: Durham University E-Theses,.

Van Avendonk, H.J.A., Lavier, L.L., Shillington, D.J., and Manatschal, G., 2009, Extension of continental crust at the margin of the eastern Grand Banks, Newfoundland:

Tectonophysics, v. 468, no. 1-4, p. 131-148, doi: 10.1016/j.tecto.2008.05.030.

Ball, P., Eagles, G., Ebinger, C., McClay, K., and Totterdell, J., 2013, The spatial and temporal evolution of strain during the separation of Australia and Antarctica: Geochemistry, Geophysics, Geosystems, v. 14, no. 8, p. 2771-2799, doi: 10.1002/ggge.20160.

Barnett-Moore, N., Müller, R.D., Williams, S., Skogseid, J., and Seton, M., 2018, A reconstruction of the North Atlantic since the earliest Jurassic: Basin Research, v. 30, p. 160-185, doi: 10.1111/bre.12214.

Beniest, A., Koptev, A., Leroy, S., Sassi, W., and Guichet, X., 2017, Two-branch break-up systems by a single mantle plume: Insights from numerical modeling: Geophysical Research Letters, doi: 10.1002/2017GL074866.

Beutel, E.K., 2005, Stress-induced seamount formation at ridge-transform intersections: Geological Society of America Special Papers, v. 2388, no. 34, p. 581-593, doi: $10.1130 / 2005.2388(34)$.

Blischke, A., Arnarson, T.S., and Gunnarsson, K., 2011, The Structural History of the Jan 
Mayen Micro-Continent ( JMMC ) and Its Role During the Rift " J ump " Between the Aegir to the Kolbeinsey Ridge *, in AAPG, 3P Arctic-The Polar Petroleum Potential Conference \& Exhibition, extended Abstract, Halifax, Nova Scotia, Canada,.

Bullard, E., Everett, J.E., and Smith, A.G., 1965, The Fit of the Continents around the Atlantic: Philosophical Transactions of the Royal Society A: Mathematical, Physical and Engineering Sciences, v. 258, no. 1088, p. 41-51, doi: 10.1098/rsta.1965.0020.

Bulois, C., Pubellier, M., Chamot-Rooke, N., and Watremez, L., 2018, From orogenic collapse to rifting: A case study of the northern Porcupine Basin, offshore Ireland: Journal of Structural Geology, v. 114, p. 139-162.

Cadenas, P., Fernández-Viejo, G., Pulgar, J.A., Tugend, J., Manatschal, G., and Minshull, T.A., 2018, Constraints Imposed by Rift Inheritance on the Compressional Reactivation of a Hyperextended Margin: Mapping Rift Domains in the North Iberian Margin and in the Cantabrian Mountains: Tectonics, v. 37, no. 3, p. 758-785, doi: 10.1002/2016TC004454.

Calvès, G., Torvela, T., Huuse, M., and Dinkleman, M.G., 2012, New evidence for the origin of the Porcupine Median Volcanic Ridge: Early Cretaceous volcanism in the Porcupine Basin, Atlantic margin of Ireland: Geochemistry, Geophysics, Geosystems, v. 13, no. 6, p. 1-18, doi: 10.1029/2011GC003852.

Chen, C., Watremez, L., Prada, M., Minshull, T., Edwards, R., O’Reilly, B., Reston, T., Wagner, G., Gaw, V., Klaschen, D., and Shannon, P., 2018, From Continental Hyperextension to Seafloor Spreading: New Insights on the Porcupine Basin from Wide-angle Seismic Data: Journal of Geophysical Research: Solid Earth, doi: 10.1029/2018JB016375.

Chian, D., Keen, C., Reid, I., and Louden, K.E., 1995, Evolution of nonvolcanic rifted margins: new results from the conjugate margins of the Labrador Sea: Geology, v. 23, no. 7, p. 589-592, doi: 10.1130/0091-7613(1995)023<0589:EONRMN>2.3.CO;2.

Clarke, D.B., and Beutel, E.K., 2019, Davis Strait Paleocene Picrites: Products of a Plume or Plates? Earth-Science Reviews, doi: 10.1016/j.earscirev.2019.01.012.

Cloetingh, S., Beekman, F., Ziegler, P.A., van Wees, J.-D., and Sokoutis, D., 2008, Post-rift compressional reactivation potential of passive margins and extensional basins: Geological Society, London, Special Publications, v. 306, no. 1, p. 27-70, doi: 10.1144/sp306.2.

Crameri, F., 2018, Geodynamic diagnostics, scientific visualisation and StagLab 3.0: Geoscientific Model Development, v. 11, no. 6, p. 2541-2562, doi: 10.5194/gmd-112541-2018.

Dafoe, L.T., Keen, C.E., Dickie, K., and Williams, G.L., 2017, Regional stratigraphy and subsidence of Orphan Basin near the time of breakup and implications for rifting processes: Basin Research, v. 29, p. 233-254, doi: 10.1111/bre.12147.

Deemer, S., Hurich, C., and Hall, J., 2010, Post-rift flood-basalt-like volcanism on the Newfoundland Basin nonvolcanic margin: The U event mapped with spectral decomposition: Tectonophysics, v. 494, no. 1-2, p. 1-16, doi: 10.1016/j.tecto.2010.07.019. 
Dickie, K., Keen, C.E., Williams, G.L., and Dehler, S.A., 2011, Tectonostratigraphic evolution of the labrador margin, atlantic canada: Marine and Petroleum Geology, v. 28, no. 9, p. 1663-1675, doi: 10.1016/j.marpetgeo.2011.05.009.

Doré, A.G., Lundin, E.R., Doré, A.G., and Lundin, E.R., 1996, Cenozoic compressional structures on the NE Atlantic margin; nature, origin and potential significance for hydrocarbon exploration: Petroleum Geoscience, v. 2, no. 4, p. 299-311, doi: 10.1144/petgeo.2.4.299.

Doré, A.G., Lundin, E.R., Jensen, L.N., Birkeland, Ø., Eliassen, P.E., and Fichler, C., 1999, Principal tectonic events in the evolution of the northwest European Atlantic margin: Petroleum Geology of Northwest Europe: Proceedings of the 5th Conference, v. 5, p. 41-61, doi: 10.1144/0050041.

Doré, A.G., Lundin, E.R., Kusznir, N.J., and Pascal, C., 2008, Potential mechanisms for the genesis of Cenozoic domal structures on the NE Atlantic margin: pros, cons and some new ideas: Geological Society, London, Special Publications, v. 306, no. 1, p. 1-26, doi: 10.1144/SP306.1.

Druet, M., Muñoz-Martín, A., Granja-Bruña, J.L., Carbó-Gorosabel, A., Acosta, J., Llanes, P., and Ercilla, G., 2018, Crustal structure and continent-ocean boundary along the Galicia continental margin (NW Iberia): insights from combined gravity and seismic interpretation: Tectonics, v. 37, no. 5, p. 1576-1604.

Dunbar, J.A., and Sawyer, D.S., 1989, Patterns of continental extension along the conjugate margins of the central and North ATLANTIC Oceans and Labrador Sea: Tectonics, v. 8, no. 5, p. 1059-1077, doi: 10.1029/TC008i005p01059.

Eddy, M.P., Jagoutz, O., and Ibañez-Mejia, M., 2017, Timing of initial seafloor spreading in the Newfoundland-Iberia rift: Geology, v. 45, no. 6, p. G38766.1, doi: 10.1130/G38766.1.

Elliott, G.M., and Parson, L.M., 2008, Influence of margin segmentation upon the break-up of the Hatton Bank rifted margin, NE Atlantic: Tectonophysics, v. 457, no. 3-4, p. 161176, doi: 10.1016/j.tecto.2008.06.008.

Enachescu, M.E., 2006, Structural Setting and Petroleum Potential of the Orphan Basin, offshore Newfoundland and Labrador: Canadian Society of Exploration Geophysicists Recorder, v. 31, no. 2, p. 5-13.

Engström, J., and Klint, K., 2014, Continental Collision Structures and Post-Orogenic Geological History of the Kangerlussuaq Area in the Southern Part of the Nagssugtoqidian Orogen, Central West Greenland: Geosciences, v. 4, p. 316-334, doi: 10.3390/geosciences4040316.

Foulger, G.R., and Anderson, D.L., 2005, A cool model for the Iceland hotspot: Journal of Volcanology and Geothermal Research, v. 141, no. 1-2, p. 1-22, doi: 10.1016/j.jvolgeores.2004.10.007.

Foulger, G.R., Christiansen, R.L., and Anderson, D.L., 2015, The Yellowstone "hot spot" track results from migrating basin-range extension: Geological Society of America Special Paper, v. 514, no. 514, p. SPE514-14, doi: 10.1130/2015.2514(14). 
Foulger, G.R., Natland, J.H., and Anderson, D.L., 2005, A source for Icelandic magmas in remelted Iapetus crust: Journal of Volcanology and Geothermal Research, v. 141, no. 12, p. 23-44, doi: 10.1016/j.jvolgeores.2004.10.006.

Franke, D., 2013, Rifting, lithosphere breakup and volcanism: Comparison of magma-poor and volcanic rifted margins: Marine and Petroleum Geology, v. 43, no. 0, p. 63-87, doi: 10.1016/j.marpetgeo.2012.11.003.

Frizon De Lamotte, D., Fourdan, B., Leleu, S., Leparmentier, F., and De Clarens, P., 2015, Style of rifting and the stages of Pangea breakup: Tectonics, v. 34, no. 5, p. 1009-1029, doi: 10.1002/2014TC003760.

Funck, T., 2003, Crustal structure of the ocean-continent transition at Flemish Cap: Seismic refraction results: Journal of Geophysical Research, v. 108, no. B11, p. 2531, doi: 10.1029/2003JB002434.

Gaina, C., Gernigon, L., and Ball, P., 2009, Palaeocene-Recent plate boundaries in the NE Atlantic and the formation of the Jan Mayen microcontinent: Journal of the Geological Society, v. 166, no. 4, p. 601-616, doi: 10.1144/0016-76492008-112.

Geldmacher, J., Hoernle, K., Bogaard, P. V.D., Duggen, S., and Werner, R., 2005, New40Ar39Ar age and geochemical data from seamounts in the Canary and Madeira volcanic provinces: Support for the mantle plume hypothesis: Earth and Planetary Science Letters, v. 237, no. 1-2, p. 85-101, doi: 10.1016/j.eps1.2005.04.037.

Geng, M., Farquharson, C., Welford, J.K., and Peace, A.L., 2019, 3-D inversion of airborne gravity gradiometry data for the Budgell Harbour Stock, Newfoundland: A case history using a probabilistic approach: Geophysics,.

Geoffroy, L., 2005, Volcanic passive margins: Comptes Rendus - Geoscience, v. 337, no. 16, p. 1395-1408, doi: 10.1016/j.crte.2005.10.006.

Geoffroy, L., Burov, E.B., and Werner, P., 2015, Volcanic passive margins: another way to break up continents: Scientific Reports, v. 5, p. 14828, doi: 10.1038/srep14828.

Gernigon, L., Blischke, A., Nasuti, A., and Sand, M., 2015, Conjugate volcanic rifted margins, seafloor spreading, and microcontinent: Insights from new high-resolution aeromagnetic surveys in the Norway Basin: Tectonics, , no. July, p. 907-933, doi: 10.1002/2014TC003717.

Gernigon, L., Franke, D., Geoffroy, L., Schiffer, C., Foulger, G.R., and Stoker, M., 2019, Crustal fragmentation, magmatism, and the diachronous opening of the NorwegianGreenland Sea: Earth-Science Reviews,.

Gion, A., Williams, S., and Muller, D., 2017, A reconstruction of the Eurekan Orogeny incorporating deformation constraints: Tectonics, p. 304-320, doi: 10.1002/2015TC004094.

Gouiza, M., Hall, J., and Bertotti, G., 2015, Rifting and pre-rift lithosphere variability in the Orphan Basin, Newfoundland margin, Eastern Canada: Basin Research, v. 27, no. 4, p. 367-386, doi: 10.1111/bre.12078.

Gouiza, M., Hall, J., and Welford, J.K., 2016, Tectono-stratigraphic evolution and crustal 
architecture of the Orphan Basin during North Atlantic rifting: International Journal of Earth Sciences, doi: 10.1007/s00531-016-1341-0.

1239

1240

1241

1242

1243

1244

1245

1246

1247

1248

1249

1250

1251

1252

1253

1254

1255

1256

1257

1258

1259

1260

1261

1262

1263

1264

1265

1266

1267

1268

1269

1270

1271

1272

1273

1274

1275

1276

Gouiza, M., and Paton, D.A., 2019, The role of inherited lithospheric heterogeneities in defining the crustal architecture of rifted margins and the magmatic budget during continental breakup.: Geochemistry, Geophysics, Geosystems,.

Grant, A.C., 1987, Inversion tectonics on the continental margin east of Newfoundland: Geology, v. 15, no. 9, p. 845-848.

Grocott, J., and McCaffrey, K., 2017, Basin Evolution and Destruction in an Early Proterozoic Continental Margin: the Rinkian Fold-Thrust Belt of Central West Greenland: Journal of the Geological Society, doi: 10.1144/jgs2016-109.

Gurnis, M., Turner, M., Zahirovic, S., DiCaprio, L., Spasojevic, S., M??ller, R.D., Boyden, J., Seton, M., Manea, V.C., and Bower, D.J., 2012, Plate tectonic reconstructions with continuously closing plates: Computers and Geosciences, v. 38, no. 1, p. 35-42, doi: 10.1016/j.cageo.2011.04.014.

Gurnis, M., Yang, T., Cannon, J., Turner, M., Williams, S., Flament, N., and Müller, R.D., 2018, Global tectonic reconstructions with continuously deforming and evolving rigid plates: Computers and Geosciences, v. 116, p. 32-41, doi: 10.1016/j.cageo.2018.04.007.

Hansen, J., Jerram, D.A., McCaffrey, K., and Passey, S.R., 2009, The onset of the North Atlantic Igneous Province in a rifting perspective: Geological Magazine, v. 146, no. 03, p. 309, doi: 10.1017/S0016756809006347.

Hardy, R.J.J., Querendez, E., Biancotto, F., Jones, S.M., O’Sullivan, J., and White, N., 2010, New methods of improving seismic data to aid understanding of passive margin evolution: a series of case histories from offshore west of Ireland: Petroleum Geology: From Mature Basins to New Frontiers-Proceedings of the 7th Petroleum Geology Conference, v. 7, p. 1005-1012, doi: 10.1144/0071005.

Hitchen, K., 2004, The geology of the UK Hatton-Rockall margin: Marine and Petroleum Geology, v. 21, no. 8, p. 993-1012, doi: 10.1016/j.marpetgeo.2004.05.004.

Hopper, J.R., Dahl-Jensen, T., Holbrook, W.S., Larsen, H.C., Lizarralde, D., Korenaga, J., Kent, G.M., and Kelemen, P.B., 2003, Structure of the SE Greenland margin from seismic reflection and refraction data: Implications for nascent spreading center subsidence and asymmetric crustal accretion during North Atlantic opening: Journal of Geophysical Research, v. 108, doi: 10.1029/2002jb001996.

Hosseinpour, M., Müller, R.D., Williams, S.E., and Whittaker, J.M., 2013, Full-fit reconstruction of the Labrador Sea and Baffin Bay: Solid Earth, v. 4, no. 2, p. 461-479, doi: $10.5194 / \mathrm{se}-4-461-2013$.

Japsen, P., Bonow, J.M., Peulvast, J.-P., and Wilson, R.W., 2006, Uplift, erosion and fault reactivation in southern West Greenland.: GEUS Field Reports, v. 63.

Jauer, C.D., Oakey, G.N., Williams, G., and Wielens, J.B.W.H., 2014, Saglek Basin in the Labrador Sea, east coast Canada; stratigraphy, structure and petroleum systems: Bulletin of Canadian Petroleum Geology, v. 62, no. 4. 
Jones, S.M., White, N., and Lovell, B., 2001, Cenozoic and Cretaceous transient uplift in the Porcupine Basin and its relationship to a mantle plume: Geological Society, London, Special Publications, v. 188, no. 1, p. 345-360, doi: 10.1144/GSL.SP.2001.188.01.20.

Joppen, M., and White, R.S., 1990, The structure and subsidence of Rockall Trough from two-ship seismic experiments: Journal of Geophysical Research, v. 95, no. B12, p. 19821, doi: 10.1029/JB095iB12p19821.

Keen, C.E., Dafoe, L.T., and Dickie, K., 2014, A volcanic province near the Western termination of the Charlie-Gibbs Fracture Zone at the rifted margin, offshore northeast Newfoundland: Tectonics, v. 33, no. 6, p. 1133-1153, doi: 10.1002/2014TC003547.

Kerr, A., Ryan, B., Gower, C.F., and Wardle, R.J., 1996, The Makkovik Province: extension of the Ketilidian Mobile Belt in mainland North America: Geological Society, London, Special Publications, v. 112, no. 1, p. 155-177, doi: 10.1144/GSL.SP.1996.112.01.09.

Koopmann, H., Brune, S., Franke, D., and Breuer, S., 2014, Linking rift propagation barriers to excess magmatism at volcanic rifted margins: Geology, v. 42, no. 12, p. 1071-1074, doi: $10.1130 / \mathrm{G} 36085.1$.

Lapointe, P.L., 1979, Paleomagnetism of the Notre Dame Bay lamprophyre dikes, Newfoundland, and the opening of the North Atlantic Ocean: Canadian Journal of Earth Sciences, v. 16, no. 9, p. 1823-1831.

Larsen, L.M., Heaman, L.M., Creaser, R.A., Duncan, R.A., Frei, R., and Hutchison, M., 2009, Tectonomagmatic events during stretching and basin formation in the Labrador Sea and the Davis Strait: evidence from age and composition of Mesozoic to Palaeogene dyke swarms in West Greenland: Journal of the Geological Society, v. 166, no. 6, p. 999-1012, doi: 10.1144/0016-76492009-038.

Lau, K.W.H., Louden, K.E., Funck, T., Tucholke, B.E., Holbrook, W.S., Hopper, J.R., and Christian Larsen, H., 2006, Crustal structure across the Grand Banks-Newfoundland Basin Continental Margin - II. Results from a seismic reflection profile K.W.: Geophysical Journal International, v. 167, no. 1, p. 127-156, doi: 10.1111/j.1365246X.2006.02988.x.

Lau, K.W.H., Watremez, L., Louden, K.E., and Nedimovíć, M.R., 2015, Structure of thinned continental crust across the Orphan Basin from a dense wide-angle seismic profile and gravity data: Geophysical Journal International, v. 202, no. 3, p. 1969-1992, doi: $10.1093 / \mathrm{gji} / \mathrm{ggv} 261$.

Leleu, S., Hartley, A.J., van Oosterhout, C., Kennan, L., Ruckwied, K., and Gerdes, K., 2016, Structural, stratigraphic and sedimentological characterisation of a wide rift system: the Triassic rift system of the Central Atlantic Domain: Earth-Science Reviews, v. 158, p. 89-124.

Li, Y., and Oldenburg, D., 1998, 3-D inversion of gravity data: Geophysics, v. 63, no. 1, p. 109-119, doi: 10.1190/1.1444302.

Li, Y., and Oldenburg, D., 1996, 3-D inversion of magnetic data: Geophysics, v. 61, no. 2, p. 394-408, doi: 10.1190/1.1443968.

Lister, G.S., Etheridge, M.A., and Symonds, P.A., 1986, Detachment Faulting and the 
Louden, K., Wu, Y., and Tari, G., 2013, Systematic variations in basement morphology and rifting geometry along the Nova Scotia and Morocco conjugate margins: Geological Society, London, Special Publications, v. 369, p. 267-287, doi: 10.1144/SP369.9.

Lundin, E., 2002, North Atlantic - Arctic : Overview of sea-floor spreading and rifting history, in Mid Norway plate reconstructions atlas with global and Atlantic perspectives, p. 41-75.

Lundin, E.R., and Doré, A.G., 2011, Hyperextension, serpentinization, and weakening: A new paradigm for rifted margin compressional deformation: Geology, v. 39, no. 4, p. 347-350, doi: 10.1130/G31499.1.

Lundin, E.R., Doré, A.G., and Redfield, T.F., 2018, Magmatism and extension rates at rifted margins: Petroleum Geoscience, p. 32-33.

Magee, C., Jackson, C.A.L., and Schofield, N., 2014, Diachronous sub-volcanic intrusion along deep-water margins: Insights from the Irish Rockall Basin: Basin Research, v. 26, no. 1 , p. $85-105$, doi: $10.1111 /$ bre. 12044 .

Marillier, F., Hall, J., Hughes, S., Louden, K., Reid, I., Roberts, B., Clowes, R., Coté, T., Fowler, J., Guest, S., Lu, H., Luetgert, J., Quinlan, G., Spencer, C., et al., 1994, LITHOPROBE East onshore-offshore seismic refraction survey -constraints on interpretation of reflection data in the Newfoundland Appalachians: Tectonophysics, v. 232, no. 1-4, p. 43-58, doi: 10.1016/0040-1951(94)90075-2.

Matthews, K.J., Maloney, K.T., Zahirovic, S., Williams, S.E., Seton, M., and Müller, R.D., 2016, Global plate boundary evolution and kinematics since the late Paleozoic: Global and Planetary Change, v. 146, p. 226-250, doi: 10.1016/j.gloplacha.2016.10.002.

McDonnell, A., and Shannon, P.M., 2001, Comparative Tertiary stratigraphic evolution of the Porcupine and Rockall basins: Geological Society, London, Special Publications, v. 188, no. 1, p. 323-344, doi: 10.1144/GSL.SP.2001.188.01.19.

McKenzie, D., 1978, Some remarks on the development of sedimentary basins: Earth and

Müller, R.D., Cannon, J., Qin, X., and Watson, R.J., 2018, GPlates - Building a Virtual Earth Planetary Science Letters, v. 40, no. 1, p. 25-32, doi: 10.1016/0012-821X(78)90071-7. Through Deep Time: Geochemistry Geophysics Geosystems, doi: 10.1029/2018GC007584.

Müller, R.D., Seton, M., Zahirovic, S., Williams, S.E., Matthews, K.J., Wright, N.M., Shephard, G.E., Maloney, K.T., Barnett-Moore, N., Hosseinpour, M., Bower, D.J., and Cannon, J., 2016, Ocean Basin Evolution and Global-Scale Plate Reorganization Events Since Pangea Breakup: Annual Review of Earth and Planetary Sciences, v. 44, no. 1, p. 107-138, doi: 10.1146/annurev-earth-060115-012211. Heine, C., Le Breton, E., Liu, S., Russell, S.H.J., Yang, T., Leonard, J., and Gurnis, M., 2019, A global plate model including lithospheric deformation along major rifts and orogens since the Triassic: Tectonics, doi: 10.1029/2018TC005462. 
Naylor, D., and Shannon, P.M., 2005, The structural framework of the Irish Atlantic Margin, in Petroleum Geology: North-West Europe and Global Perspectives-Proceedings of the 6th Petroleum Geology Conference, p. 1009-1021.

Nielsen, T.K., 2002, Formation of volcanic rifted margins: Are temperature anomalies required? Geophysical Research Letters, v. 29, no. 21, p. 2022, doi: 10.1029/2002GL015681.

Nirrengarten, M., Manatschal, G., Tugend, J., Kusznir, N., and Sauter, D., 2018, Kinematic evolution of the southern North Atlantic: implications for the formation of hyperextended rift systems: Tectonics, p. 2, doi: 10.1002/2017TC004495.

O’Reilly, B.M., Hauser, F., Ravaut, C., Shannon, P.M., and Readman, P.W., 2006, Crustal thinning, mantle exhumation and serpentinization in the Porcupine Basin, offshore Ireland: evidence from wide-angle seismic data: Journal of the Geological Society, v. 163, no. 5, p. 775-787, doi: 10.1144/0016-76492005-079.

Oakey, G.N., and Chalmers, J. a, 2012, A new model for the Paleogene motion of Greenland relative to North America : Plate reconstructions of the Davis Strait and Nares Strait regions between Canada and Greenland: Journal of Geophysical Research: Solid Earth, v. 117, no. B10, p. 1-28, doi: 10.1029/2011JB008942.

Pe-Piper, G., Jansa, L.F., and Lambert, R.S.J., 1992, Early Mesozoic magmatism on the eastern Canadian margin: Petrogenetic and tectonic significance: Geological Society of America Special Paper, v. 268, no. 2.

Pe-Piper, G., Meredyk, S., Zhang, Y., Piper, D.J.W., and Edinger, E., 2013, Petrology and tectonic significance of seamounts within transitional crust east of Orphan Knoll, offshore eastern Canada: Geo-Marine Letters, v. 33, no. 6, p. 433-447, doi: 10.1007/s00367-013-0342-2.

Pe-Piper, G., Piper, D.J.W., Jansa, L.F., and de Jonge, A., 2007, Early Cretaceous opening of the North Atlantic Ocean: Implications of the petrology and tectonic setting of the Fogo seamounts off the SW Grand Banks, Newfoundland: Bulletin of the Geological Society of America, v. 119, no. 5-6, p. 712-724, doi: 10.1130/B26008.1.

Peace, A.L., Dempsey, E.D., Schiffer, C., Welford, J.K., and Ken, J.W., 2018a, Evidence for basement reactivation during the opening of the Labrador Sea from the Makkovik Province, Labrador, Canada: Insights from field-data and numerical models: Geosciences,.

Peace, A.L.L., Dempsey, E.D.D., Schiffer, C., Welford, J.K., Ken, J.W., McCaffrey, K., Imber, J., and Phethean, J., 2018b, Evidence for Basement Reactivation during the Opening of the Labrador Sea from the Makkovik Province, Labrador, Canada: Insights from Field Data and Numerical Models: Geosciences, v. 8, no. 8, p. 308, doi: $10.3390 /$ geosciences 8080308 .

Peace, A.L., Foulger, G.R., Schiffer, C., and Mccaffrey, K.J.W., 2017a, Evolution of Labrador Sea-Baffin Bay: Plate or Plume Processes? Geoscience Canada, v. 44, no. 3, doi: 10.12789/geocanj.2017.44.120.

Peace, A.L., McCaffrey, K.J.W., Imber, J., Hobbs, R., van Hunen, J., and Gerdes, K., 2017b, Quantifying the influence of sill intrusion on the thermal evolution of organic-rich 
sedimentary rocks in nonvolcanic passive margins: An example from ODP 210-1276, offshore Newfoundland, Canada: Basin Research, v. 29, no. 3, p. 249-265, doi: $10.1111 /$ bre.12131.

Peace, A., McCaffrey, K.J.W., Imber, J., van Hunen, J., Hobbs, R., and Wilson, R., 2018c, The role of pre-existing structures during rifting, continental breakup and transform system development, offshore West Greenland: Basin Research, v. 30, no. 3, p. $373-$ 394, doi: 10.1111/bre.12257.

Peace, A., McCaffrey, K.J.W., Imber, J., Phethean, J., Nowell, G., Gerdes, K., and Dempsey, E., 2016, An evaluation of Mesozoic rift-related magmatism on the margins of the Labrador Sea: Implications for rifting and passive margin asymmetry: Geosphere, v. 12, no. 6, doi: 10.1130/GES01341.1.

Peace, A.L., Welford, J.K., Geng, M., Sandeman, H., Gaetz, B.D., and Ryan, S.S., 2018d, Rift-related magmatism on magma-poor margins: Structural and potential-field analyses of the Mesozoic Notre Dame Bay intrusions, Newfoundland, Canada and their link to North Atlantic Opening: Tectonophysics, v. 745, no. October, p. 24-45, doi: 10.1016/j.tecto.2018.07.025.

Peron-Pinvidic, G., Gernigon, L., Gaina, C., and Ball, P., 2012a, Insights from the Jan Mayen system in the Norwegian-Greenland sea-I. Mapping of a microcontinent: Geophysical Journal International, v. 191, no. 2, p. 385-412, doi: 10.1111/j.1365246X.2012.05639.x.

Peron-Pinvidic, G., Gernigon, L., Gaina, C., and Ball, P., 2012b, Insights from the Jan Mayen system in the Norwegian-Greenland Sea-II. Architecture of a microcontinent: Geophysical Journal International, v. 191, no. 2, p. 413-435, doi: 10.1111/j.1365246X.2012.05623.x.

Peron-Pinvidic, G., and Manatschal, G., 2010, From microcontinents to extensional allochthons: witnesses of how continents rift and break apart? Petroleum Geoscience, v. 16, no. 3, p. 189-197, doi: 10.1144/1354-079309-903.

Peron-Pinvidic, G., Manatschal, G., Minshull, T.A., and Sawyer, D.S., 2007, Tectonosedimentary evolution of the deep Iberia-Newfoundland margins: Evidence for a complex breakup history: Tectonics, v. 26, no. 2, p. TC2011, doi: 10.1029/2006TC001970.

Petersen, K.D., Schiffer, C., and Nagel, T.J., 2018, LIP formation and protracted lower mantle upwelling induced by rifting and delamination: Scientific Reports, p. 1-11, doi: 10.1038/s41598-018-34194-0.

Phethean, J., Kalnins, L., van Hunen, J., Biffi, P.G., Davies, R.J., and McCaffrey, K.J.W., 2016, Madagascar's escape from Africa: A high-resolution plate reconstruction for the Western Somali Basin and implications for supercontinent dispersal: Geochemistry, Geophysics, Geosystems, v. 17, no. 7, p. 2825-2834, doi: 10.1002/2016GC006406.

Picazo, S., Müntener, O., Manatschal, G., Bauville, A., Karner, G., and Johnson, C., 2016, Mapping the nature of mantle domains in Western and Central Europe based on clinopyroxene and spinel chemistry: Evidence for mantle modification during an extensional cycle: Lithos, v. 266-267, no. September 2016, p. 233-263, doi: 10.1016/j.lithos.2016.08.029. 
1443

1444

1445

1446

1447

1448

1449

1450

1451

1452

1453

1454

1455

1456

1457

1458

1459

1460

1461

1462

1463

1464

1465

1466

1467

1468

1469

1470

1471

1472

1473

1474

1475

1476

1477

1478

1479

1480

1481

1482

1483
Polteau, S., Mazzini, A., Hansen, G., Planke, S., Jerram, D.A., Millett, J., and Abdelmalak, M.M., 2018, The pre-breakup stratigraphy and petroleum system of the Southern Jan Mayen Ridge revealed by seafloor sampling: Tectonophysics, doi: 10.1016/j.tecto.2018.04.016.

Prada, M., Lavoué, F., Saqab, M.M., Reilly, B.M.O., Lebedev, S., Walsh, J.J., and Childs, C., 2018, Across - axis variations in petrophysical properties of the North Porcupine Basin , offshore Ireland: New insights from long - streamer traveltime tomography: , no. June, p. 1-18, doi: $10.1111 /$ bre.12308.

Rattey, R.P., and Hayward, A.B., 1993, Sequence stratigraphy of a failed rift system: the Middle Jurassic to Early Cretaceous basin evolution of the Central and Northern North Sea: Petroleum Geology of Northwest Europe: Proceedings of the 4th Conference on Petroleum Geology of NW. Europe, at the Barbican Centre, London, v. 1, p. 215-249, doi: 10.1144/0040215.

Reston, T.J., 2009, The structure, evolution and symmetry of the magma-poor rifted margins of the North and Central Atlantic: A synthesis: Tectonophysics, v. 468, no. 1-4, p. 6-27, doi: 10.1016/j.tecto.2008.09.002.

Reston, T.J., Gaw, V., Pennell, J., Klaeschen, D., Stubenrauch, A., and Walker, I., 2004, Extreme crustal thinning in the south Porcupine Basin and the nature of the Porcupine Median High: implications for the formation of non-volcanic rifted margins: Journal of the Geological Society, v. 161, no. 5, p. 783-798, doi: 10.1144/0016-764903-036.

Reston, T.J., Pennell, J., Stubenrauch, A., Walker, I., and Perez-Gussinye, M., 2001, Detachment faulting, mantle serpentinization, and serpentinite-mud, volcanism beneath the Porcupine Basin, southwest of Ireland: Geology, v. 29, no. 7, p. 587-590, doi: 10.1130/0091-7613(2001)029<0587:DFMSAS>2.0.CO;2.

Roberts, A.M., Alvey, A.D., and Kusznir, N.J., 2018, Crustal structure and heat-flow history in the UK Rockall Basin, derived from backstripping and gravity-inversion analysis: Petroleum Geoscience,

Rowley, D.B., and Lottes, A.L., 1988, Plate-kinematic reconstructions of the North Atlantic and Arctic: Late Jurassic to present: Tectonophysics, v. 155, no. 1-4, p. 73-120.

Schiffer, C., Peace, A., Phethean, J., Gernigon, L., McCaffrey, K.J.W., Petersen, K.D., and Foulger, G.R., 2018, The Jan Mayen Microplate Complex and the Wilson Cycle: in Tectonic Evolution: 50 Years of the Wilson Cycle Concept: Geological Society of London, Special Publications, v. 470, doi: 10.1144/SP470.2.

Schofield, N., Jolley, D., Holford, S., Archer, S., Watson, D., Hartley, A., Howell, J., Muirhead, D., Underhill, J., and Green, P., 2018, Challenges of future exploration within the UK Rockall Basin: Petroleum geology of Northwest Europe: 50 years of learning. Proceedings of the 8th Petroleum Geology Conference, p. 1-19, doi: 10.1144/PGC8.37.

Scotchman, I.C., Doré, A.G., and Spencer, A.M., 2018, Petroleum systems and results of exploration on the Atlantic margins of the UK, Faroes and Ireland: what have we learnt? Petroleum geology of Northwest Europe: 50 years of learning. Proceedings of the 8 th Petroleum Geology Conference, p. 11pp, doi: 10.1144/PGC8.14.

Seton, M., Müller, R.D., Zahirovic, S., Gaina, C., Torsvik, T., Shephard, G., Talsma, A., 
Gurnis, M., Turner, M., Maus, S., and Chandler, M., 2012, Global continental and ocean basin reconstructions since 200Ma: Earth-Science Reviews, v. 113, no. 3-4, p. 212-270, doi: 10.1016/j.earscirev.2012.03.002.

Shannon, P., 2018, Old challenges, new developments and new plays in Irish offshore exploration: Petroleum Geology of Northwest Europe: 50 Years of Learning Proceedings of the 8th Petroleum Geology Conference, p. 171-185, doi: 10.1144/PGC8.12.

Shannon, P.M., 1991, The development of Irish offshore sedimentary basins: Journal of the Geological Society, v. 148, no. 1, p. 181-189, doi: 10.1144/gsjgs.148.1.0181.

Shannon, P.M., Jacob, A.W.B., O'Reilly, B.M., Hauser, F., Readman, P.W., and Makris, J., 1999, Structural setting, geological development and basin modelling in the Rockall Trough: Petroleum Geology of Northwest Europe: Proceedings of the 5th Conference on the Petroleum Geology of Northwest Europe, p. 421-431, doi: 10.1144/0050421.

Shorttle, O., Maclennan, J., and Lambart, S., 2014, Quantifying lithological variability in the mantle: Earth and Planetary Science Letters, v. 395, p. 24-40, doi: 10.1016/j.epsl.2014.03.040.

Sibuet, J.-C., Srivastava, S.P., Enachescu, M., and Karner, G.D., 2007, Early Cretaceous motion of Flemish Cap with respect to North America: implications on the formation of Orphan Basin and SE Flemish Cap Galicia Bank conjugate margins: Geological Society, London, Special Publications, v. 282, no. 1, p. 63-76, doi: 10.1144/SP282.4.

Sinclair, I.K., 1995, Sequence stratigraphic response to Aptian-Albian rifting in conjugate margin basins: a comparison of the Jeanne d'Arc Basin, offshore Newfoundland, and the Porcupine Basin, offshore Ireland: Geological Society, London, Special Publications, v. 90, no. 1, p. 29-49.

Sinclair, I.K., Shannon, P.M., Williams, B.P.J., Harker, S.D., and Mooren, J.G., 1994, Tectonic control on sedimentary evolution of three North Atlantic borderland Mesozoic basins1: Basin Research, v. 6, no. 4, p. 193-217, doi: 10.1111/j.13652117.1994.tb00085.x.

Skogseid, J., 2010, The Orphan Basin - a key to understanding the kinematic linkage between North and NE Atlantic Mesozoic rifting: II Central and North Atlantic Conjugate Margins Conference, v. II, p. 13-23.

Smith, W.H., and Sandwell, D., 1997, Global Sea Floor Topography from Satellite Altimetry and Ship Depth Soundings: Science, v. 277, no. 5334, p. 1956-1962, doi: 10.1126/science.277.5334.1956.

Srivastava, S.P., 1978, Evolution of the Labrador Sea and its bearing on the early evolution of the North Atlantic: Geophysical Journal International, v. 52, no. 2, p. 313-357, doi: 10.1111/j.1365-246X.1978.tb04235.x.

Srivastava, S.P., and Roest, W.R., 1999, Extent of oceanic crust in the Labrador Sea: Marine and Petroleum Geology, v. 16, no. 1, p. 65-84, doi: 10.1016/S0264-8172(98)00041-5.

St-Onge, M.R., Van Gool, J.A.M., Garde, A.A., Scott, D.J., Gool, J.A.M. Van, Garde, A.A., Scott, D.J., Van Gool, J.A.M., Garde, A.A., and Scott, D.J., 2009, Correlation of 
Archaean and Palaeoproterozoic units between northeastern Canada and western Greenland: constraining the pre-collisional upper plate accretionary history of the TransHudson orogen: Geological Society, London, Special Publications, v. 318, no. 1, p. 193235, doi: $10.1144 / \mathrm{sp} 318.7$.

Stoker, M.S., Stewart, M.A., Shannon, P.M., Bjerager, M., and Nielsen, T., 2016, An overview of the Upper Palaeozoic - Mesozoic stratigraphy of the NE Atlantic region: The NE Atlantic Region: A Reappraisal of Crustal Structure, Tectonostratigraphy and Magmatic Evolution, v. 447, p. 11-68, doi: 10.1144/SP447.2.

Štolfová, K., and Shannon, P.M., 2009, Permo-Triassic development from Ireland to Norway: basin architecture and regional controls: Geological Journal, v. 44, no. 6, p. 652-676.

Strong, D.F., and Harris, A., 1974, The Petrology of Mesozoic Alkaline Intrusives of Central Newfoundland: Canadian Journal of Earth Sciences, v. 11, p. 1208-1219, doi: 10.1139/e74-114.

Suckro, S.K.S.K., Gohl, K., Funck, T., Heyde, I., Schreckenberger, B., Gerlings, J., and Damm, V., 2013, The Davis Strait crust-a transform margin between two oceanic basins: Geophysical Journal International, v. 193, no. 1, p. 78-97, doi: $10.1093 / \mathrm{gji} / \mathrm{ggs} 126$.

Tankard, A.J., and Welsink, H.J., 1987, Extensional tectonics and stratigraphy of Hibernia oil field, Grand Banks, Newfoundland: AAPG Bulletin, v. 71, no. 10, p. 1210-1232.

Tate, M.P., 1993, Structural framework and tectono-stratigraphic evolution of the Porcupine Seabight Basin, offshore Western Ireland: Marine and Petroleum Geology, v. 10, no. 2, p. 95-123, doi: 10.1016/0264-8172(93)90016-L.

Tate, M.P., and Dobson, M.R., 1988, Syn- and post-rift igneous activity in the Porcupine Seabight Basin and adjacent continental margin W of Ireland: Geological Society, London, Special Publications, v. 39, no. 1, p. 309 LP-334.

Tate, M.P., Dodd, C.D., and Grant, N.T., 1999, The northeast Rockall basin and its significance in the evolution of the Rockall-Faeroes/East Greenland rift system: Petroleum Geology of Northwest Europe: Proceedings of the 5th Conference on the Petroleum Geology of Northwest Europe, v. 1, no. c, p. 391-406, doi: 10.1144/0050391.

Tavani, S., Bertok, C., Granado, P., Piana, F., Salas, R., Vigna, B., and Muņoz, J.A., 2018, The Iberia-Eurasia plate boundary east of the Pyrenees: Earth-Science Reviews,.

Thomson, K., 2005, Extrusive and intrusive magmatism in the North Rockall Trough: Petroleum Geology Conference series, v. 6, p. 1621-1630, doi: 10.1144/0061621.

Tucholke, B.E., Sawyer, D.S., and Sibuet, J.-C., 2007, Breakup of the Newfoundland Iberia rift: Geological Society, London, Special Publications, v. 282, no. 1, p. 9-46, doi: 10.1144/SP282.2.

Tucholke, B.E., and Sibuet, J., 2007, Leg 210 synthesis: tectonic, magmatic, and sedimentary evolution of the Newfoundland-Iberia rift: Proceedings of the Ocean Drilling Program, Scientific Results Volume 210, v. 210, p. 1-56, doi: 10.2973/odp.proc.sr.210.101.2007.

Umpleby, D.C., 1979, Geology of the Labrador Shelf: Geological Survey of Canada, v. 79- 
Vissers, R.L.M., and Meijer, P.T., 2012a, Iberian plate kinematics and Alpine collision in the Pyrenees: Earth-Science Reviews, v. 114, no. 1-2, p. 61-83, doi: 10.1016/j.earscirev.2012.05.001.

Vissers, R.L.M., and Meijer, P.T., 2012b, Mesozoic rotation of Iberia: Subduction in the Pyrenees? Earth-Science Reviews, v. 110, no. 1-4, p. 93-110, doi: 10.1016/j.earscirev.2011.11.001.

Watremez, L., Helen Lau, K.W., Nedimović, M.R., and Louden, K.E., 2015, Traveltime tomography of a dense wide-angle profile across Orphan Basin: Geophysics, v. 80, no. 3, p. B69-B82, doi: 10.1190/geo2014-0377.1.

Watremez, L., Prada, M., Minshull, T., O’Reilly, B., Chen, C., Reston, T., Shannon, P., Wagner, G., Gaw, V., Klaeschen, D., Edwards, R., and Lebedev, S., 2018, Deep structure of the Porcupine Basin from wide-angle seismic data: Geological Society, London, Petroleum Geology Conference series, v. 8, p. PGC8.26, doi: 10.1144/PGC8.26.

Welford, J.K., Hall, J., Sibuet, J.C., and Srivastava, S.P., 2010, Structure across the northeastern margin of Flemish Cap, offshore Newfoundland from Erable multichannel seismic reflection profiles: Evidence for a transtensional rifting environment: Geophysical Journal International, v. 183, no. 2, p. 572-586, doi: 10.1111/j.1365246X.2010.04779.x.

Welford, J.K., Peace, A.L., Geng, M., Dehler, S.A., and Dickie, K., 2018, Crustal structure of Baffin Bay from constrained three-dimensional gravity inversion and deformable plate tectonic models: Geophysical Journal International, doi: 10.1093/gji/ggy193.

Welford, J.K., Shannon, P.M., O’Reilly, B.M., Hall, J., Reilly, B.M.O., and Hall, J., 2012, Comparison of lithosphere structure across the Orphan Basin - Flemish Cap and Irish Atlantic conjugate continental margins from constrained 3D gravity inversions: Journal of the Geological Society, v. 169, no. 4, p. 405-420, doi: 10.1144/0016-76492011114.Comparison.

White, R.S., 1992, Magmatism during and after continental break-up: Geological Society, London, Special Publications, v. 68, no. 1, p. 1-16, doi: 10.1144/GSL.SP.1992.068.01.01.

White, R., and McKenzie, D., 1989, Magmatism at rift zones: The generation of volcanic continental margins and flood basalts: Journal of Geophysical Research, v. 94, no. B6, p. 7685, doi: 10.1029/JB094iB06p07685.

White, N., Tate, M., and Conroy, J.-J., 1992, Lithospheric stretching in the Porcupine Basin, west of Ireland: Geological Society, London, Special Publications, v. 62, no. 1, p. 327 LP-331.

Whittaker, R.C., 2016, A New Deformable Plate Reconstruction of the Irish - Newfoundland Conjugate Margin: , no. June 2012, p. 1-4.

Wilkinson, C.M., Ganerød, M., Hendriks, B.W.H., and Eide, E.A., 2016, Compilation and appraisal of geochronological data from the North Atlantic Igneous Province ( NAIP ): 

Geological Society Special Publications,.

Williams, S., Flament, N., Heine, C., Vazifehshenas, M.H., Seton, M., and Gurnis, M., 2012a, Geodynamic modeling of passive margin systems from tectonic reconstructions with deforming plate boundaries: Geophys. Res. Abstracts, v. 14, p. 6830.

Williams, S.E., Müller, R.D., Landgrebe, T.C.W., and Whittaker, J.M., 2012b, An opensource software environment for visualizing and refining plate tectonic reconstructions using high-resolution geological and geophysical data sets: GSA Today, v. 22, no. 4-5, p. 4-9, doi: 10.1130/GSATG139A.1.THE.

Wilson, R.W., Klint, K.E.S., Van Gool, J.A.M., McCaffrey, K.J.W., Holdsworth, R.E., and Chalmers, J.A., 2006, Faults and fractures in central West Greenland: onshore expression of continental break-up and sea-floor spreading in the Labrador-Baffin Bay Sea: Geological Survey Of Denmark And Greenland Bulletin, v. 11, p. 185-204. Atlantic margin, during the Late Jurassic-Early Cretaceous, implication for a regional compressional event: Marine and Petroleum Geology, v. 36, no. 1, p. 140-153, doi: 10.1016/j.marpetgeo.2012.05.003. 

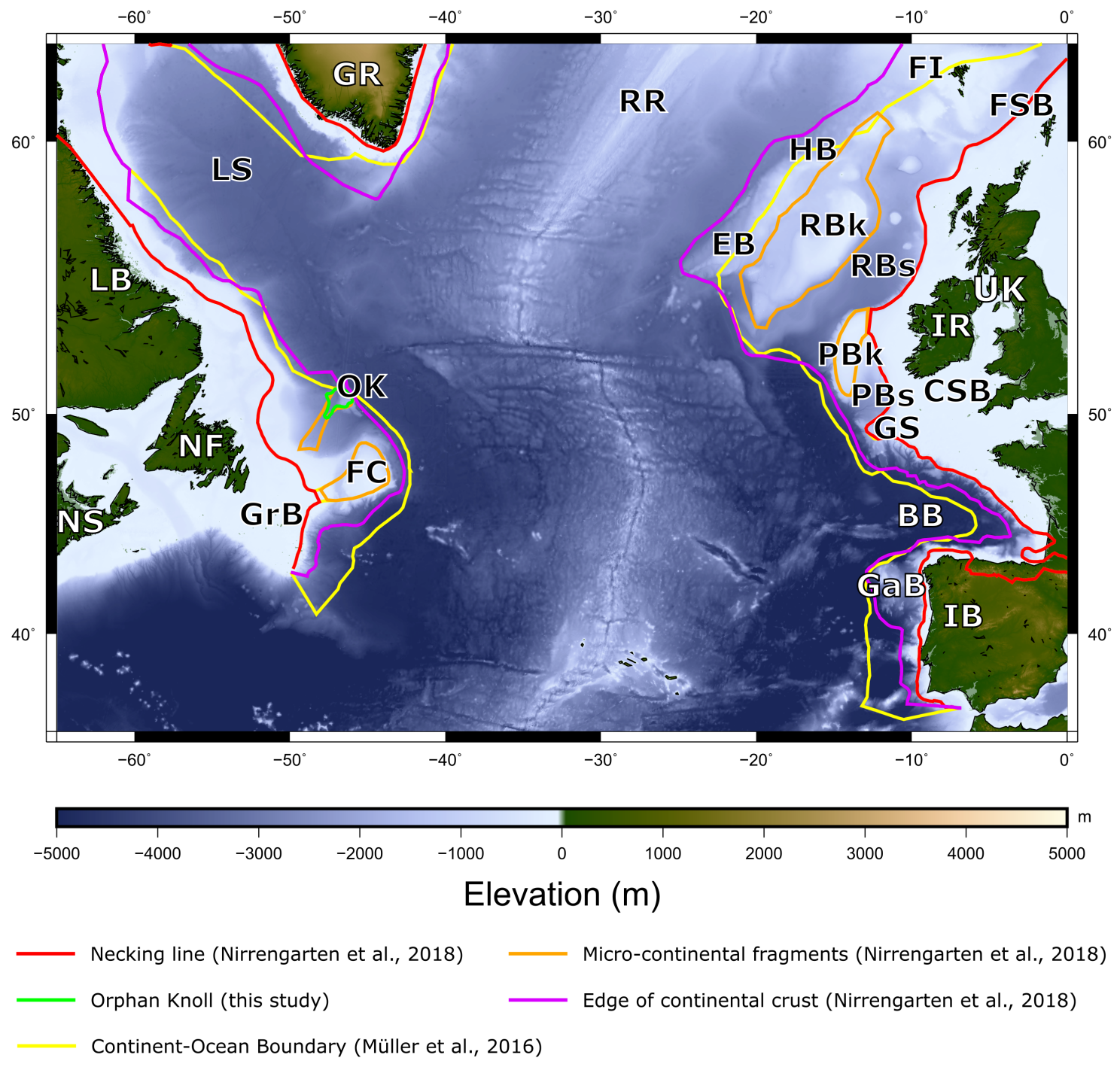

1629 Overview of the southern North Atlantic study area and the main inputs for the GPlates models. 1630 The Müller et al. (2016) COB has been cropped to just the segments used in the deformable 1631 models. Elevation data from Smith and Sandwell V18.1 (Smith and Sandwell, 1997). AGFZ = 1632 Azores-Gibraltar Fracture Zone, BB = Bay of Biscay, CGFZ = Charlie-Gibbs Fracture Zone, $1633 \mathrm{CSB}=$ Celtic Sea Basin, EB $=$ Edoras Bank, FC = Flemish Cap, FI = Faroe Islands, FSB = 1634 Faroe-Shetland Basin, $\mathrm{GaB}=$ Galicia Bank, $\mathrm{GrB}=$ Grand Banks, GR = Greenland, GS = Goban 1635 Spur, HB = Hatton Bank, IB = Iberia, IR = Ireland, LB = Labrador, $L S=$ Labrador Sea, MAR $1636=$ Mid-Atlantic Ridge, $\mathrm{NF}=$ Newfoundland, NS $=$ Nova Scotia, OB $=$ Orphan Basin, OK = 1637 Orphan Knoll, PBk = Porcupine Bank, PBs = Porcupine Basin, QB = Quebec, RBk = Rockall 1638 Bank, RBs = Rockall Basin, RR $=$ Reykjanes Ridge, $\mathrm{UK}=$ United Kingdom 

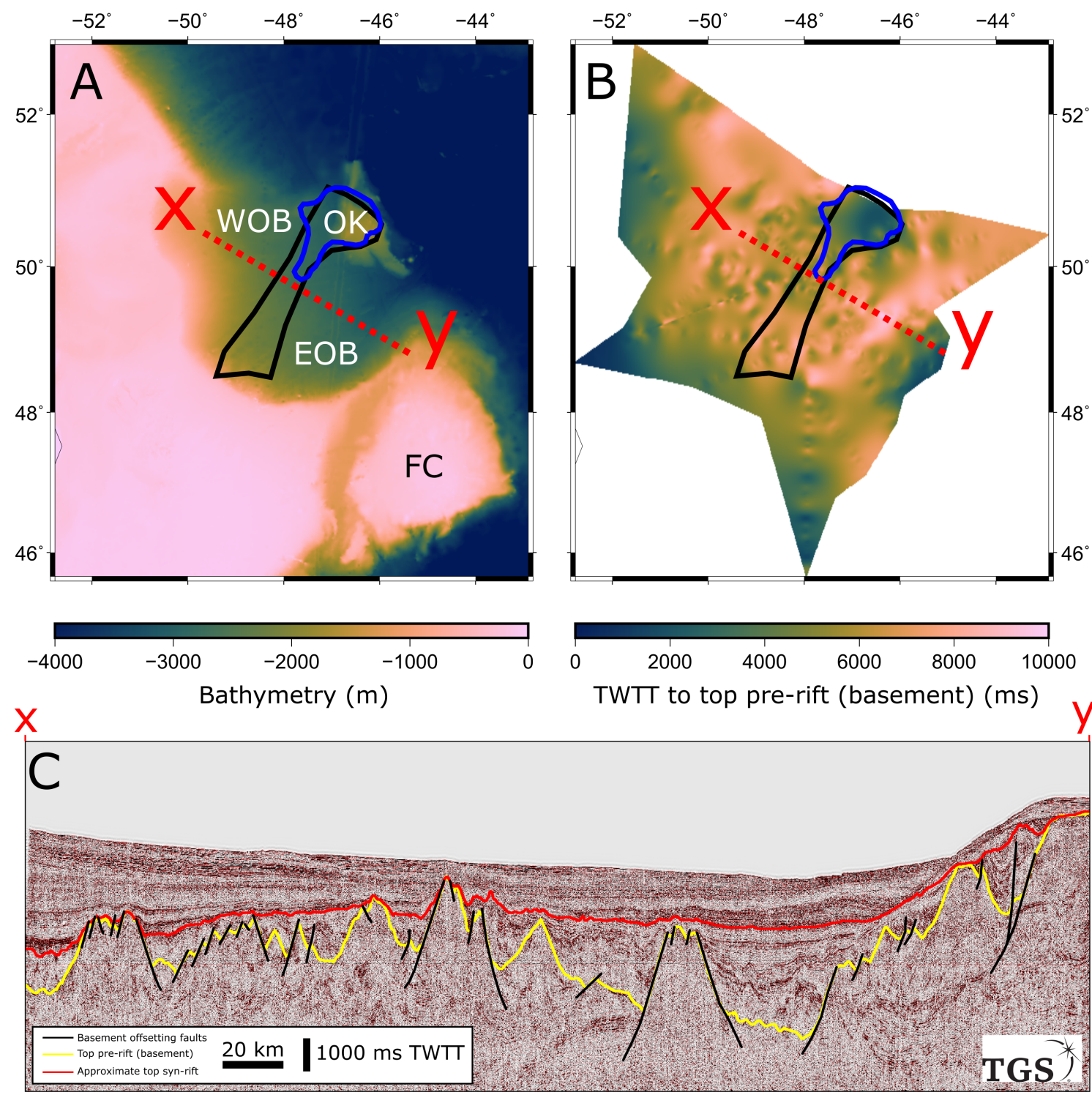

1640 Figure 2

1641 A) Bathymetry of the Orphan Basin (Smith and Sandwell V18.1) overlain by the geometry of 1642 the Orphan Knoll block from Nirrengarten et al. (2018) (black polygon) and the geometry 1643 derived during this study (blue polygon). The geometry shown by the black polygon is used in 1644 Model 2, whilst the geometry shown in blue is used in Models 3 and 6a-d. B) Depth (in two1645 way-travel time, TWTT) to the seismic basement horizon in the Orphan Basin as used to define 1646 a smaller geometry for the Orphan Knoll. C) Representative seismic reflection profile from the 16472001 TGS survey through both the East and West Orphan sub-basins with the top pre-rift 1648 basement horizon shown in yellow (as used to produce the surface in B) and the approximate 1649 top syn-rift horizon in red. We would like to acknowledge TGS for the provision of this data 1650 shown in this figure. $\mathrm{EOB}=$ East Orphan Basin, FC $=$ Flemish Cap, OK = Orphan Knoll and, 1651 WOB $=$ West Orphan Basin. 

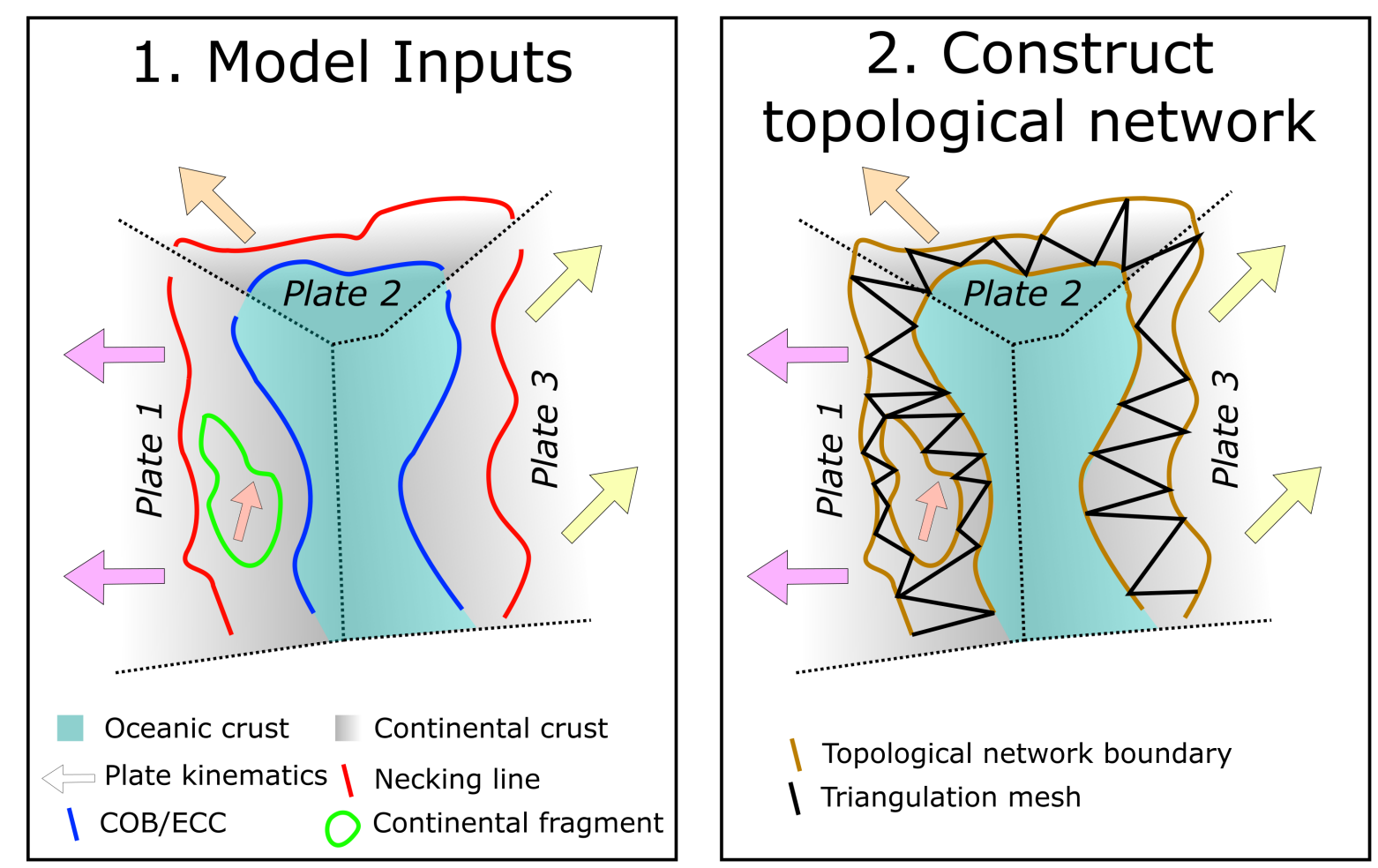

\section{Crustal thickness model}

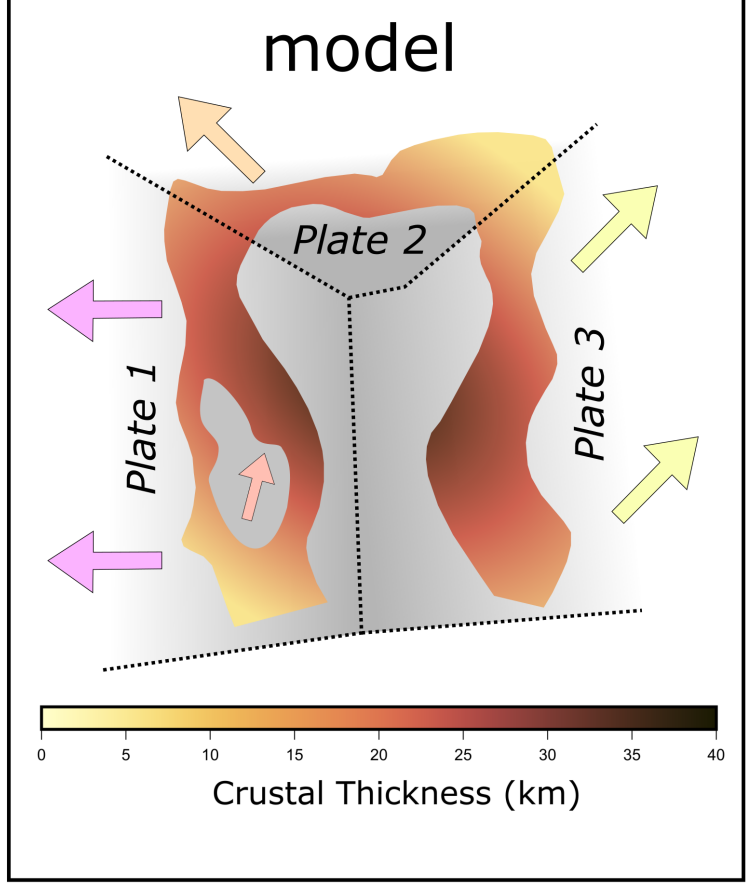

\section{Comparison with independent observations}

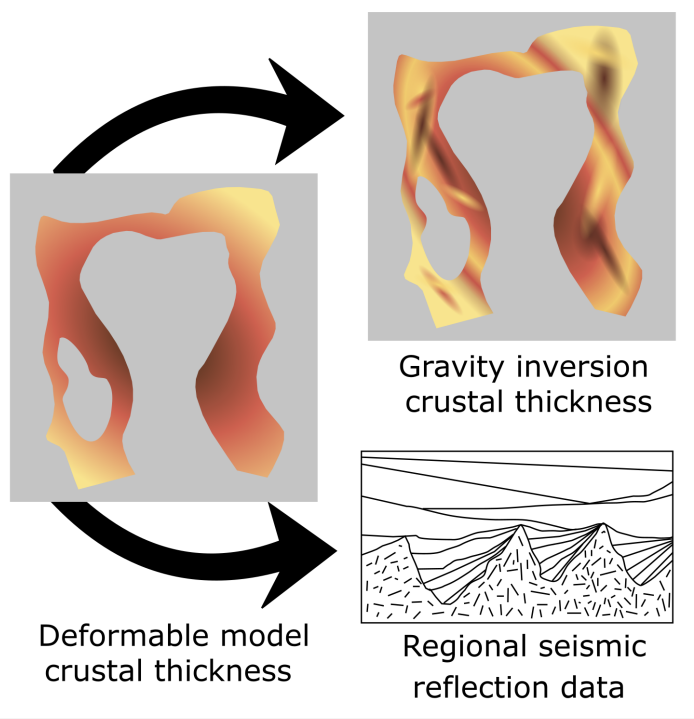

1654 Figure 3

1655 Schematic depiction of the GPlates deformable modelling workflow utilised herein following 1656 the method described in Gurnis et al. (2018). COB = Continent-Ocean boundary, and ECC = 1657 edge of continental crust. 


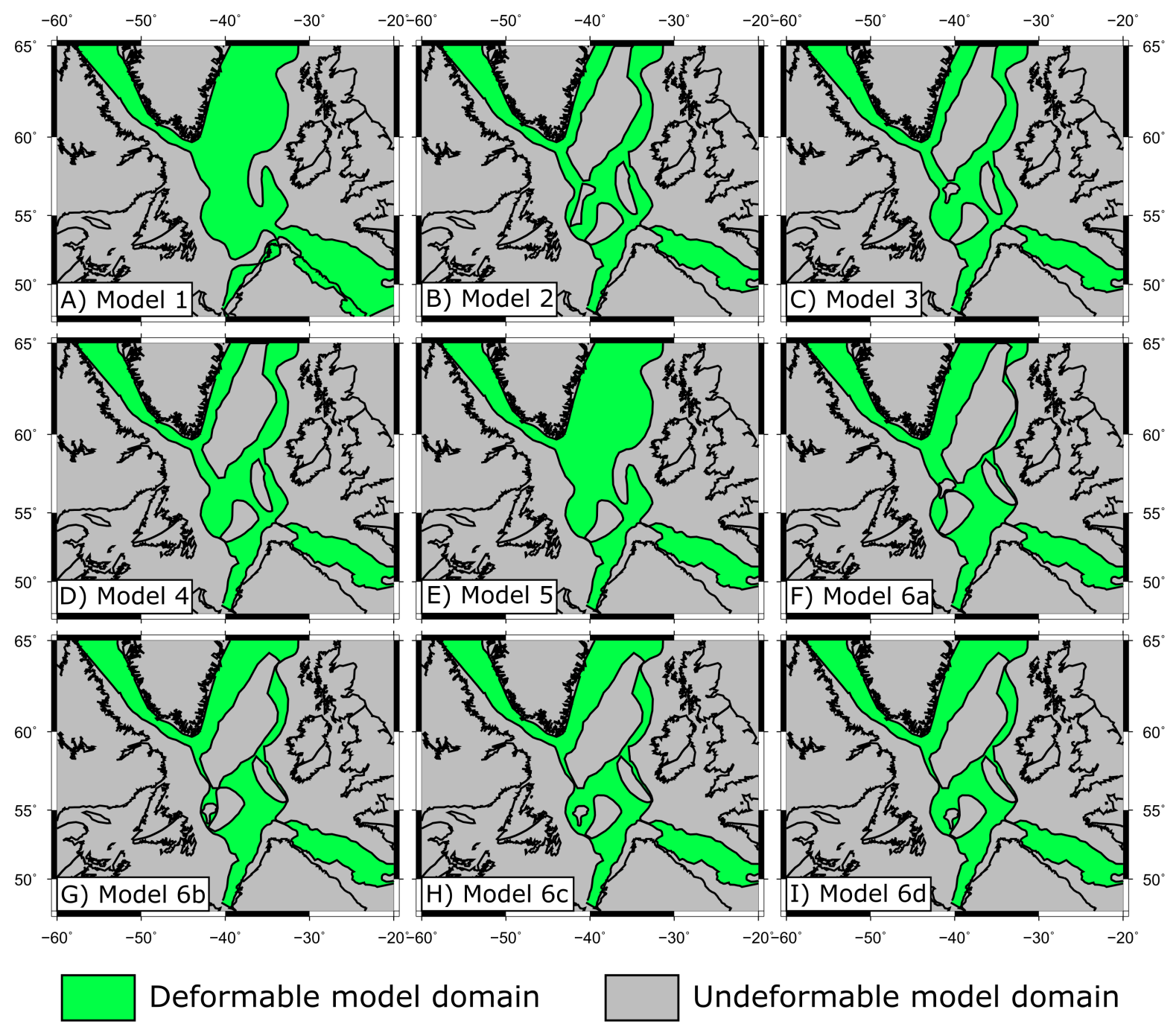

1660 Figure 4

1661 Initial model setup showing the deformable mesh domain in green with uniform, $30 \mathrm{~km}$ thick, 1662 homogeneous crust at 200 Ma for: A) Model 1, B) Model 2, C) Model 3, D) Model 4, E) Model 1663 5, F) Model 6a, G) Model 6b, H) Model 6c and I) Model 6d. The most northern extent of the 1664 modelled domains is slightly greater than shown on this figure but is not included here at it is 1665 beyond the primary region of interest. 


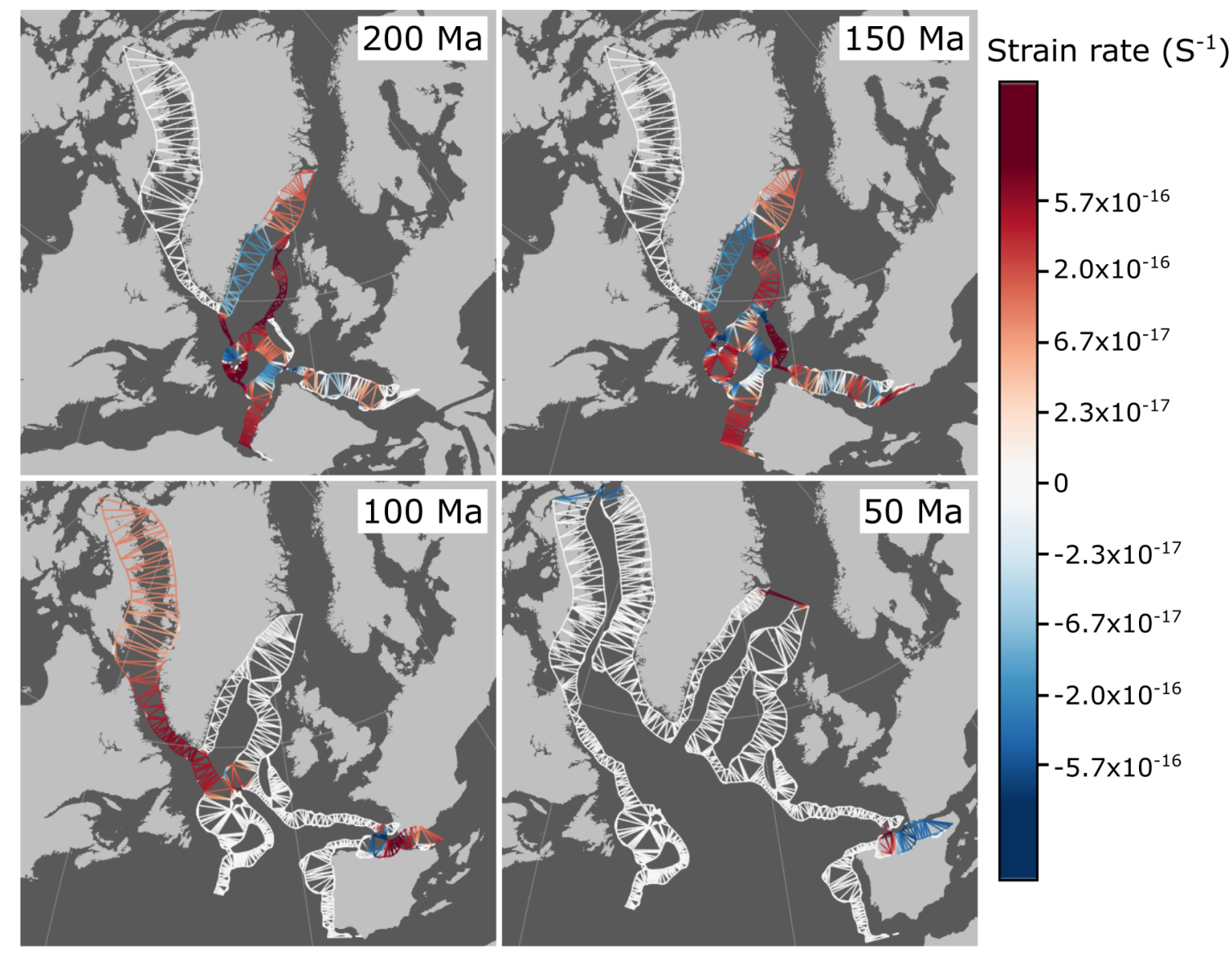

1668 Figure 5 - Evolution of the strain mesh in GPlates used in model 6c, shown with a fixed 1669 Greenland plate at $200 \mathrm{Ma}, 150 \mathrm{Ma}, 100 \mathrm{Ma}$ and $50 \mathrm{Ma}$. The strain mesh in the other models 1670 is of comparable density and distribution. 


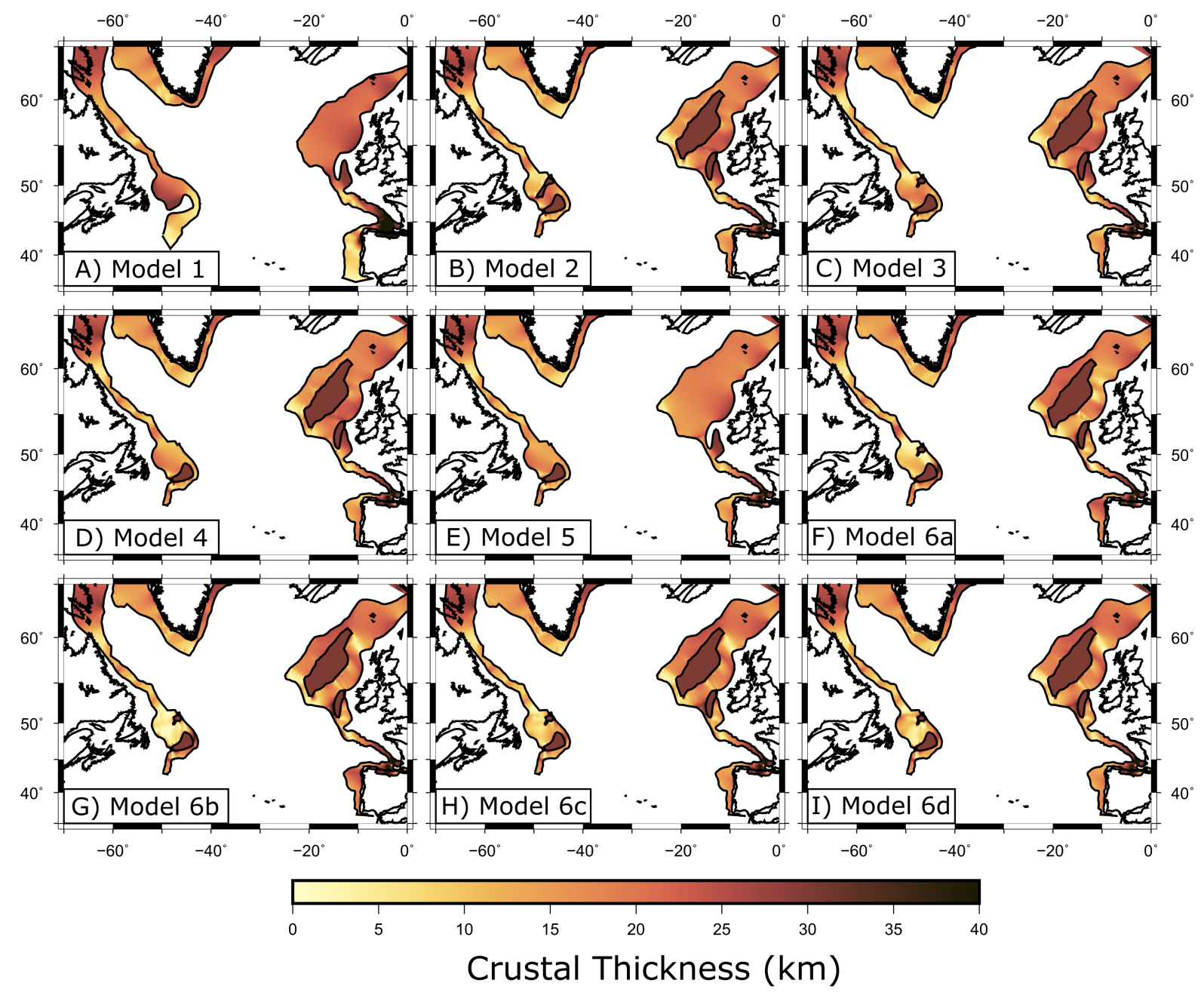

\section{Crustal Thickness (km)}

1672 Figure 6 - Modelled crustal thickness at 0 Ma (present) from A) Model 1, B) Model 2, C) 1673 Model 3, D) Model 4, E) Model 5, F) Model 6a, G) Model 6b, H) Model 6c and I) Model 6d. 


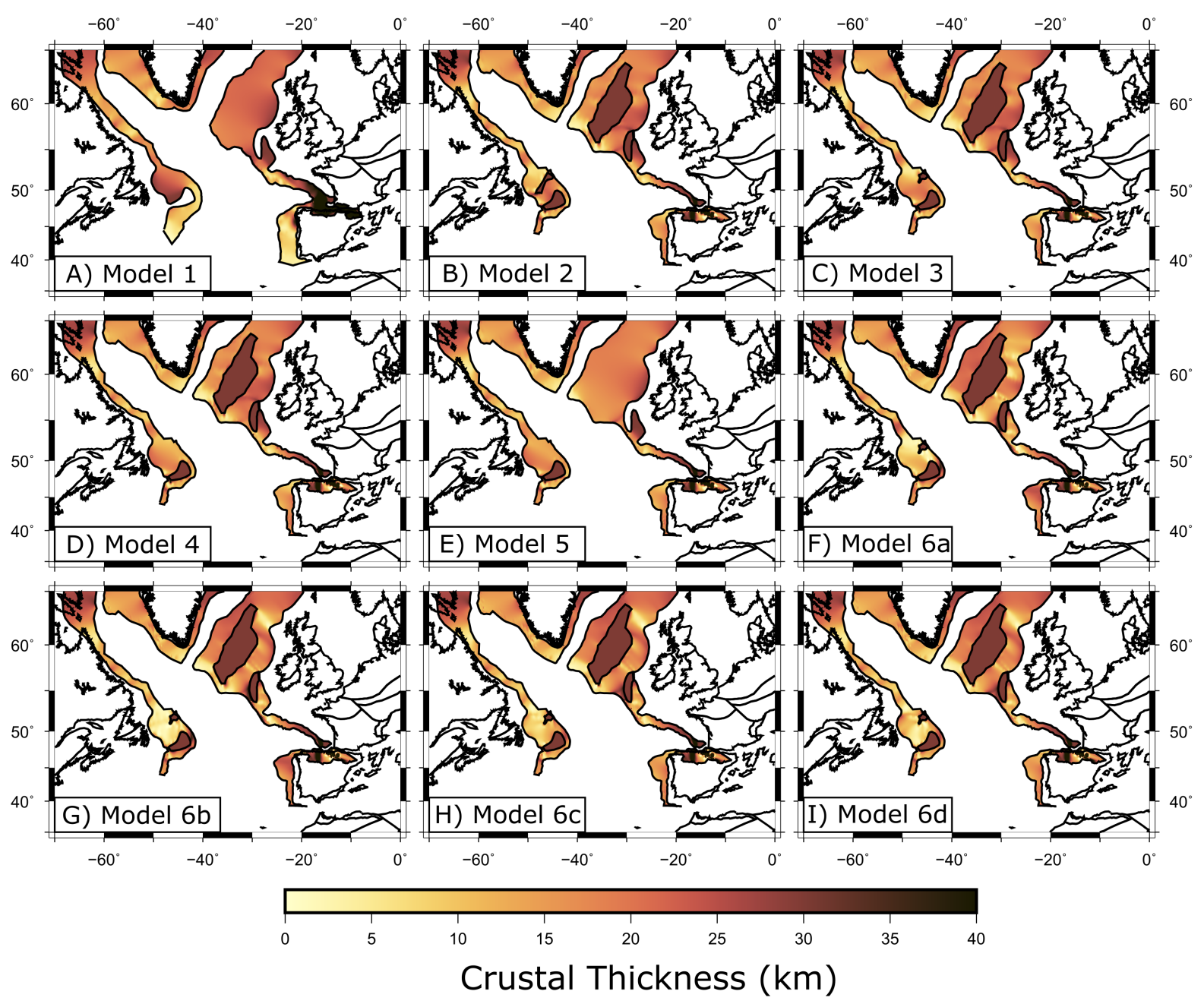

1675 Figure 7 - Modelled crustal thickness at 50 Ma from A) Model 1, B) Model 2, C) Model 3, D) 1676 Model 4, E) Model 5, F) Model 6a, G) Model 6b, H) Model 6c and I) Model 6d. 


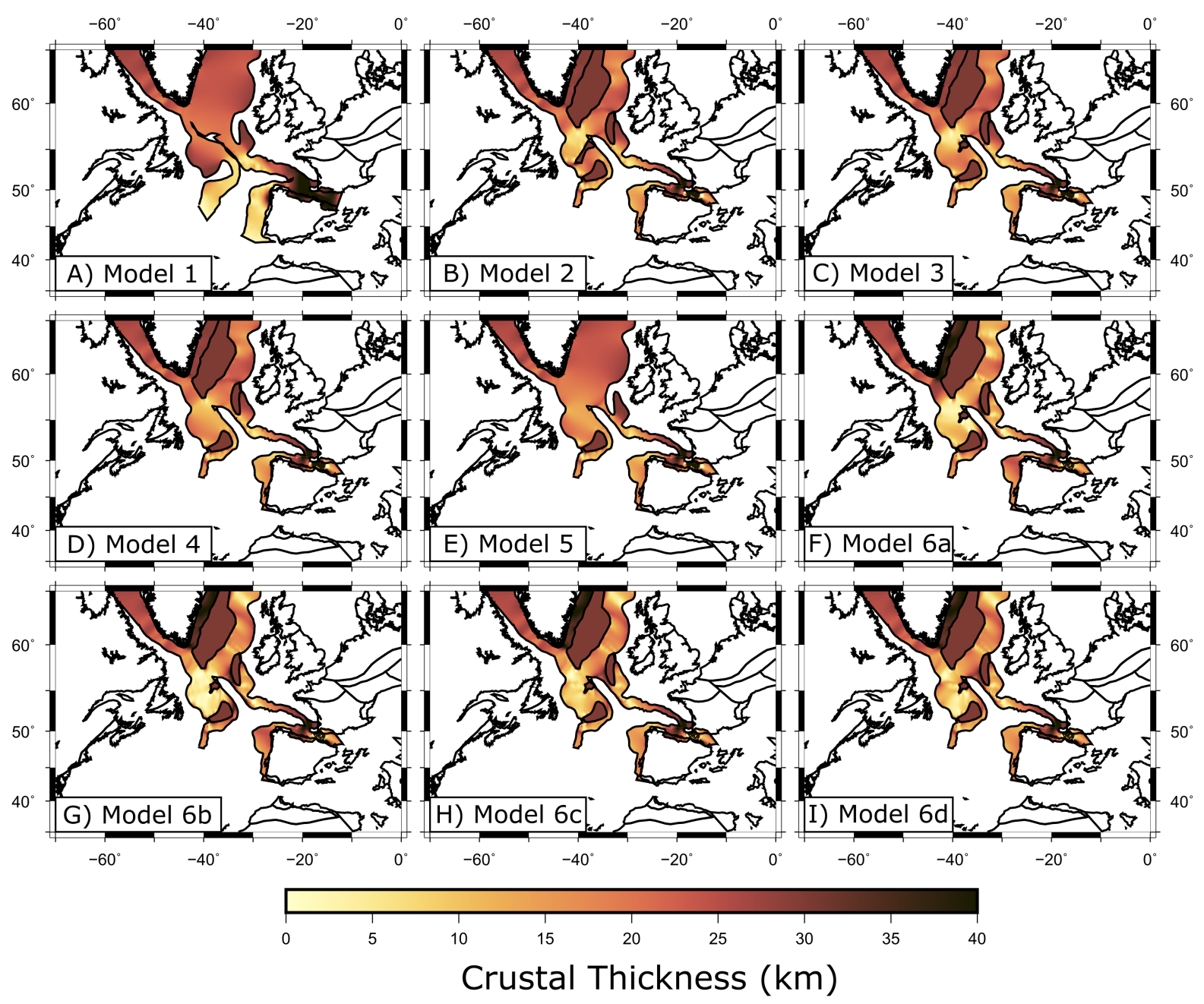

1678 Figure 8 - Modelled crustal thickness at 100 Ma from A) Model 1, B) Model 2, C) Model 3, 1679 D) Model 4, E) Model 5, F) Model 6a, G) Model 6b, H) Model 6c and I) Model 6d. 

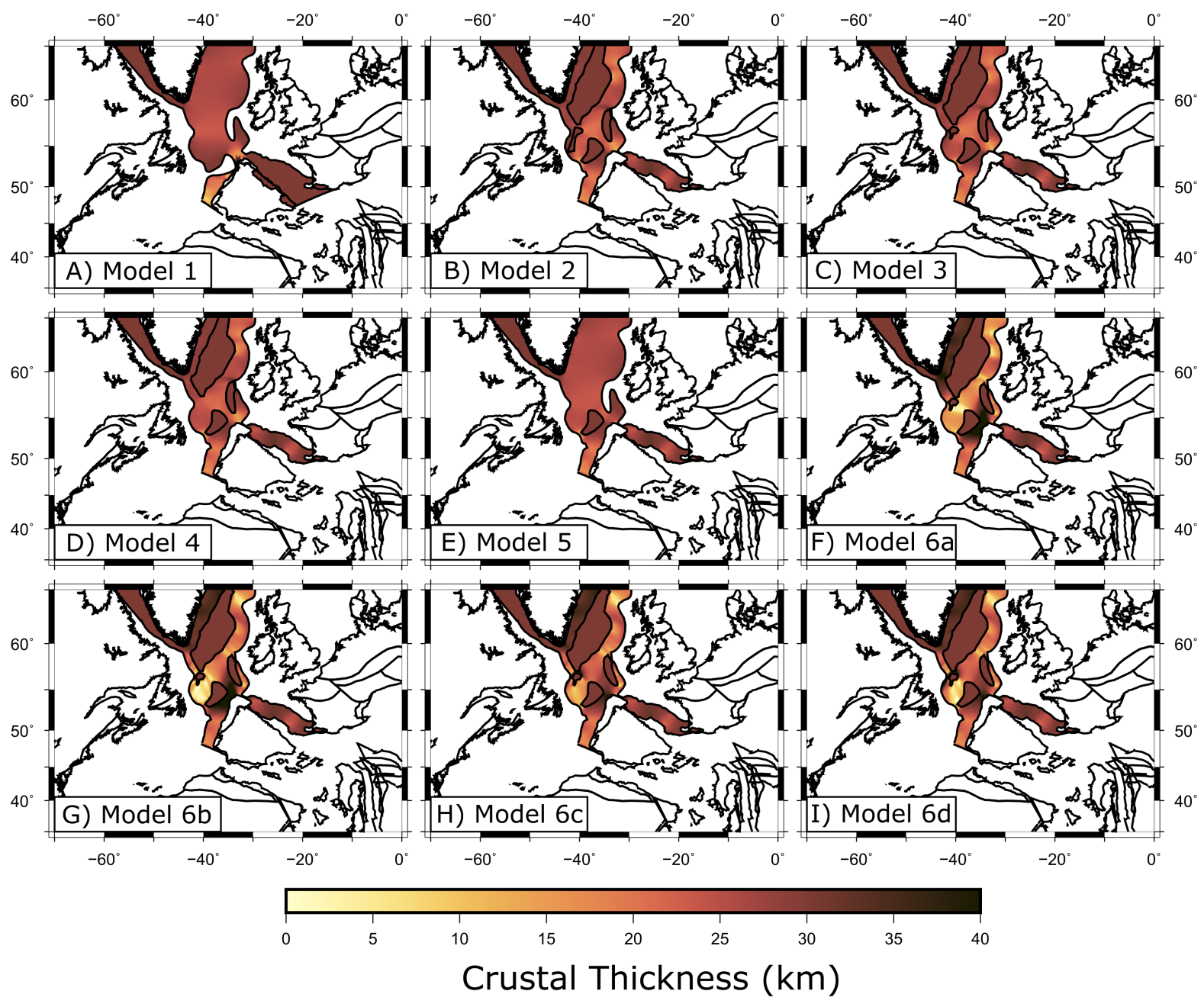

1681 Figure 9 - Modelled crustal thickness at 150 Ma from A) Model 1, B) Model 2, C) Model 3, 1682 D) Model 4, E) Model 5, F) Model 6a, G) Model 6b, H) Model 6c and I) Model 6d. 

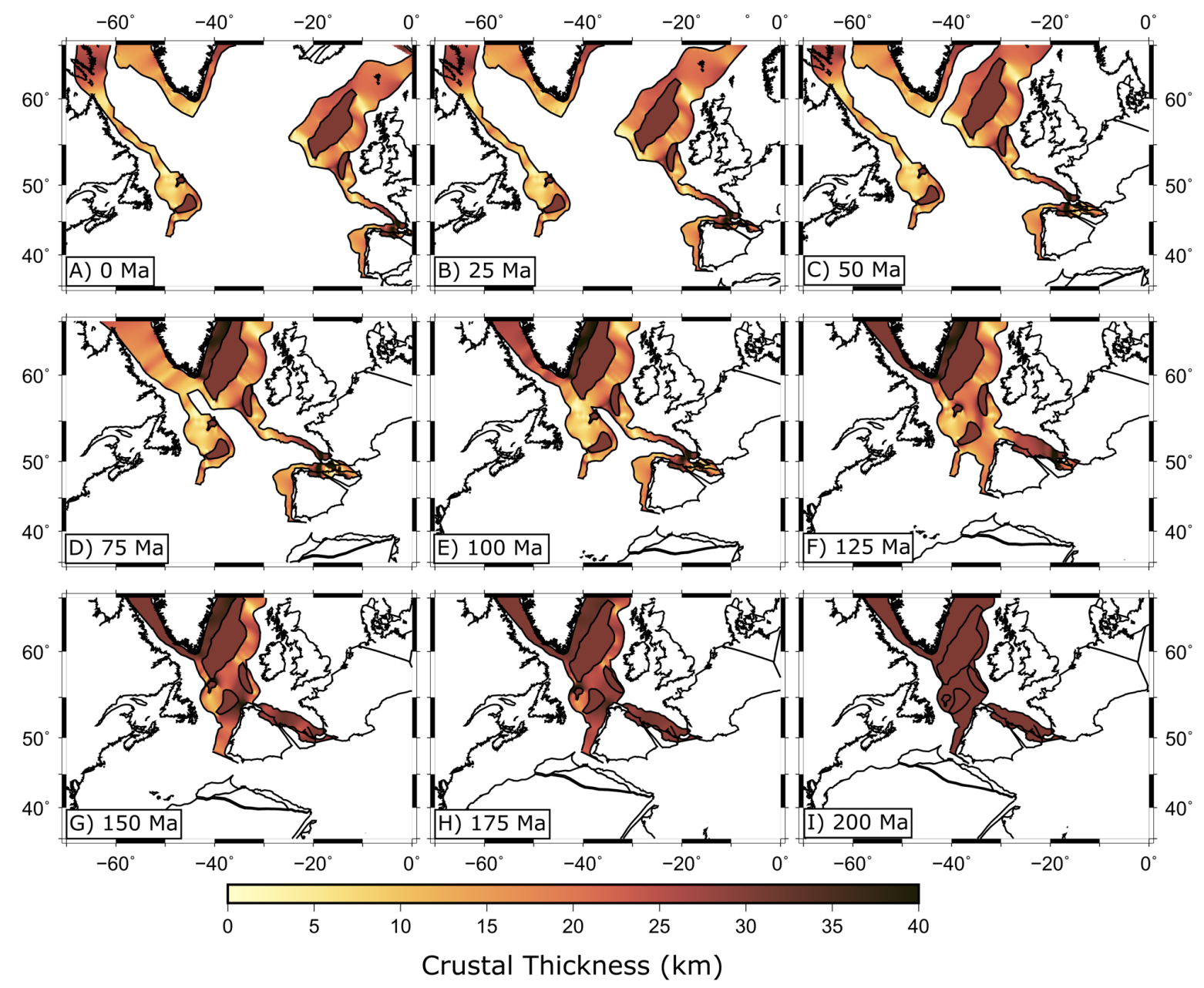

1684 Figure 10 - Temporal evolution of crustal thickness in Model 6c shown at: A) 0 Ma, B) 25 Ma, 1685 C) $50 \mathrm{Ma}$, D) $75 \mathrm{Ma}$, E) $100 \mathrm{Ma}$, F) $125 \mathrm{Ma}$, G) $150 \mathrm{Ma}, \mathrm{H}) 175 \mathrm{Ma}$ and I) $200 \mathrm{Ma}$. 

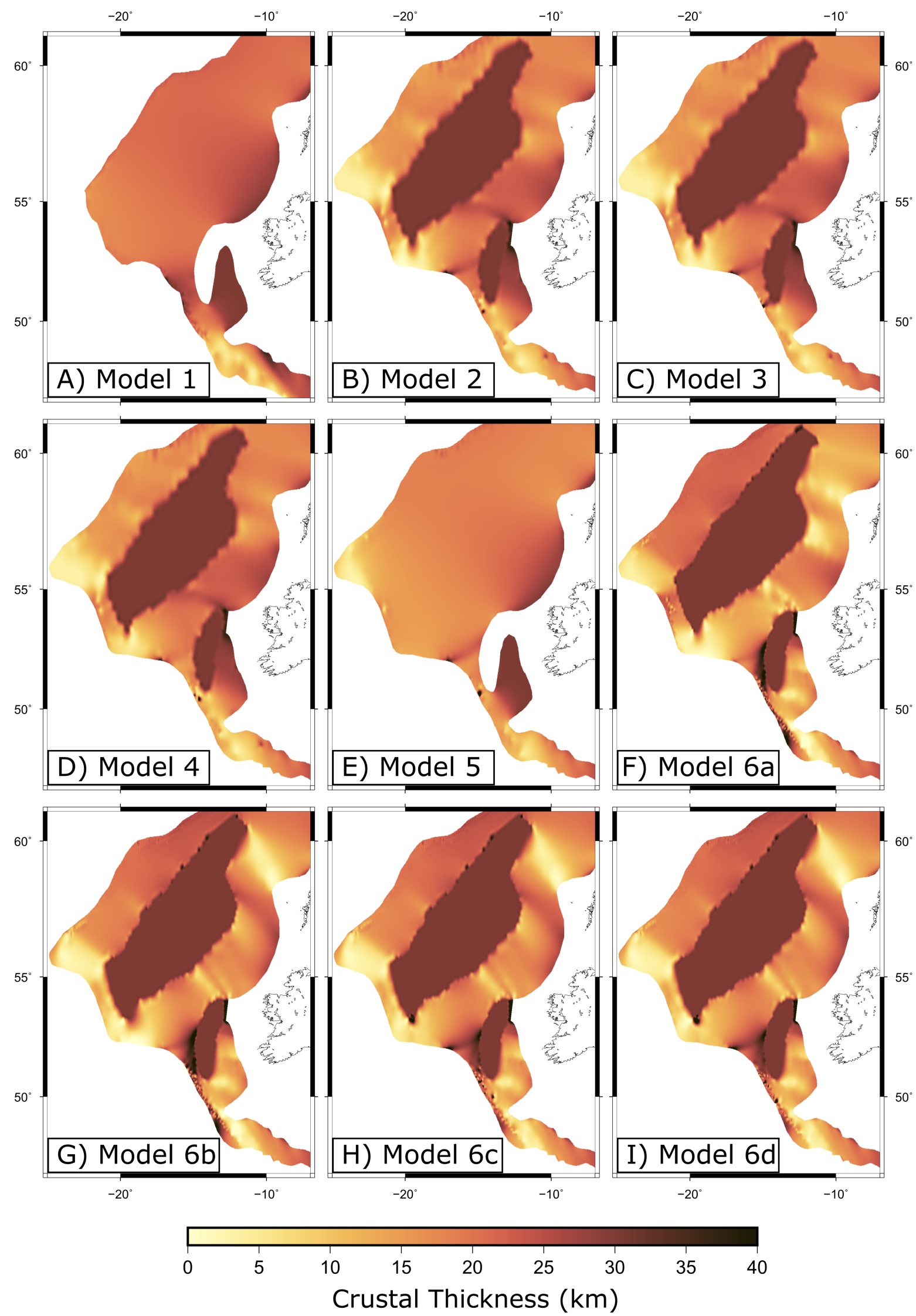

1687 Figure 11 - Irish margin crustal thickness at 0 Ma from A) Model 1, B) Model 2, C) Model 3, 1688 D) Model 4, E) Model 5, F) Model 6a, G) Model 6b, H) Model 6c and I) Model 6d. 


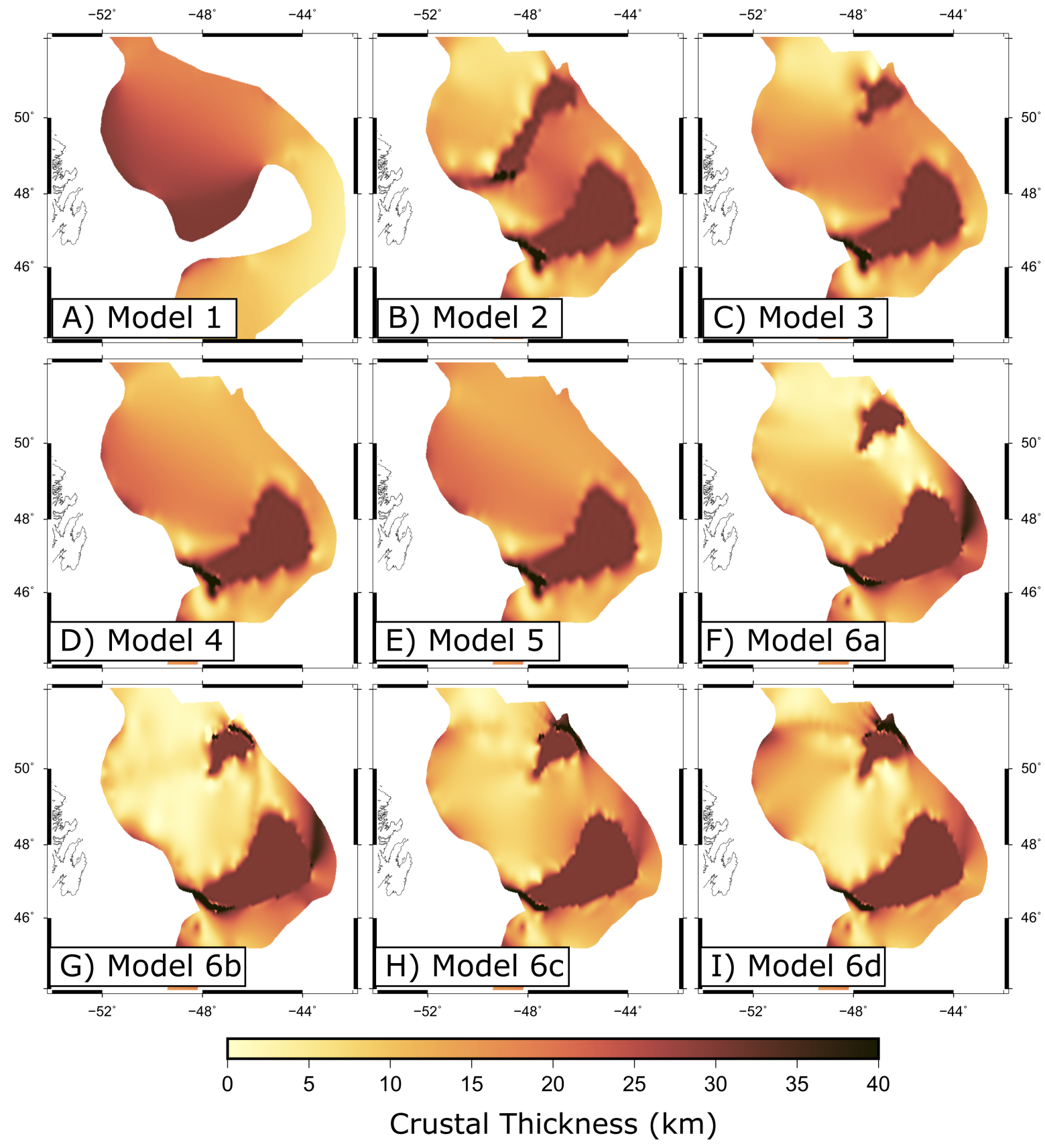

1690 Figure 12 - Newfoundland margin crustal thickness at 0 Ma from A) Model 1, B) Model 2, C) 1691 Model 3, D) Model 4, E) Model 5, F) Model 6a, G) Model 6b, H) Model 6c and I) Model 6d. 

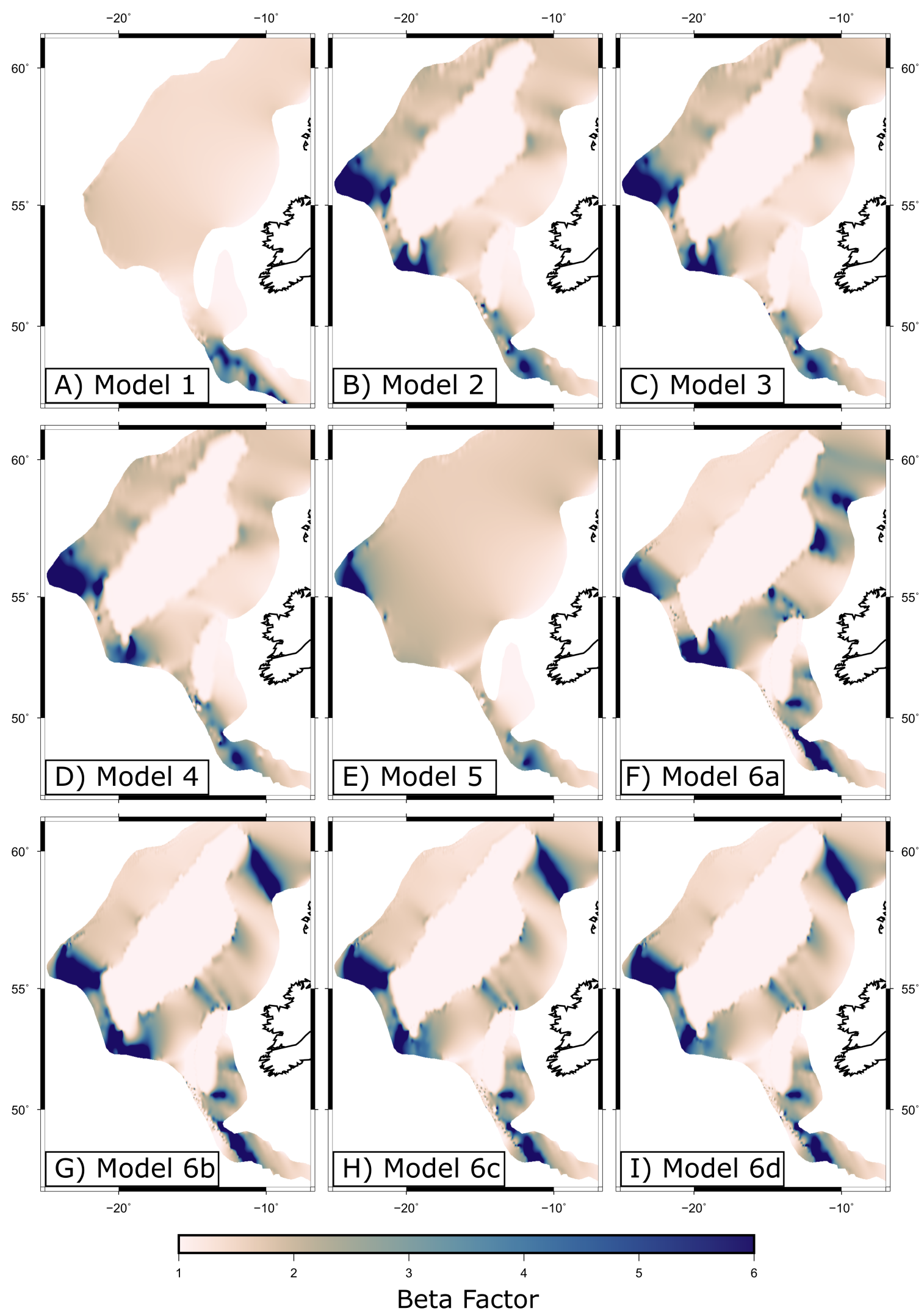

1693 Figure 13 - Irish margin beta factor at 0 Ma from A) Model 1, B) Model 2, C) Model 3, D) 1694 Model 4, E) Model 5, F) Model 6a, G) Model 6b, H) Model 6c and I) Model 6d. The beta factor 1695 data was cropped at 10 for display. 


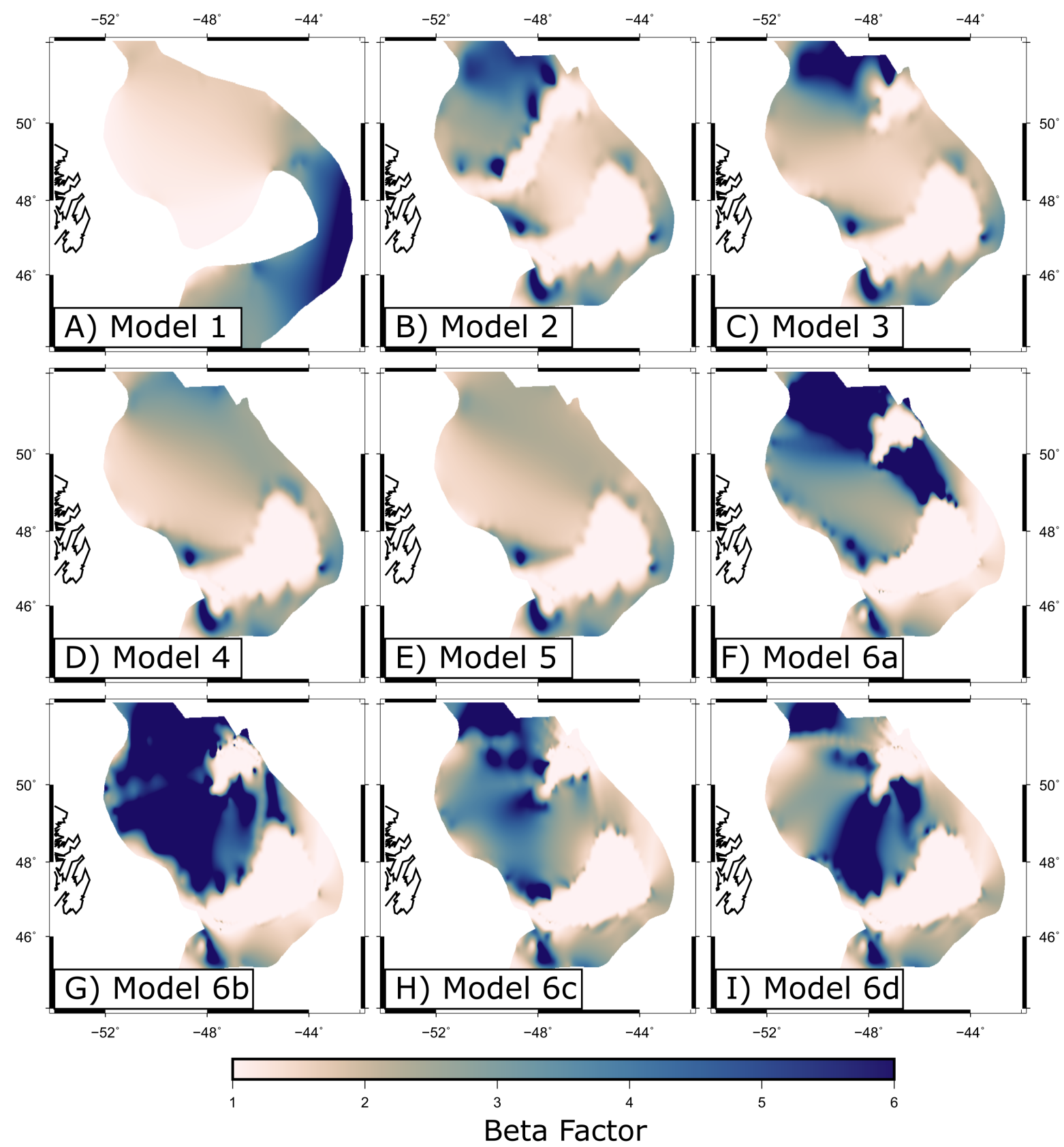

1697 Figure 14 - Newfoundland margin beta factor at 0 Ma from A) Model 1, B) Model 2, C) Model 1698 3, D) Model 4, E) Model 5, F) Model 6a, G) Model 6b, H) Model 6c and I) Model 6d. The beta 1699 factor data was cropped at 10 for display. 


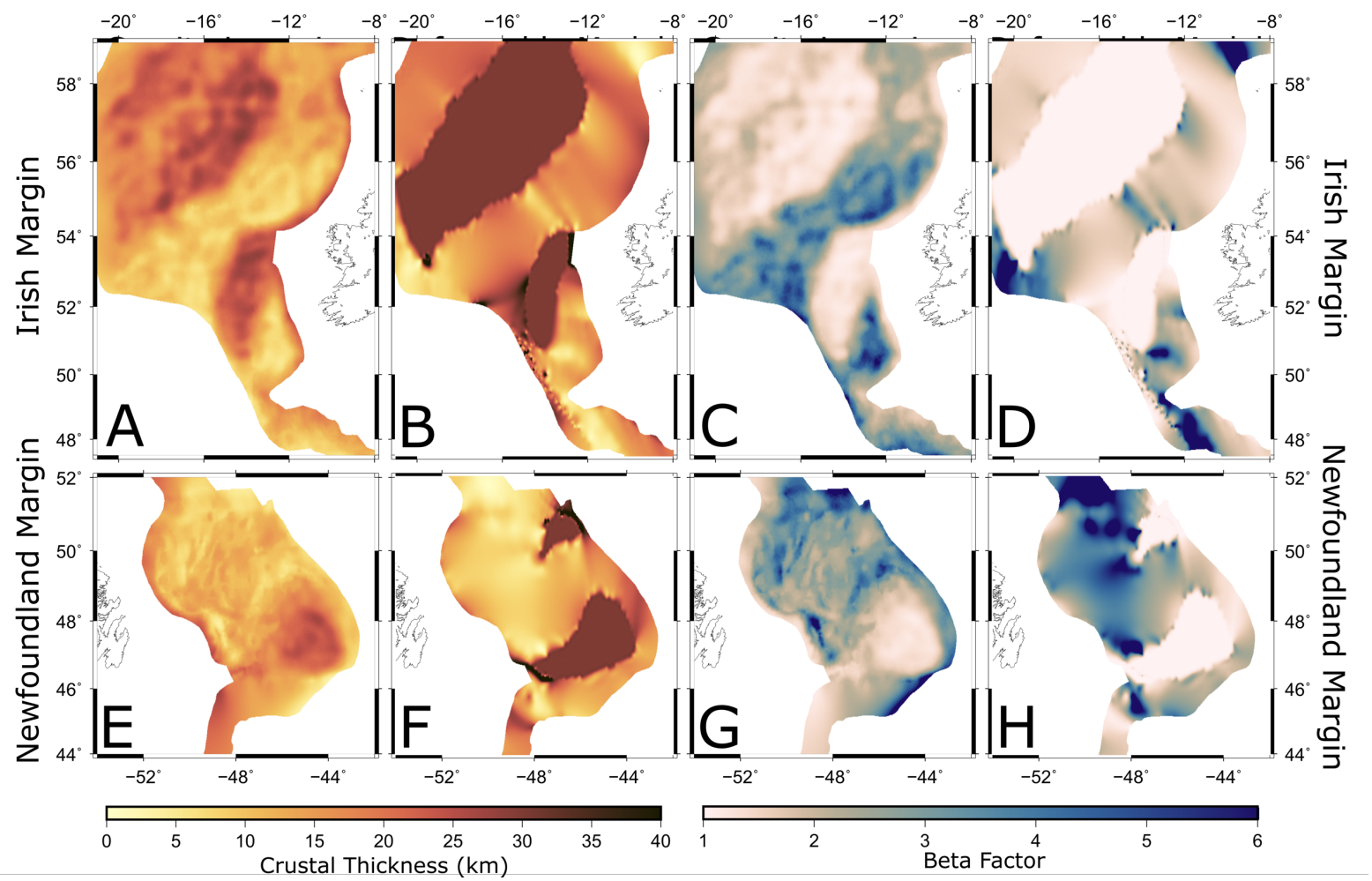
1702 Figure 15 - Irish margin crustal thickness estimate from A) gravity and B) deformable GPlates
1703 model 6c and beta factor from C) gravity inversion and D) deformable GPlates models. 1704 Newfoundland margin crustal thickness estimate from E) gravity inversion and F) deformable 1705 GPlates model $6 \mathrm{c}$ and beta factor from $\mathrm{G}$ ) gravity inversion and $\mathrm{H}$ ) deformable GPlates model 1706 6c. The gravity inversion for crustal thickness is from Welford et al. (2012). Beta factors were 1707 calculated based on a pre-deformation thickness of $30 \mathrm{~km}$. The beta factor data was cropped at 170810 for display. 


\begin{tabular}{|c|c|c|c|c|c|c|}
\hline Model \# & 1 & 2 & 3 & 4 & 5 & 6a-d \\
\hline $\begin{array}{l}\text { Inner } \\
\text { Boundary }\end{array}$ & $\begin{array}{l}\text { Müller et al. } \\
\text { (2016) COBs }\end{array}$ & $\begin{array}{l}\text { Nirrengarten } \\
\text { et al. (2018) } \\
\text { ECC }\end{array}$ & $\begin{array}{l}\text { Nirrengarten } \\
\text { et al. (2018) } \\
\text { ECC }\end{array}$ & $\begin{array}{l}\text { Nirrengarten } \\
\text { et al. (2018) } \\
\text { ECC }\end{array}$ & $\begin{array}{l}\text { Nirrengarten } \\
\text { et al. (2018) } \\
\text { ECC }\end{array}$ & $\begin{array}{l}\text { Nirrengarten } \\
\text { et al. (2018) } \\
\text { ECC }\end{array}$ \\
\hline $\begin{array}{l}\text { Main Outer } \\
\text { Boundary }\end{array}$ & $\begin{array}{l}\text { Nirrengarten } \\
\text { et al. (2018) } \\
\text { Necking } \\
\text { Zone } \\
\text { (Modified) }\end{array}$ & $\begin{array}{l}\text { Nirrengarten } \\
\text { et al. (2018) } \\
\text { Necking } \\
\text { Zone } \\
\text { (Modified) }\end{array}$ & $\begin{array}{l}\text { Nirrengarten } \\
\text { et al. (2018) } \\
\text { Necking } \\
\text { Zone } \\
\text { (Modified) }\end{array}$ & $\begin{array}{l}\text { Nirrengarten } \\
\text { et al. (2018) } \\
\text { Necking } \\
\text { Zone } \\
\text { (Modified) }\end{array}$ & $\begin{array}{l}\text { Nirrengarten } \\
\text { et al. (2018) } \\
\text { Necking } \\
\text { Zone } \\
\text { (Modified) }\end{array}$ & $\begin{array}{l}\text { Nirrengarten } \\
\text { et al. (2018) } \\
\text { Necking } \\
\text { Zone } \\
\text { (Modified) }\end{array}$ \\
\hline & & $\begin{array}{l}\text { Nirrengarten } \\
\text { et al. (2018) }\end{array}$ & $\begin{array}{l}\text { Nirrengarten } \\
\text { et al. (2018) }\end{array}$ & $\begin{array}{l}\text { Nirrengarten } \\
\text { et al. (2018) }\end{array}$ & $\begin{array}{l}\text { Nirrengarten } \\
\text { et al. (2018) }\end{array}$ & $\begin{array}{l}\text { Nirrengarten } \\
\text { et al. (2018) }\end{array}$ \\
\hline $\begin{array}{l}\text { Breakup } \\
\text { defined by }\end{array}$ & $\begin{array}{l}\text { Müller et al. } \\
\text { (2016) COBs } \\
\text { appearance }\end{array}$ & $\begin{array}{l}\text { ECC no } \\
\text { longer } \\
\text { overlapping }\end{array}$ & $\begin{array}{l}\text { ECC no } \\
\text { longer } \\
\text { overlapping }\end{array}$ & $\begin{array}{l}\text { ECC no } \\
\text { longer } \\
\text { overlapping }\end{array}$ & $\begin{array}{l}\text { ECC no } \\
\text { longer } \\
\text { overlapping }\end{array}$ & $\begin{array}{l}\text { ECC no } \\
\text { longer } \\
\text { overlapping }\end{array}$ \\
\hline $\begin{array}{l}\text { Orphan } \\
\text { Knoll }\end{array}$ & Not included & $\begin{array}{l}\text { Separate } \\
\text { Plate }\end{array}$ & $\begin{array}{l}\text { Separate } \\
\text { Plate with } \\
\text { geometry } \\
\text { from seismic } \\
\text { basement } \\
\text { (Fig. 2) }\end{array}$ & Not included & Not included & $\begin{array}{l}\text { Separate } \\
\text { Plate with } \\
\text { geometry } \\
\text { from seismic } \\
\text { basement } \\
\text { (Fig. 2) }\end{array}$ \\
\hline Flemish Cap & $\begin{array}{l}\text { Not a } \\
\text { separate } \\
\text { plate, part of } \\
\text { NAM }\end{array}$ & $\begin{array}{l}\text { Separate } \\
\text { Plate }\end{array}$ & $\begin{array}{l}\text { Separate } \\
\text { Plate }\end{array}$ & $\begin{array}{l}\text { Separate } \\
\text { Plate }\end{array}$ & $\begin{array}{l}\text { Separate } \\
\text { Plate }\end{array}$ & $\begin{array}{l}\text { Separate } \\
\text { Plate }\end{array}$ \\
\hline Hatton Bank & Not included & $\begin{array}{l}\text { Separate } \\
\text { Plate }\end{array}$ & $\begin{array}{l}\text { Separate } \\
\text { Plate }\end{array}$ & $\begin{array}{l}\text { Separate } \\
\text { Plate }\end{array}$ & Not included & $\begin{array}{l}\text { Separate } \\
\text { Plate }\end{array}$ \\
\hline $\begin{array}{l}\text { Porcupine } \\
\text { Bank }\end{array}$ & $\begin{array}{l}\text { Not a } \\
\text { separate } \\
\text { plate, part of } \\
\text { EUR }\end{array}$ & $\begin{array}{l}\text { Separate } \\
\text { Plate }\end{array}$ & $\begin{array}{l}\text { Separate } \\
\text { Plate }\end{array}$ & $\begin{array}{l}\text { Separate } \\
\text { Plate }\end{array}$ & Not included & $\begin{array}{l}\text { Separate } \\
\text { Plate with } \\
\text { new } \\
\text { calculated } \\
\text { pole }\end{array}$ \\
\hline $\begin{array}{ll}\text { Davis } & \text { Strait } \\
\text { and } & \text { Baffin } \\
\text { Bay } & \\
\end{array}$ & $\begin{array}{l}\text { Welford et al. } \\
\text { (2018) }\end{array}$ & $\begin{array}{l}\text { Welford et al. } \\
\text { (2018) }\end{array}$ & $\begin{array}{l}\text { Welford et al. } \\
\text { (2018) }\end{array}$ & $\begin{array}{l}\text { Welford et al. } \\
(2018)\end{array}$ & $\begin{array}{l}\text { Welford et al. } \\
\text { (2018) }\end{array}$ & $\begin{array}{l}\text { Welford et al. } \\
\text { (2018) }\end{array}$ \\
\hline $\begin{array}{l}\text { Poles of } \\
\text { rotation }\end{array}$ & $\begin{array}{l}\text { Matthews et } \\
\text { al. (2016) }\end{array}$ & $\begin{array}{l}\text { Nirrengarten } \\
\text { et al. (2018) }\end{array}$ & $\begin{array}{l}\text { Nirrengarten } \\
\text { et al. (2018) }\end{array}$ & $\begin{array}{l}\text { Nirrengarten } \\
\text { et al. (2018) }\end{array}$ & $\begin{array}{l}\text { Nirrengarten } \\
\text { et al. (2018) }\end{array}$ & $\begin{array}{l}\text { This study } \\
\text { (tables } 2 \mathrm{a}-\mathrm{d} \text { ) } \\
\text { after } \\
\text { Nirrengarten } \\
\text { et al. (2018) }\end{array}$ \\
\hline Start time & $200 \mathrm{Ma}$ & $200 \mathrm{Ma}$ & $200 \mathrm{Ma}$ & $200 \mathrm{Ma}$ & $200 \mathrm{Ma}$ & $200 \mathrm{Ma}$ \\
\hline $\begin{array}{l}\text { Original } \\
\text { Crustal } \\
\text { thickness }\end{array}$ & $30 \mathrm{~km}$ & $30 \mathrm{~km}$ & $30 \mathrm{~km}$ & $30 \mathrm{~km}$ & $30 \mathrm{~km}$ & $30 \mathrm{~km}$ \\
\hline
\end{tabular}

1712 Table 1

1713 The components used in Models 1-6(a-d). NAM = North America and EUR = Eurasia. 


\begin{tabular}{|c|c|c|c|c|}
\hline Age & Latitude & Longitude & Angle & Fixed Plate \\
\hline \multicolumn{5}{|c|}{ Porcupine Bank } \\
\hline 200 & 53.1758 & -11.3586 & 35.4255 & EUR \\
\hline 160 & 0 & 0 & 0 & EUR \\
\hline \multicolumn{5}{|c|}{$\begin{array}{l}\text { Rockall-Hatton } \\
\text { Bank }\end{array}$} \\
\hline 200 & 51.6692 & 123.233 & -12.4267 & GRN \\
\hline 120 & 50.17 & 120.8 & -12.88 & GRN \\
\hline 120 & 0 & 0 & 0 & EUR \\
\hline \multicolumn{5}{|c|}{ Flemish Cap } \\
\hline 200 & 60.1646 & -23.7406 & 77.8799 & IB \\
\hline 160 & 63.94 & -20.84 & 69.15 & IB \\
\hline 160 & 44.65 & -54.79 & 18.83 & NAM \\
\hline 140 & 45.28 & -53.47 & 20.03 & NAM \\
\hline 112 & 0 & 0 & 0 & NAM \\
\hline \multicolumn{5}{|c|}{ Orphan Knoll } \\
\hline 200 & 20.8225 & -62.6855 & 4.4293 & NAM \\
\hline 140 & 42.38 & -54 & 12.56 & NAM \\
\hline 130 & 44.97 & -52.57 & 13.2 & NAM \\
\hline 112 & 0 & 0 & 0 & NAM \\
\hline
\end{tabular}

\section{Table $2 \mathrm{a}$}

1716 Poles of rotation used in Model 6a. All poles not listed are identical to Nirrengarten et al. 1717 (2018).

1718 


\begin{tabular}{|c|c|c|c|c|}
\hline Age & Latitude & Longitude & Angle & Fixed Plate \\
\hline \multicolumn{5}{|c|}{ Porcupine Bank } \\
\hline 200 & 53.1758 & -11.3586 & 35.4255 & EUR \\
\hline 160 & 0 & 0 & 0 & EUR \\
\hline \multicolumn{5}{|c|}{$\begin{array}{l}\text { Rockall-Hatton } \\
\text { Bank }\end{array}$} \\
\hline 200 & 73.3464 & 110.659 & -16.8172 & GRN \\
\hline 120 & 50.17 & 120.8 & -12.88 & GRN \\
\hline 120 & 0 & 0 & 0 & EUR \\
\hline \multicolumn{5}{|c|}{ Flemish Cap } \\
\hline 200 & 61.4116 & -23.4066 & 74.9163 & IB \\
\hline 160 & 63.94 & -20.84 & 69.15 & IB \\
\hline 160 & 44.65 & -54.79 & 18.83 & NAM \\
\hline 140 & 45.28 & -53.47 & 20.03 & NAM \\
\hline 112 & 0 & 0 & 0 & NAM \\
\hline \multicolumn{5}{|c|}{ Orphan Knoll } \\
\hline 200 & 44.2801 & -46.6569 & 26.1169 & NAM \\
\hline 140 & 42.38 & -54 & 12.56 & NAM \\
\hline 130 & 44.97 & -52.57 & 13.2 & NAM \\
\hline 112 & 0 & 0 & 0 & NAM \\
\hline
\end{tabular}

1719

1720 Table $2 b$

1721 Poles of rotation used in Model 6b. All poles not listed are identical to Nirrengarten et al. 1722 (2018).

1723 


\begin{tabular}{|c|c|c|c|c|}
\hline Age & Latitude & Longitude & Angle & Fixed Plate \\
\hline \multicolumn{5}{|c|}{ Porcupine Bank } \\
\hline 200 & 53.1758 & -11.3586 & 35.4255 & EUR \\
\hline 160 & 0 & 0 & 0 & EUR \\
\hline \multicolumn{5}{|c|}{$\begin{array}{l}\text { Rockall-Hatton } \\
\text { Bank }\end{array}$} \\
\hline 200 & 73.3464 & 110.659 & -16.8172 & GRN \\
\hline 120 & 50.17 & 120.8 & -12.88 & GRN \\
\hline 120 & 0 & 0 & 0 & EUR \\
\hline \multicolumn{5}{|c|}{ Flemish Cap } \\
\hline 200 & 62.0046 & -22.3429 & 75.2174 & IB \\
\hline 160 & 63.94 & -20.84 & 69.15 & IB \\
\hline 160 & 44.65 & -54.79 & 18.83 & NAM \\
\hline 140 & 45.28 & -53.47 & 20.03 & NAM \\
\hline 112 & 0 & 0 & 0 & NAM \\
\hline \multicolumn{5}{|c|}{ Orphan Knoll } \\
\hline 200 & 45.1194 & -45.79 & 26.0864 & NAM \\
\hline 140 & 42.38 & -54 & 12.56 & NAM \\
\hline 130 & 44.97 & -52.57 & 13.2 & NAM \\
\hline 112 & 0 & 0 & 0 & NAM \\
\hline
\end{tabular}

1725 Table 2c

1726 Poles of rotation used in Model 6c. All poles not listed are identical to Nirrengarten et al. 1727 (2018).

1728 


\begin{tabular}{|c|c|c|c|c|}
\hline Age & Latitude & Longitude & Angle & Fixed Plate \\
\hline \multicolumn{5}{|c|}{ Porcupine Bank } \\
\hline 200 & 53.1758 & -11.3586 & 35.4255 & EUR \\
\hline 160 & 0 & 0 & 0 & EUR \\
\hline \multicolumn{5}{|c|}{$\begin{array}{l}\text { Rockall-Hatton } \\
\text { Bank }\end{array}$} \\
\hline 200 & 51.6692 & 123.233 & -12.4267 & GRN \\
\hline 120 & 50.17 & 120.8 & -12.88 & GRN \\
\hline 120 & 0 & 0 & 0 & EUR \\
\hline \multicolumn{5}{|c|}{ Flemish Cap } \\
\hline 200 & 62.0046 & -22.3429 & 75.2174 & IB \\
\hline 160 & 63.94 & -20.84 & 69.15 & IB \\
\hline 160 & 44.65 & -54.79 & 18.83 & NAM \\
\hline 140 & 45.28 & -53.47 & 20.03 & NAM \\
\hline 112 & 0 & 0 & 0 & NAM \\
\hline \multicolumn{5}{|c|}{ Orphan Knoll } \\
\hline 200 & 46.7381 & -45.4488 & 32.4638 & NAM \\
\hline 140 & 42.38 & -54 & 12.56 & NAM \\
\hline 130 & 44.97 & -52.57 & 13.2 & NAM \\
\hline 112 & 0 & 0 & 0 & NAM \\
\hline
\end{tabular}

1729

1730 Table 2d

1731 Poles of rotation used in Model 6d. All poles not listed are identical to Nirrengarten et al. 1732 (2018).

1733 